\title{
OZDOBNÝ SPEV SLOVÁKOV V STAREJ PAZOVE (SRBSKO): DOKUMENTÁCIA, TRANSKRIPCIA, ANALÝZA, INTERPRETÁCIA
}

\section{KRISTINA LOMEN}

Mgr. art. Kristina Lomen, PhD.; Ústav hudobnej vedy SAV, Dúbravská cesta 9, 841 04, Bratislava 4; e-mail: kristina.lomen@savba.sk

ORCID: 0000-0003-2166-6875

\section{Abstract}

\begin{abstract}
The employment of ornaments in the traditional singing of Slovaks in the Stara Pazova locality (Vojvodina, Serbia) is a rare phenomenon, and not only in terms of traditional song culture from the territory of Slovakia. It is unusual also in comparison with other Slovak localities in Vojvodina, where it scarcely ever occurs at the present time. This article offers a survey of the history of documentation of embellished singing in Stará Pazova, as well as the representation and occurrence of ornaments in the particular musical style layers in this locality's song repertoire. A basic typology of ornaments is proposed, and three styles of embellished singing are characterised, while attention is also drawn to the importance of the performance aspect. In conclusion, there is a summary account of the hypotheses offered hitherto on the origin of embellished singing in this locality, to which the author adds another based on her current research.
\end{abstract}

Key words: folk song, ethnic enclave, local repertoire, embellished singing, styles, performance practice

Ozdobný spev v lokalite Stará Pazova bezpochyby patrí k ojedinelému javu, s akým sa $\mathrm{v}$ súčasnosti môžeme stretnút v tradičnom piesňovom repertoári Slovákov vo Vojvodine. Zároveň je špecifický aj v kontexte tradičnej piesňovej kultúry z územia dnešného Slovenska. Ozdobnost je jedným zo základných atribútov slovenských pazovských tradičných piesní. Miestni obyvatelia takýto spev nazývajú vikrúcaňia - spevák pri interpretácii piesní vikrúca. Uvedený fenomén upútal pozornost’ vo väčšej alebo menšej 
miere všetkých bádatel'ov a zberatel’ov, ktorí uskutočnili terénne výskumy v tejto lokalite: domácich, ale aj zahraničných, odborníkov ako aj záujemcov bez profesionálnej prípravy. ${ }^{1}$ Napriek tejto skutočnosti sa ozdobnému spevu, ktorý je zastúpený v pazovských slovenských tradičných piesňach, doposial' nevenovala väčšia pozornost', prinajmenšom nie v takom rozsahu, aký si zaslúži. V štúdii sa preto sústredíme na ozdobný spev Slovákov v Starej Pazove z niekol'kých aspektov. Prvý aspekt bude sledovat doterajší stav poznania a históriu dokumentácie ozdobného spevu v tejto lokalite. Ďalej sa budeme zaoberat’ otázkou výskytu ozdôb v rámci jednotlivých hudobnoštýlových vrstiev v tradičnom speve Starej Pazovy. Tretí aspekt bude zameraný na transkripciu a deskripciu ozdôb v pazovských piesňach. Posledný aspekt bude spojený s interpretačnou stránkou a aplikáciou ozdôb v jednotlivých piesňach.

\section{Súčasný stav poznatkov o ozdobnom speve v Starej Pazove}

V súčasnosti nevieme s istotou uviest’ autora prvých zápisov pazovských piesní. S najvyššou pravdepodobnostou boli najskôr zaznamenávané len texty piesní, ked'že nie všetci zberatelia mali odborné hudobné vzdelanie. Otázkami zberatel'skej činnosti medzi Slovákmi v Starej Pazove sme sa zaoberali v príspevku Prínos Martina Kmet’a k výskumu slovenskej ludovej piesne v Starej Pazove ${ }^{2}$ a v štúdii Piesňová tradícia Slovákov v Starej Pazove. ${ }^{3} \mathrm{Na}$ tomto mieste sa preto uvedenej problematike podrobnejšie venovat’ nebudeme. Avšak pokúsime sa priniest’ chronologický prehlad o existujúcich zápisoch piesní, ktoré obsahujú ako textovú, tak i melodickú zložku.

Prvé kompletné zápisy piesní zo Starej Pazovy, o ktorých v súčasnosti vieme, pochádzajú z prvej polovice 20. storočia. Pravdepodobne vznikli v medzivojnovom období. ${ }^{4}$

\footnotetext{
PLICKA, Karol: Slovenský spevník I. Bratislava : Slovenské vydavatel'stvo krásnej literatúry, 1961, s. 42. BURLASOVÁ, Soňa: Problematika slovenských enkláv v juhovýchodnej Európe z hladiska etnomuzikologického. In: Slovenský národopis, roč. 14, 1966, č. 3, s. 467 - 471. LENG, Ladislav: Hudobné pozoruhodnosti staropazovskej piesne. In: Stará Pazova 1770 - 1970. Zborník štúdií a článkov. Ed. Ján Turčan. Nový Sad : Obzor, 1972, s. 340-351. BURLASOVÁ, Soňa: Symbióza dvoch kolonizačných vetví v piesňovej kultúre jednej obce. In: Slovenský národopis, roč. 23, 1975, č. 2, s. 245. KMEŤ, Martin: Tematicko-obsahové, hudobno-štrukturálne a prednesové zvláštnosti staropazovských piesní. In: FILIP, Michal - MIŠKOVIC, Juraj - KMEŤ, Martin: Slovenské ludové piesne zo Starej Pazovy. Báčsky Petrovec : Kultúra, 1996, s. 20-36. URBANCOVÁ, Hana: Výskum piesňovej tradície Slovákov vo Vojvodine - dokumentácia a reflexia. In: SKLABINSKÁ, Milina (ed.): Slovenská hudba vo Vojvodine. Zborník prác X. konferencie muzikológov a hudobných odborníkov, Nový Sad, 21. novembra 2014. Nový Sad : Ústav pre kultúru vojvodinských Slovákov, 2015, s. 9-32. URBANCOVÁ, Hana: Vybrané kapitoly z dejín slovenskej etnomuzikológie. Bratislava : Ústav hudobnej vedy SAV, 2016, s. 63-85.

2 LOMENOVÁ, Kristína: Prínos Martina Kmeta k výskumu slovenskej ludovej piesne v Starej Pazove. In: SKLABINSKÁ, Milina (ed.): Slovenská hudba vo Vojvodine 2016. Zborník prác 12. konferencie muzikológov a hudobných odborníkov. Nový Sad : Ústav pre kultúru vojvodinských Slovákov, 2017, s. 29-46.

3 LOMEN, Kristina: Piesňová tradícia Slovákov v Starej Pazove. In: Ethnomusicologicum V. Ed. Hana Urbancová. Bratislava : Ústav hudobnej vedy Slovenskej akadémie vied, 2017, s. 183-277.

4 URBANCOVÁ, Výskum piesňovej tradície Slovákov vo Vojvodine - dokumentácia a reflexia, Ref. 1, s. 16.
} 
Pochádzajú od niekol'kých autorov. Ako prvého môžeme uviesț Benjamína Kamenára (1875 - 1953). Jeho zbierka obsahuje až 85 záznamov. ${ }^{5}$ Bližšie datovaná nie je, avšak z historickej literatúry sa môžeme dozvediet', že do Starej Pazovy prišiel ako učitel' v roku 1900, pričom od roku 1914 dlhodobo pôsobil ako správca školy. ${ }^{6}$ Domnievame sa preto, že môže ísț o prvú zbierku slovenských ludových piesní (obsahujúcu melodickú a textovú zložku) zo Starej Pazovy. Aj ked’ nemáme bližšie informácie o hudobnom vzdelaní B. Kamenára, zo zápisov vyplýva, že ich autor mohol mat základné hudobné vzdelanie. Piesne sú transkribované pomerne jednoduchým spôsobom: v tóninách so žiadnym, prípadne jedným predznamenaním, väčšina piesní je zapísaná v pravidelnom, prevažne 2/4 metre, pričom zapisovatel' využíva najmä osminové a štvrtové rytmické hodnoty. Z 85 zápisov ani jeden nedokumentuje ozdobný spev typický pre slovenské piesne $\mathrm{z}$ tejto lokality.

Uvedené charakteristiky Kamenárových zápisov v súčasnosti nepredstavujú typické znaky pazovských piesní, ktoré v priebehu posledných približne sto rokov mohli nadobudnút inú podobu. Predpokladáme však, že v minulosti mohla byt’ tendencia využívania ozdôb v speve skôr bohatšia. Chýbajú aj pasportizačné údaje o informátoroch či dátum zápisu piesní. O niečo dôslednejšie je dokumentovaná textová stránka piesní. Z tematického a žánrového hladiska tu nájdeme predovšetkým lúbostné piesne, v menšom zastúpení balady, vojenské piesne, svadobné piesne, detské hry či sociálne piesne. Z repertoáru, ktorý zaznamenal B. Kamenár, sme v rámci nášho vlastného terénneho výskumu zdokumentovali len 18 piesní. Pri porovnávaní Kamenárových a našich zápisov sme zistili, že sa väčšina z nich z hladiska zápisu melódie (čiastočne aj textu) vo väčšej miere vzájomne líši. Ide jednak o textové varianty s celkom odlišnými nápevmi, jednak o hudobno-textové varianty. Pri porovnávaní je však, samozrejme, potrebné zohladnit' aj odlišný prístup k hudobnému zápisu. Možno sa hypoteticky domnievat', že v prípade spoločných melodicko-rytmických variantov Kamenárove hudobné zápisy predstavujú zjednodušený záznam základnej melodickej línie piesne s pevnou rytmicko-metrickou štruktúrou. Z početnejšej Kamenárovej zbierky uvádzame príklady troch piesní: lúbostnú pieseň Tam s tej strane za Dunajom (Príloha, Príklad 1a), vojenskú pieseň Širom poli hruška stojí (Príklad 2a) a baladu Pri Brode na vode (Príklad 3a). Na porovnanie uvádzame príklady rovnakých piesňových typov z roku 2014 v našom vlastnom zápise (Príklad 1b, Príklad 2b, Príklad 3b).

Piesňová zbierka B. Kamenára predstavuje cenný historický dokument. Zápisy týchto piesní neboli doposial' spracované a ani bližšie zhodnotené. Sú súčastou zbierky rukopisných záznamov slovenských ludových piesní z bývalej Juhoslávie, ktoré sa nachádzajú v Rukopisnej zbierke ludových piesní Etnomuzikologického oddelenia ÜHV SAV. Táto piesňová zbierka by si v budúcnosti vyžadovala samostatný výskum.

5 ELSCHEKOVÁ, Alica: Výskum ludových piesní na Slovensku a u Slovákov v zahraničí. In: SKLABINSKÁ, Milina (ed.): Slovenská hudba vo Vojvodine. Zborník prác 1. konferencie muzikológov a hudobných odborníkov, Nový Sad, 16. apríla 2005. Nový Sad : Národnostná rada slovenskej národnostnej menšiny v Srbsku a Čiernej Hore, 2006, s. 17.

6 V 30. rokoch 20. storočia bol stále správcom školy, ale aj okresným škôldozorcom. In: LILGE, Karol: Stará Pazova, monografia. Myjava : tlačou a nákladom D. Pažického, 1932, reprint v roku 2010. Stará Pazova : Miestny odbor Matice slovenskej; Bomil Print, 2010, s. 77-87.

7 ELSCHEKOVÁ, Ref. 5. 
Rukopisné záznamy dvoch piesní pochádzajú od hudobného pedagóga, skladatela, dirigenta a zberatela slovenských ludových piesní Antona Cígera (1911 - 1976). Zápisy týchto piesní sú datované do obdobia medzi rokmi 1930 a 1955 . Domnievame sa, že zápisy piesní mohli vzniknút počas pobytu zberatela vo vtedajšej Juhoslávii (v Záhrebe), kde študoval kompozíciu a dirigovanie (koncom 20. a začiatkom 30. rokov 20. storočia). Zrejme ide skôr o príležitostné záznamy, než o cielený výskum. ${ }^{8}$ Aj pri týchto záznamoch nachádzame len selektívne sprievodné dáta. Nie je uvedený rok zápisu ani žiadne informácie o spevákoch či spevných príležitostiach. Cígerove zápisy pazovských piesní však svedčia o odbornom hudobnom vzdelaní autora. $\mathrm{Na}$ rozdiel od Kamenárovej zbierky záznamy A. Cígera dokumentujú ozdobný spev tejto lokality. V jeho zápisoch nachádzame prírazy, odrazy, drobné ozdoby, melizmy či glissandá. Piesne sú transkribované v pravidelnom 4/4 a 3/4 metre. Pri oboch piesňach zapísal len dve strofy. Pravdepodobne nejde o kompletné texty týchto piesní. Autor zaznamenal dve lúbostné piesne: Štyri kone vrané (Príklad 4) a Ked' pôjd’em z Pazova (Príklad 5a). Na porovnanie uvádzame náš zápis piesne Ked'pójdem z Pazova (Príklad 5b), ktorú sme dokumentovali v rámci vlastného terénneho výskumu. Pri komparácii týchto zápisov badáme minimálne zmeny - ako melodické, tak i metricko-rytmické. Cígerove zápisy piesní sú súčastou Rukopisnej zbierky ludových piesní Etnomuzikologického oddelenia ÚHV SAV.

Určitý počet piesní zaznamenal aj učitel’ Michal Litavský zo Starej Pazovy (1908 - 1983). Kompletný rozsah Litavského zbierky v súčasnosti nepoznáme, avšak jej čast’ bola publikovaná v roku 1932 v monografii Stará Pazova. ${ }^{9} \mathrm{~V}$ tejto monografii je zverejnených 33 piesní, pričom $6 \mathrm{z}$ nich obsahuje aj notový zápis. Ide o piesne Na Dunaji šati prali (č. 2), Zaleteu sokolík (̌̌. 4), Žjav, žjav, komu žjav (č. 14), Tajšlo djovča gu spovedi (č. 17), Chodím, blúdim, v Ameriki (č. 18), Na cimbalách hrajú (č. 29). V uvedených piesňach autor detailne zapísal aj ozdoby. Etnomuzikológ Martin Kmet tieto zápisy zhodnotil ako vel'mi adekvátne. ${ }^{10} \mathrm{~K}$ podobnému názoru sa prikláňal aj slovenský etnomuzikológ Ladislav Leng, ktorý vo svojej štúdii Hudobné pozoruhodnosti staropazovskej piesne využil ako príklad ozdobného pazovského spevu aj dva zápisy piesní M. Litavského. ${ }^{11}$

V súčasnosti nemáme žiadne poznatky o hudobnom vzdelaní M. Litavského, ani bližšie informácie k postupom, ktoré využíval pri zbieraní a zapisovaní piesní - nevieme, či zapisoval priamo na mieste, či využíval zvukovú dokumentáciu a piesne transkriboval zo zvukového záznamu. K dispozícii nemáme ani informácie o jeho informátoroch. Pri publikovaných piesňach absentujú akékolvek sprievodné dáta. Avšak spolu s M. Kmetom a L. Lengom môžeme konštatovat', že Litavský si dal záležat na čo najpresnejšom hudobnom zápise piesní. Môžeme tak usúdit’ na základe piesní, ktoré sme dokumentovali $\mathrm{v}$ tejto lokalite $\mathrm{v}$ rámci nášho terénneho výskumu. $\mathrm{V}$ notových príkladoch zaznamenal prírazy, odrazy, dvojité prírazy, dvojité odrazy, skupinky nôt či

8 ELSCHEKOVÁ, Ref. 5. URBANCOVÁ, Výskum piesňovej tradície Slovákov vo Vojvodine, Ref. 1, s. 13.

9 LILGE, Ref. 6, s. 222-234.

10 KMET, Ref. 1, s. 20.

11 LENG, Ladislav: Hudobné pozoruhodnosti staropazovskej piesne. In: TURČAN, Ján (ed.): Stará Pazova 1770 - 1970. Zborník štúdií a článkov. Nový Sad : Obzor, 1972, s. 341, s. 351. 
melizmy. Na ukážku uvádzame tri Litavského zápisy: vojenskú pieseň Zaleteu sokolík (Príklad 6a), lúbostnú pieseň Žjav, žjav, žjav mi je (Príklad 7a) a vystahovaleckú pieseň Chodim blúdim v Ameriki (Príklad 8). Podrobné zápisy svedčia jednak o presnosti, $\mathrm{s}$ akou autor pristupoval k svojim zápisom, jednak o ustálenom piesňovom repertoári Pazovčanov a v neposlednom rade aj o zaužívanej interpretácii týchto piesní, ktorá neobsahuje výrazné zmeny ani po takmer sto rokoch. Na porovnanie uvádzame pod prvými dvomi príkladmi aj naše vlastné zápisy týchto piesní (Príklad 6b, Príklad 7b). Uvedenú vystahovaleckú pieseň (Príklad 8) sme pri našom výskume nezaznamenali.

V roku 1937 v Starej Pazove uskutočnil terénny výskum folklorista a etnograf Karol Plicka (1894 - 1987). ${ }^{12}$ V Slovenskom spevníku I, ktorý vyšiel v roku 1961, je zverejnených 5 zápisov piesní z tejto lokality. V štyroch z nich Plicka zaznamenal ozdobný spev. Ide o tahavé nápevy s pomalým prednesom. Ozdobný spev sa nachádza v piesňach: Ej, čo som urobila (č. 90), ${ }^{13}$ Ked’ pojdem z Pazova (č. 219), ${ }^{14} \mathrm{Na}$ cimbalách hrajú (č. 264), ${ }^{15}$ Nechceu som Pazove (č. 289). ${ }^{16}$ Zo Starej Pazovy pochádza aj pieseň Sticha, mily, pomaly (č. 375), v ktorej autor zaznamenal len niekol'ko ozdôb a glissánd. V posledných rokoch prebieha spracovanie pozostalosti Karola Plicku, ktorému sa venuje muzikologička Miriam Timková. ${ }^{17}$ Vo svojej štúdii s názvom Pozostalost' Karola Plicku a problémy jej spracovania prináša kompletný súpis Plickových zápisov piesní zo všetkých lokalít na Dolnej zemi, v ktorých tento zberatel' realizoval terénny výskum. Okrem 5 zverejnených zápisov, ktoré sme uviedli vyššie, d’alšie 2 sa vyskytujú v Plickovej pozostalosti uloženej v Slovenskom národnom múzeu v Martine. Ide o dve zbojnícke piesne: Pod orieškom pod zeleným a Ide furman dolinou. ${ }^{18} \mathrm{~V}$ Literárnom archíve Slovenského národného múzea v Martine sa nachádza zápis jednej piesne Sedí vrabec na kostole. ${ }^{19}$ Celkový počet Plickových zápisov zo Starej Pazovy tak predstavuje 8 hudobno-textových záznamov.

Aj ked' Plickove zápisy z tejto lokality nie sú početné, sú významné z niekol'kých aspektov. Pravdepodobne patria k prvým, ktoré boli zaznamenané profesionálnym zberatelom s vyhraneným názorom na prístup k piesňovej dokumentácii. Ďalším pozoruhodným aspektom je mimoriadna precíznost’ pri zápise piesňového materiálu. ${ }^{20}$

\footnotetext{
PLICKA, Ref. 1, s. 10.

PLICKA, Ref. 1, s. 123.

PLICKA, Ref. 1, s. 197.

PLICKA, Ref. 1, s. 222.

PLICKA, Ref. 1, s. 237.

17 TIMKOVÁ, Miriam: Pozostalost' Karola Plicku a problémy jej spracovania. In: Musicologica Slovaca, roč. 6 [32], 2015, č. 1, s. 121-171. TIMKOVÁ, Miriam: Piesňový repertoár Slovákov na Dolnej zemi v zápisoch Karola Plicku. In: Ethnomusicologicum V. Bratislava: Ústav hudobnej vedy SAV, 2017, s. 150. TIMKOVÁ, Miriam: Ťahavé piesne v zápise Karola Plicku. Na príklade piesňových žánrov zo stredného Považia. In: Musicologica Slovaca, roč. 9 [35], 2018, č. 1, s. 103-124. TIMKOVÁ, Miriam: Slovenské ludové piesne z Trenčianskej stolice v zápisoch Karola Plicku. In: Hudobný archív 17. Ed. Martina Božeková. Martin : Slovenská národná knižnica, 2018, s. 151-176. TIMKOVÁ, Miriam: Piesňové druhy a žánre v zberatel'skej koncepcii Karola Plicku. In: Musicologica Slovaca, roč. 11 [37], 2020, č. 2, s. 274-302.

18 TIMKOVÁ, Pozostalost' Karola Plicku a problémy jej spracovania, Ref. 17, s. 142-148.

19 Tamtiež.

20 Pozri tiež: MICHALOVIČ, Peter: Staršie zápisy ozdobného spevu na Záhorí a súčasný prístup $\mathrm{k}$ nim. In: Ethnomusicologicum 1/1. Ed. Stanislav Dúžek. Bratislava : Ústav hudobnej vedy Slovenskej akadémie vied; ASCO Art \& Science, 1993, s. 89.
} 
Napriek rôznym názorom na adekvátnost' Plickovej zberatel'sko-dokumentačnej metódy hodnotíme jeho zápisy ozdobného spevu zo Starej Pazovy ako relevantné. Podrobne zapisoval nielen melodickú, ale aj textovú stránku piesní. Podrobne sú zaznamenané aj ozdoby v jednotlivých piesňach (nielen pazovských), ktoré Plicka podrobne rozpisoval. Ozdobný spev alebo zdobený spev, ako ho označil, považoval Plicka „za vrchol ludového speváckeho podania slovenského".21 Takýto spev zaznamenal najmä na Záhorí a na východnom Slovensku (Zemplín). Podla jeho názoru je takéto zdobenie prejavom archaického štýlu, ale aj výsledkom vplyvu rôznych regionálnych hudobných dialektov. ${ }^{22} \mathrm{~K}$ samotnému ozdobnému spevu v Starej Pazove sa však na tomto mieste nevyjadruje.

Ako príklad zápisu bohatého zdobenia môžeme uviest' tri pazovské piesne z jeho zbierky: Ej, čo som urobila (Príklad 9), Na cimbalách hrajú (Príklad 10) a Ked’pojdem z Pazova (Príklad 11). Transkripciu poslednej uvedenej piesne sme porovnali so zápisom M. Litavského (Príklad 5a) a naším vlastným zápisom (Príklad 5b). Podobný melodicko-rytmický zápis svedčí nielen o ustálenosti pazovského piesňového repertoáru, ale aj o dôveryhodnosti Plickovho zápisu, ktorú v súčasnosti môžeme overit len pomocou takejto komparácie. Spol’ahlivý sa nám javí aj d’alší príklad, kde zberatel' zaznamenal ozdoby. Ide o zbojnícku pieseň Pod orieškom pod zeleňím (Príklad 12), ktorá sa v súčasnosti nachádza len v rukopisnej pozostalosti autora. Uvedený zápis sme porovnali s našou transkripciou. Melodicko-rytmická podobnost’ sa potvrdila aj pri tejto komparácii. ${ }^{23}$

Najpočetnejšiu zbierku piesní v Starej Pazove zaznamenal slovenský muzikológ Jozef Kresánek (1913 - 1986). Terénny výskum v uvedenej lokalite realizoval v roku 1947. Piesňový repertoár, ktorý tu zapísal, tvorí až 304 piesní. ${ }^{24}$ Takáto rozsiahla zbierka svedčí o jedinečnosti pazovských piesní, ktoré v značnej miere upútali Kresánkovu pozornost'. Piesne transkriboval priamo na mieste z podania jednotlivých pazovských spevákov. ${ }^{25}$ Avšak väčšina Kresánkových zápisov piesní z prostredia dolnozemských Slovákov (nielen zo Starej Pazovy) doposial' nebola zverejnená a miesto ich uloženia je v súčasnosti neznáme. Výnimku tvorí len niekolkko piesní. Jednou z nich je pieseň Voly, voly, sivie voly zo Selenče, ktorú publikoval vo svojej práci Slovenská ludová pieseň zo stanoviska hudobného. ${ }^{26}$ Niektoré Kresánkove zápisy pazovských piesní boli zverejnené v štúdii L. Lenga Hudobné pozoruhodnosti staropazovskej piesne. Ide o piesne Frajer moj vereňí (Príklad 13) a Pod javorňičkom bistrá voda (Príklad 14). Určitý počet Kresánkových zápisov sa nachádza aj v zbierke piesní Slovenské ludové piesne zo Starej Pazovy. ${ }^{27}$ Autori tejto publikácie však neuviedli konkrétne, o ktoré

$21 \quad$ PLICKA, Ref. 1, s. 42.

22 URBANCOVÁ, Vybrané kapitoly z dejín slovenskej etnomuzikológie, Ref. 1, s. 68-69.

23 Náš vlastný zápis tejto piesne je dostupný In: LOMEN, Ref. 3, s. 272 (Príklad 48).

24 LENG, Ref. 11, s. 341. URBANCOVÁ, Výskum piesňovej tradície Slovákov vo Vojvodine, Ref. 1, s. $14-15$.

25 LENG, Ref. 11, s. 341.

26 KRESÁNEK, Jozef: Slovenská ludová pieseň zo stanoviska hudobného. Bratislava : Národné hudobné centrum, ${ }^{2} 1997$, s. 133.

27 S určitostou vieme, že Kresánek zapísal pieseň č. 310b Spod javorňička bistrá voda, ktorá bola publikovaná v štúdii L. Lenga. In: LENG, Ref. 11, s. 347. Autori zbierky piesní zo Starej Pazovy dalšie Kresánkove zápisy presne neuvádzajú, zároveň mu však pripisujú určitý počet dalších 
piesne ide. ${ }^{28} \mathrm{Z}$ týchto nepočetných zverejnených transkripcií je evidentné, že aj Kresánek si dal mimoriadne záležat na čo najpresnejšom zápise náročného pazovského ozdobného spevu. Jeho ostatné zápisy pazovských piesní nie sú v súčasnosti odbornej verejnosti dostupné.

Ďalšie zápisy slovenských ludových piesní zo Starej Pazovy pochádzajú z 50. rokov 20. storočia. Nachádzajú sa v publikovanej zbierke Ludové piesne Slovákov vo Vojvodine (2004). ${ }^{29}$ Ich autorom je dolnozemský zberatel' Juraj Ferík starší (1908 - 1993). Zbierka vyšla na podnet zberatelovho syna Juraja Feríka mladšieho (1935 - 1918). Zberatel'ská činnost' J. Feríka st. je významná z niekolkých aspektov. Jednak je prvým tamojším autorom, ktorý sa venoval dokumentovaniu tradičných piesní v prostredí vojvodinských Slovákov systematicky, jednak je jedným z prvých domácich autorov, ktorí dôsledne zapisovali nielen texty, ale aj nápevy piesní. Pri publikovaných piesňach sú uvedené aj niektoré pasportizačné údaje, akými sú: meno speváka, rok zápisu piesne, prípadne vek speváka, ojedinele aj jeho povolanie. Zbierkový korpus je pozoruhodný aj z teritoriálneho hladiska - piesňový materiál, ktorý zozbieral, pochádza takmer zo všetkých slovenských lokalít vo Vojvodine. ${ }^{30}$

Čast' výsledkov jeho dlhoročnej zberatel'sko-dokumentačnej práce je zverejnená v uvedenej zbierke piesní. Spomedzi 784 slovenských ludových piesní, ktoré sa v zbierke nachádzajú, až 65 piesní pochádza zo Starej Pazovy. Dokumentáciu piesňového materiálu v tomto meste J. Ferík st. realizoval v rokoch 1950 - 1958. Najvyšší počet záznamov pochádza z roku 1956 (45 piesní). Je pozoruhodné, že sa snažil zaznamenávat aj ozdoby charakteristické pre slovenské piesne v tejto lokalite - zo 65 záznamov až 49 piesní dokumentuje ozdobný spev. Aj ked' nejde o také detailné zápisy, ako pred ním realizoval Karol Plicka, Feríkove zápisy zachytávajú ozdobný spev typický pre piesňový repertoár Slovákov v Starej Pazove. Ako príklad uvádzame zápisy troch piesní, v ktorých autor zaznamenal početnejšie ozdoby: vojenskú pieseň Pri mitrouskej bráňi (Príklad 15), ${ }^{31}$ lúbostnú pieseň Lastovienka lieta (Príklad 16) ${ }^{32}$ a vojenskú pieseň Ke zme Varadiňe (Príklad 17). ${ }^{33}$

Nepočetné, ale zato pozoruhodné a vzácne zápisy pazovských piesní pochádzajú od etnomuzikológa Ladislava Lenga (1930 - 1973), ktorý bol členom výskumného tímu vo Vojvodine v 60. rokoch 20 . storočia. ${ }^{34}$ Pri terénnych výskumoch nahrával piesne na magnetofónové pásy a záznamy podla účelu dodatočne transkriboval. ${ }^{35}$ Celkovo v Starej Pazove nahral 250 melodických piesňových jednotiek na 14 magnetofónových

záznamov. In: FILIP, Michal - MIŠKOVIC, Juraj - KMEŤ, Martin: Slovenské ludové piesne zo Starej Pazovy. Báčsky Petrovec: Kultúra, 1996, s. 42, 334, 268, 414.

28 FILIP - MIŠKOVIC - KMEŤ, Ref. 27, s. 334, 414.

29 FERÍK, Juraj: L’udové piesne Slovákov vo Vojvodine. Báčsky Petrovec : Kultúra, 2004.

30 FERÍK, Ref. 29, s. 459.

31 FERÍK, Ref. 29, s. 241.

32 FERÍK, Ref. 29, s. 252.

33 FERÍK, Ref. 29, s. 266.

34 DÚŽEK, Stanislav: Etnomuzikologický výskum juhoslovanských Slovákov. In: Slovenský národopis, roč. 23, 1975, č. 2, s. 259-263. URBANCOVÁ, Výskum piesňovej tradície Slovákov vo Vojvodine, Ref. 1, 2015, s. 18.

35 LENG, Ref. 11, s. 351. 
pásoch. ${ }^{36}$ Svoje zápisy uverejnil v dvoch publikáciách: v štúdii Hudobné pozoruhodnosti staropazovskej piesne $e^{37}$ a v piesňovej zbierke Slovenské ludové piesne zo Starej Pazo$v y .{ }^{38} \mathrm{~V}$ oboch sa nachádzajú Lengove zápisy štyroch piesní: Ninto po pounoci, ${ }^{39}$ Aj, pola nás, pol’a nás, ${ }^{40}$ Ked'zme išli do Mantave, ${ }^{41}$ Ket' som stal na varte. ${ }^{42}$ Podobne ako Plicka aj Leng zaznamenal pazovské slovenské piesne detailne, vrátane zápisu ozdobného spevu. Záznamy, ktoré uvádza, sa vyznačujú dôsledným zachytením výšky tónov a rytmickej stránky, ale aj precíznym vypísaním ozdôb. Okrem toho detailne rozpisoval aj hlasové vibrato, čo je jednou z typických charakteristík jeho transkripcie. Ako príklad uvádzame piesne Ninto po pounoci (Príklad 18), Aj, pol’a nás, pola nás (Príklad 19), Ked' zme išli do Mantave (Príklad 20). Značná čast' Lengovej zbierky piesní zo Starej Pazovy sa aj v súčasnosti nachádza na magnetofónových pásoch v archíve Etnomuzikologického oddelenia ÚHV SAV. Tie by bolo potrebné excerpovat', transkribovat', podrobit' etnomuzikologickej analýze a následne vyhodnotit.

Okrem detailných zápisov je výskumná práca L. Lenga významná aj z hladiska etnomuzikologického pohladu na pazovské piesne. Nachádzame ju v už spomenutej štúdii Hudobné pozoruhodnosti staropazovskej piesne, ktorá predstavuje prvú komplexnejšiu teoretickú reflexiu v súvislosti s pazovským spevom vôbec. Terénni pracovníci sa sústredili najmä na dokumentáciu piesňového materiálu, ale v ovela menšej miere na jeho teoretické vyhodnotenie. Informácie zahrnuté v štúdii sú cenné aj z historického hladiska. Vdaka tejto štúdii si môžeme pomerne jasne vytvorit’ obraz o pazovských piesňach a ich speve v 60. rokoch a na začiatku 70. rokov minulého storočia. Navyše, ešte aj v súčasnosti ide o jednu z mála štúdií, ktoré sa venujú problematike pazovského spevu. L. Leng v nej čiastočne zhrnul celý vtedajší stav dokumentácie pazovských piesní, d’alej hovoril o tematickej stránke piesní a ich sociálnej funkcii. Následne pristúpil $\mathrm{k}$ ich analýze $\mathrm{z}$ hladiska tonality, melódie, ambitu, tempa a metra. V závere štúdie sa zmienil o interpretačno-štýlovej stránke piesní, v rámci ktorej sa zameral aj na ozdobnost’ spevu. Tú považoval za najcharakteristickejšiu črtu pazovskej slovenskej ludovej piesne. ${ }^{43} \mathrm{~K}$ jeho klasifikácii ozdôb sa ešte vrátime.

Pozoruhodné zápisy pazovských piesní pochádzajú od Martina Kmeta (1926 - 2011). Ako etnomuzikológ pochádzajúci z prostredia vojvodinských Slovákov sa venoval nielen dokumentácii tradičného spevu, ale aj jeho teoretickému zhodnoteniu. Spomedzi všetkých lokalít si práve pazovské piesne našli osobitné miesto v jeho výskumnom zábere. Zberatel'skej činnosti, výskumu a analýze týchto piesní sa venoval prakticky po celý život. Okrem L. Lenga je jediným autorom, ktorý priniesol teoretickú reflexiu v súvislosti s tradičným spevom zo Starej Pazovy. Z jeho štúdií môžeme spomenút: Vplyv ludových hudobných nástrojov na vývin pazovského spievania, ${ }^{44}$

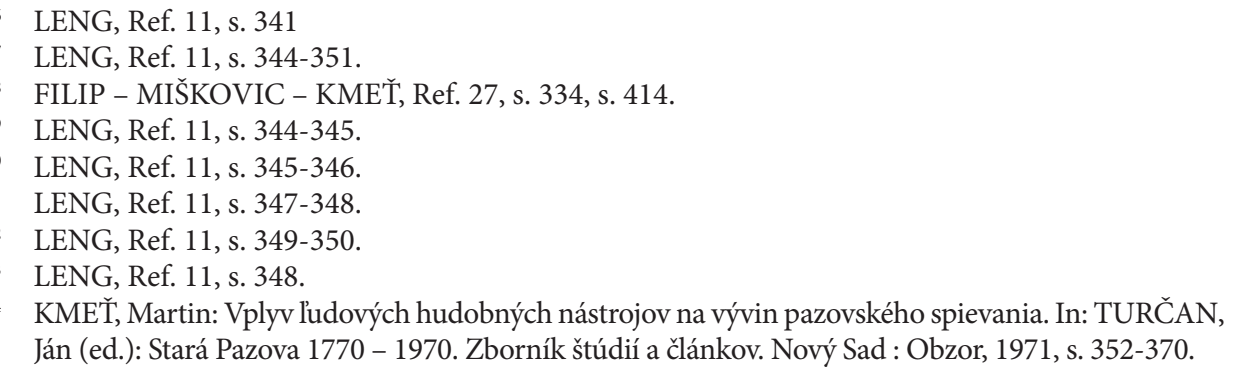


Slovačke narodne pesme iz Stare Pazove, ${ }^{45}$ Mogućnosti etnomuzikološkog objašnjenja pojave pentatonike u Staroj Pazovi i Medumurju, ${ }^{46}$ Pentatonika u Medimurju i Staroj Pazovi - sličnosti i razlike, ${ }^{47}$ Tematicko-obsahové, hudobno-štrukturálne a prednesové zvláštnosti staropazovských piesni. ${ }^{48}$

Problematikou ozdobného spevu sa M. Kmet’ zaoberal predovšetkým v prvej uvedenej štúdii. Významnou súčastou tejto štúdie sú aj jeho zápisy pazovských ludových piesní. Ich celkový počet predstavuje 15 zápisov. Podobne ako K. Plicka, L. Leng či J. Kresánek aj Kmet’ sa snažil čo najdôslednejšie zapísat’ komplikovanú interpretáciu tradičných pazovských piesní. Ako príklad uvádzame niekol'ko ukážok: Nad hraňicami drevo rúbajú (Príklad 21), Tej Pazove na placi (Príklad 22), Ke zme Varadine (Príklad 23). V súčasnosti nie je známy rozsah Kmetovej zbierky piesní zo Starej Pazovy. Jeho zápisy sú súčastou rodinného archívu. Spracovaniu jeho hudobnej pozostalosti sa v súčasnosti venuje hudobná teoretička Milina Sklabinská. ${ }^{49}$

Na tomto mieste nemožno nespomenút ani publikovanú piesňovú zbierku Slovenské ludové piesne zo Starej Pazovy, ktorá bola vydaná v roku $1996 .{ }^{50}$ Predstavuje prvú piesňovú zbierku väčšieho rozsahu z prostredia vojvodinských Slovákov. Na jej vzniku sa podielali viacerí autori, predovšetkým Michal Filip (1915 - 1989), Juraj Miškovic (1933 - 2001) a Martin Kmet. Zbierka obsahuje 535 piesní, pričom je rozdelená na tri časti. Prvá čast’ obsahuje 398 piesní. Nachádzajú sa v nej predovšetkým piesne, ktorých texty zozbieral M. Filip v rokoch 1946 - 1947 a nápevy zapísal J. Miškovic. ${ }^{51}$ Podla informácií, ktoré uvádza M. Kmet', sa tu nachádza aj 29 záznamov, ${ }^{52}$ ktoré zapísali další autori. Ide o zápisy, ktoré boli prevzaté z iných piesňových zbierok. ${ }^{53}$ Do zbierky Slovenské ludové piesne zo Starej Pazovy tak bolo zaradených už spomenutých 6 zápisov Michala Litavského, prevzatých z Monografie Stará Pazova z roku 1932. ${ }^{54}$ Prevzatých bolo aj 6 zápisov piesní K. Plicku, ktoré zverejnil v Slovenskom spevníku I. Väčšinu

${ }_{45}$ KMEĆ, Martin: Slovačke narodne pesme iz Stare Pazove (1989). In: Folklor u Vojvodini. Zv. 3. Novi Sad, 1989, s. 405-409.

46 KMEĆ, Martin: Mogućnosti etnomuzikološkog objašnjenja pojave pentatonike u Staroj Pazovi i Međumurju. In: Folklor u Vojvodini 5, 1991, s. 79-90.

47 KMEŤ, Martin: Pentatonika u Međimurju i Staroj Pazovi - sličnosti i razlike. In: Narodna umjetnost. Rasprave i prilozi uz stogodišnjicu rodjenja Vinka Žganca (Čakovec, 25. - 27. 10. 1990). Posebno izdanje 3, Zagreb, 1991, s. 367-376.

48 KMEŤ, Ref. 1.

49 SKLABINSKÁ, Milina: Esteticko-hudobné práce Martina Kmeta. V edícii: Doktorské dizertácie, zväzok 5. Báčsky Petrovec : Slovenské vydavatel'ské centrum; Nový Sad : Ústav pre kultúru vojvodinských Slovákov, 2019. SKLABINSKÁ, Milina: Martin Kmet' (1926 - 2011) - etnomuzikológ vojvodinských Slovákov. In: Musicologica Slovaca, roč. 10 (36), 2019, č. 1, s. 7-45.

$50 \quad$ FILIP - MIŠKOVIC - KMEŤ, Ref. 27.

$51 \quad$ FILIP - MIŠKOVIC - KMET̆, Ref. 27, s. 44.

52 Kmet hovorí o 25 záznamoch, pričom tento počet nezahŕňa jednotlivé piesňové varianty. Spolu s nimi ide o 29 zápisov piesní pochádzajúcich od dalších autorov. KMEŤ, Martin: Pripomienky k očíslovaniu piesní. In: FILIP - MIŠKOVIC - KMEŤ, Ref. 27, s. 42.

53 KMEŤ, Ref. 52.

54 V zbierke piesní zo Starej Pazovy sa nachádzajú pod č́slami: 110b (pieseň Chodím, blúdim $v$ Ameriki), 198-Ib (pieseň Na cimbalách hrajú), 200 (pieseň Na Dunaji šati prali), 338b (pieseň Tajšlo djovča gu spovedi), 386a (pieseň Zaleteu sokolík). 
z nich sme spomenuli vyššie. ${ }^{55}$ Do spevníka autori zaradili aj niektoré zápisy piesní J. Feríka st., ktoré pochádzajú z piesňovej zbierky Ludové piesne Slovákov vo Vojvodine. ${ }^{56}$ Ďalšie 2 zápisy boli prevzaté od L. Lenga, ${ }^{57} 1$ zápis od J. Kresánka. ${ }^{58}$ Zvyšné transkripcie ( 9 piesní) realizoval M. Kmet', nie je však zrejmé, či ide o jeho jediné zápisy, ktoré sú v zbierke zverejnené. ${ }^{59}$

Druhá čast’ zbierky obsahuje 129 piesní, ktoré zozbieral J. Miškovic. Okrem Miškovica sa podiel'al na transkripcii hudobnej zložky piesní v tejto časti zbierky aj Martin Kmet', miestny interpret v hre na harmonike Michal Ďarmotský a miestny profesionálny hudobník Michal Čemerský. Autori zbierky uvádzajú tiež určitý počet notových zápisov, ktoré boli prevzaté od J. Feríka st., J. Kresánka, L. Lenga, M. Litavského a K. Plicku. Na rozdiel od prvej časti v druhej neuvádzajú, o ktoré konkrétne zápisy ide.

V poslednej časti zbierky sa nachádzajú „Prednesy za sprievodu harmoniky“, ktoré zapísal M. Kmet', J. Kresánek a L. Leng. Táto čast’ zbierky obsahuje 8 hudobných zápisov. V závere zbierky sú umiestnené analýzy piesní a ich triedenie z niekolkých aspektov (hudobno-štrukturálna analýza, tematika piesní, komplexná hudobná charakteristika), ktoré realizoval Martin Kmet'.

Voči tejto piesňovej zbierke možno mat' niekol'ko výhrad. Aj ked'sa na jej vydaní čiastočne podielal etnomuzikológ M. Kmet', pomerne vel'kú čast’ piesňového materiálu transkriboval učitel’ matematiky Juraj Miškovic, ktorý nemal odborné hudobné vzdelanie. Táto skutočnost’ sa v značnej miere odzrkadluje aj na zápise piesní. Ďalšiu výhradu možno mat’ voči samotnému melodickému zápisu. K textom piesní, ktoré zozbieral v 40. rokoch 20. storočia profesor Michal Filip, o niekolko desatročí neskôr pribudli melodické zápisy. Uskutočnil ich J. Miškovic, pravdepodobne pomocou metódy rekonštrukcie na základe pamäti. ${ }^{60}$ Už sme spomenuli vyššie, že pri jednotlivých piesňach neboli uvedení autori, ktorí danú pieseň zapísali. V konečnom dôsledku tak môžeme len tipovat', ktoré zápisy realizovali významní bádatelia ako K. Plicka, J. Kresánek, L. Leng či M. Kmet’.

55 V zbierke piesní zo Starej Pazovy sa nachádzajú pod číslami: 67b (pieseň Ej, čo som urobila), 94b (pieseň $F$ šírom poli hruška zelená, prevzatá bola z lokality Bingula. In: PLICKA, Ref. 1, s. 324), 148b (pieseň Ked’ pójdem $z$ Pazova), 170-Ia (pieseň Kuvikali kuvici, u Plicku pod názvom Sticha mily pomaly), 198-Ia (pieseň Na cimbalách hrajú), 222a (pieseň Ňekceu som $f$ Pazove vojákom).

56 Zápisy Juraja Feríka st. z roku 1956 sa v zbierke piesní zo Starej Pazovy nachádzajú pod číslami: $34 \mathrm{~b}$ (pieseň Ces prosrjet Pazova muruvaná), 146b (pieseň Ke zme Varadiñe), 176b (pieseň Letí siví sokol), 262-Ic (pieseň Pod obločkom červeňje), a P-30 (pieseň Hej, nalej nám krčmárka).

57 V zbierke piesní zo Starej Pazovy sa nachádzajú pod číslami 76a (pieseň Ej, pola nás) a 229a (pieseň Ninto po pounoci). Ide o Lengove transkripcie piesní bez rozpísaného vokálneho vibrata.

58 Pozri Ref. 27.

59 Uvedené Kmetove zápisy boli zverejnené aj v iných publikáciách. Pozri bližšie: KMEŤ, Ref. 52. V zbierke piesní zo Starej Pazovy sa nachádzajú pod číslom: 115 (pieseň Išou čipkár s Petrovca), 125 (pieseň Jaj, mamička moja, l’akávam), 134 (pieseň Kcežli, milá, vedjed', d’e je), 173 (pieseň Lastovjenka ljeta), 189 (pieseň Medzi dvoma brehi, tïchî), 258 (pieseň Počkaj ti, mamilá, nak), 343 (pieseň To polé, kebi bolo), 358 (pieseň Už mesjačik višou, mój), 375 (pieseň Višla som ja pod obločok).

60 Túto informáciu poskytli viacerí informátori z našich výskumov, nevieme ju však s istotou overit?. Skutočnost', že melodické zápisy boli dodatočne zapísané, však uvádzajú aj autori tejto zbierky. MIŠKOVIC, Juraj: K zbierke slovenské ludové piesne zo Starej Pazovy. In: FILIP - MIŠKOVIC - KMEŤ, Ref. 27, s. 9-18, 499-500. 
Vyše 300 zápisov pazovských piesní pochádza z nášho vlastného terénneho výskumu, ktorý sme v tejto lokalite uskutočnili v rokoch 2014 a 2018. O tento piesňový materiál sa budeme opierat pri dalšom skúmaní ozdôb v tradičnom speve Slovákov zo Starej Pazovy.

V tejto časti štúdie sme podrobne zhrnuli zápisy pazovských piesní, ktoré dnes máme $\mathrm{k}$ dispozícii, ako aj ich doterajšiu teoretickú reflexiu v súvislosti s ozdobným spevom. V nasledujúcej kapitole sa bližšie zameriame na zastúpenie ozdobného spevu $\mathrm{v}$ rámci jednotlivých hudobnoštýlových vrstiev piesňového repertoáru.

\section{Zastúpenie ozdobného spevu v pazovských piesňach}

Na ukážkach pochádzajúcich od viacerých bádatelov a z rôznych období sme poukázali na rozmanité transkripcie ozdobného spevu a viaceré prístupy $\mathrm{k}$ ich zápisu. Takmer všetky zápisy svedčia o zastúpení ozdobnosti v piesňovom repertoári Starej Pazovy ešte na začiatku 70. rokov minulého storočia. Po obnovení terénnych výskumov v tejto lokalite v rokoch 2014 - 2018 sme zistili, že ozdobný spôsob spevu piesní pretrváva dodnes. Vynára sa teda niekol'ko otázok: v akej miere je ozdobný spev v uvedenej lokalite zastúpený, v akých piesňach sa vyskytuje, ktorí speváci ho pri speve uplatňujú a ako často?

Aj v súčasnosti môžeme hovorit o bohatom zastúpení ozdôb v slovenských piesňach z tejto lokality. Na tomto mieste je však nevyhnutné pripomenút', že ozdobnost' je $\mathrm{v}$ značnej miere podmienená interpretačnou zručnostou spevákov. Už v minulosti platilo, že dôslednejšiu interpretáciu ozdôb uplatňovali speváci staršej vekovej kategórie. ${ }^{61}$ $\mathrm{O}$ to viac možno $\mathrm{v}$ súčasnosti súhlasit s týmto tvrdením. Tradičné piesne predstavovali bežnú súčast každodenného života predovšetkým pre spevákov a speváčky najstaršej, ale aj strednej generácie. Pre väčšinu predstavitelov mladšej generácie tieto piesne boli a sú len jednou, čoraz menej populárnou alternatívou hudobného prejavu. Táto skutočnost’ sa čiastočne odráža aj v uplatňovaní ozdôb v speve tradičných piesní. Podla niektorých autorov je ozdobný spev do určitej miery improvizačnou záležitostou. ${ }^{62}$ Je prirodzené, že jedna a tá istá pieseň v podaní dvoch spevákov nezaznie rovnako. Dokonca aj v interpretácii jedného a toho istého speváka sa nám bude javit odlišne. Napriek tomu záznamy piesní z terénnych výskumov jasne poukazujú na zručnejšiu schopnost improvizácie a zdobenia u spevákov staršej a strednej generácie. O uplatnení ozdôb v tradičnom speve zo Starej Pazovy sa vyjadril aj jeden z informátorov, Pavel Leštan (1964 - 2015). Pre zaujímavost uvádzame jeho predstavu a názor na interpretáciu ozdobného spevu v tejto lokalite:

„Ja som nepočul ešte dvoch spevákov pazovských, aby jednu pieseň zaspievali úplne rovnako, pretože pazovská piesen̆ sa nespieva, ona sa interpretuje. Takže každý si tam ozdoby dáva voláko po svojom, ale stále je to v tom jednom duchu, v tom pazovskom. Voláka tolerancia tu je, ale nemóže to byt až príliš. Postupne sa to stráca, pretože ludia si nedokážu zapamätat nosnú melódiu, hlavnú melódiu a kde v tej melódii ozdoby

${ }_{61}$ LENG, Ref. 11.

62 PAKSA, Katalin: Connection of Style and Dialect in the Ornamentation of Hungarian Folksongs. Studia Musicologica Academiae Scientiarum Hungaricae, roč. 34, 1992, č. 1-2, s. 73-80. 
majú byt. Takže ozdoby vieme, kde sú (ak vieme), a potom si ich urobíme tak, ako nám to ide z hrdla. Takže preto v pazovskej piesni je vela variantov. Čo spevák, to interpretácia. To je možno také špecifikum."

(Pavel Leštan, apríl 2014)

Vo všeobecnosti platí, že ozdobný spev sa vyskytuje najmä v piesňach pomalého rubatového charakteru (tzv. tahavých piesňach) alebo mierne rýchleho tempa. V piesňach s rýchlym tempom sa ozdoby vyskytujú v ovela menšej miere. Predovšetkým pomalé tempo umožňuje spevákovi lepšie vyspievat’ početné a komplikované ozdoby.

Tematické zameranie piesní, v ktorých sa objavuje bohatšia ozdobnost', nie je natol'ko rozmanité. Pomalé tempo, ktoré je jedným z predpokladov jej aplikovania, sa v tejto lokalite spája s piesňami, v ktorých dominuje smutná, neštastná až tragická tematika. S početnými ozdobami sa preto môžeme stretnút predovšetkým vo vojenských a regrútskych piesňach, ktoré majú jedinečné postavenie v piesňovom repertoári Starej Pazovy. ${ }^{63}$ Ako príklad uvádzame vojenskú pieseň Ke som stáv na várte (Príklad 24) a regrútsku pieseň Počkajte regrúti (Príklad 25). Ozdobnost’ je bohato zastúpená napríklad aj v lyrických lúbostných piesňach (Cesta hore, druhá dole, Príklad 26, Už zora višla, Príklad 28), v baladách (Kačička divoká, Príklad 27, Bou edom Štefam král', Príklad 47), vystahovaleckých piesňach (Ameriki roboti zastáli, Príklad 29), ale aj v svadobných piesňach pomalšieho charakteru, medzi ktorými sa vyskytujú aj niektoré obradové piesne (svadobná obradová pieseň Sadaj si Aňička, Príklad 30).

Najdôslednejší prehlad o miere uplatňovania ozdôb získame, ak sa pozrieme na ich výskyt v rámci jednotlivých hudobnoštýlových vrstiev, ktoré sú zastúpené v tradičnom speve tejto lokality. $\mathrm{V}$ rámci štúdie vychádzame $\mathrm{z}$ transkribovaného materiálu, ktorý v súčasnosti tvorí 314 záznamov.

S minimálnym zastúpením ozdôb sme sa stretli v starej piesňovej kultúre. V našom piesňovom materiáli ju v súčasnosti zastupuje 37 záznamov, pričom najpočetnejšie sú kvinttonálne nápevy (31 záznamov). V prednese magicko-rituálnych piesní sme nedokumentovali prakticky žiadne ozdoby. Môžeme sa tu výnimočne stretnút s hlasovým vibratom (ak ho spevák uplatní), s glissandom len ojedinele. Podobne je to aj pri piesňach rolníckej kultúry. ${ }^{64}$ Väčšina existujúcich klasifikačných systémov nepovažuje hlasové vibrato ani glissando za ozdoby. Odborná spevácka didaktická literatúra ich radí k vokálnej artikulácii. ${ }^{65} \mathrm{Z}$ tohto vyplýva, že v magicko-rituálnych piesňach sa žiadne ozdoby nevyskytujú. Avšak L. Leng považoval vokálne vibrato a glissandá konkrétne v pazovskom speve za charakteristické prvky tzv. melizmatických ozdôb. ${ }^{66} \mathrm{~K}$ vokálnemu vibratu sa v súvislosti s tradičnými piesňami v Starej Pazove vyjadril nasledovne:

63 LOMEN, Ref. 3, s. 187-188.

64 Je potrebné však poukázat’ na skutočnost', že v Starej Pazove sme sa nestretli s kvarttonálnymi nápevmi, ktoré by mali jasne vymedzenú kvartovú kostru. Minimálny počet záznamov, ktoré sme sem zaradili, tvorili nápevy na pomedzi kvarttonality a kvinttonality. Bližšie pozri: LOMEN, Ref. 3, s. 202-203.

65 SMUTNÁ-VLKOVÁ, Mária: Metodika spevu pre poslucháčov konzervatórií a dialkove študujúcich, 1. čast'. Praha : Supraphon, 1967. VRCHOTOVÁ-PÁTOVÁ, Jarmila: Didaktika sólového zpěvu pro studující katedry zpěvu a operní režie. Praha : Slovenské pedagogické nakladatel'stvo, 1990.

66 LENG, Ref. 11, s. 348. 
„Vokálne vibrato nepovažujeme za fyziologickú nevyhnutnosṫ. Ale v staropazovskej piesňovej kultúre je súčastou interpretačného štýlu a je rovnocenné ostatným melodickým ozdobám. Je to vibrato vel'ké s uvedomeným zrýchlovaním a spomalovaním, akoby paralela emocionálnej excitácie a útlmu. Preto je podmieňované emocionálnym typom interpreta." ${ }^{67}$

L. Leng mal pravdepodobne podobný názor aj na uplatňovanie glissánd. Aj ked'sa úplne nestotožňujeme s jeho klasifikáciou, nemožno popriet’ skutočnost', že v pazovských piesňach sa hlasové vibrato a glissando vyskytujú mimoriadne často. Z tohto hladiska majú v piesňovom repertoári tejto lokality jedinečné postavenie. Na ukážku uplatňovania hlasového vibrata a glissánd v magicko-rituálnych piesňach uvádzame uspávanku Hajíkaj, buíkaj (Príklad 31).

Nepočetné ozdoby sme zaznamenali aj pri piesňach pastiersko-valaskej kultúry. Môžeme sa tu stretnút predovšetkým s hlasovým vibratom či glissandami. Avšak na rozdiel od predchádzajúcich dvoch skupín sa tu výnimočne objavujú aj niektoré d’alšie ozdoby. Ich charakteristike sa budeme venovat' v samostatnej kapitole. Ako príklad rozmanitého zastúpenia ozdôb v tejto hudobnoštýlovej vrstve uvádzame dve ukážky: svadobnú pieseň Visoko zorňička (Príklad 32) s o niečo vyšším uplatnením ozdôb a lúbostnú pieseň s tahavým nápevom trávnicového typu Milí, mil’ (Príklad 33), v ktorej speváčka uplatňuje ozdoby relatívne často. Táto lúbostná pieseň využíva nápevový typ lúčnych piesní rozšírený na Podpol’aní. ${ }^{68}$

Najbohatšie, najpestrejšie, najrozmanitejšie a najpočetnejšie ozdoby sme zaznamenali v prechodnej štýlovej medzivrstve piesní vo všetkých jej skupinách: pri modálnych piesňach (9 záznamov), pentatonických piesňach (93 záznamov) a pri hypotonálnych piesňach (16 záznamov). Stretneme sa tu s najširším spektrom ozdôb, aké môžu pazovské piesne obsahovat'. Na ukážku ozdobného spevu zastúpeného v štýlovej medzivrstve uvádzame niekol'ko záznamov: modálnu pieseň Pri mitrovskej bráňi (Príklad 34), pentatonické piesne Lastovienka lieta (Príklad 35), Ked’ pójd’em z Pazova (Príklad 36), Kačička divoká (Príklad 27), Teraz som si počau (Príklad 37) a hypotonálne piesne Na doliňe stála (Príklad 38), Ej, furmaňia idú (Príklad 39). Všetky uvedené ukážky majú prevažne pomalé tempo, ktoré umožňuje interpretom vyspievat početné a rozmanité ozdoby. Avšak nie všetky piesne z uvedených skupín majú rubatový charakter. Môžeme sa v nich stretnút aj s piesňami mierne rýchlejšieho tempa, v ktorých je ozdobnost’ o niečo menej zastúpená. Na ukážku uvádzame baladu Plače djovča na doliňe (Príklad 40).

S početnými rozmanitými ozdobami sa stretávame aj v novej piesňovej kultúre. Nie sú však zastúpené do takej miery ako v prechodnej štýlovej medzivrstve piesní. Najzastúpenejšie sú predovšetkým v staršej vrstve harmonických piesní (44 záznamov). ${ }^{69} \mathrm{~V}$ nových harmonických piesňach sú skôr výnimkou a pravidelne sa viažu na piesne pomalšieho tempa a charakteru. Ako príklad staršej harmonickej piesne pomalého tempa s početným zastúpením ozdôb uvádzame lúbostnú pieseň Cesta hore, dru-

\footnotetext{
67 Tamtiež.

68 URBANCOVÁ, Hana: Trávnice - lúčne piesne na Slovensku. Ku genéze, štruktúre a premenám piesňového žánru. Bratislava : AEP, 2005, s. 141, 292.

69 LOMEN, Ref. 3, s. 204-207.
} 
há dole (Príklad 26), svadobnú pieseň Zaspievaj slávičku (Príklad 41) či baladu F širom polì hruška stojí (Príklad 42). Ozdoby sa môžu vyskytnút aj v piesňach rýchlejšieho charakteru, aj ked’ nie v takom početnom zastúpení. Takou je napríklad lúbostná pieseň Dám tì milá tri dukáti (Príklad 43). V nových harmonických piesňach (98 záznamov) sa s drobnými ozdobami stretávame už v ovela menšom rozsahu, kedže v nich prevažuje rýchle, tanečné tempo. Podobnú situáciu zaznamenali mad’arskí etnomuzikológovia. ${ }^{70}$ Ako príklad môžeme uviest zbojnícku pieseň Švárno djovča húske páslo (Príklad 44) a lúbostné piesne Jasná hviezda do ulìci svietila (Príklad 45) a Pola nás, pola nás (Príklad 46). Ozdobnost' sme zaznamenali aj pri nových harmonických piesňach západoeurópskeho typu (18 záznamov). Tempo týchto piesní je vo všeobecnosti mierne až stredne rýchle. Domnievame sa preto, že ozdobnost̉ je v značnej miere podmienená interpretačnou zručnostou jednotlivých spevákov. Ako príklad ozdobnosti zastúpenej v piesňach západoeurópskeho typu uvádzame balady Bou edom Štefam král (Príklad 47) a Medzi dvoma brehami (Príklad 48). Obidve piesne sme zaznamenali v podaní Jána Pecníka z najstaršej generácie, ktorý vo svojom prednese vo všeobecnosti aplikoval početné ozdoby.

Z uvedených príkladov vyplýva, že zatial' čo stará piesňová kultúra obsahuje minimum ozdôb bez ohladu na tempo prednesu, ich výskyt $\mathrm{v}$ piesňach z prechodnej štýlovej medzivrstvy a novej piesňovej kultúry je podmienený predovšetkým tempom piesní a interpretačnou zručnostou speváka. Výnimku medzi ozdobami tvoria početné glissandá a hlasové vibrato, ktoré sú vo väčšej alebo menšej miere zastúpené vo všetkých hudobnoštýlových vrstvách.

\section{Transkripcia piesní a zápis ozdôb}

Zápis ludových piesní prešiel niekolkými vývojovými etapami. Vo svojich začiatkoch (v prvej polovici 19. storočia) sa slovenskí zberatelia sústredili najmä na zápis textovej zložky piesní, podobne ako zberatelia $\mathrm{v}$ iných európskych regiónoch. Výsledkom ich zberatel'ského záujmu sú dve významné zbierky textov slovenských ludových piesní: Písně světské lidu slovenského v Uhřich (I. zväzok 1823, II. zväzok 1827) Pavla Jozefa Šafárika a Jána Kollára ${ }^{71}$ a Národnie spievanky Jána Kollára (I. diel 1834, II. diel 1835)..$^{72}$ V Starej Pazove podobnú textovú zbierku piesní zostavil Michal Filip v závere prvej polovice 20. storočia. Jeho zbierka obsahuje takmer 400 zápisov piesní, pričom svojím zameraním výlučne na piesňové texty bola v uvedenom období už neaktuálna. ${ }^{73}$ Postupne začali zberatelia zapisovat nielen texty, ale aj nápevy piesní. Avšak nie všetci mali postačujúce odborné hudobné znalosti. Zápisy sa často uskutočňovali priamo

70 PAKSA, Katalin: Ornamentation System of the Melodies in Volume VI of Corpus Musicae Popularis Hungaricae. In: Studia Musicologica Academiae Scientiarum Hungaricae, roč. 22, 1980, č. $1 / 4$, s. 139.

71 KOLLÁR, Ján - ŠAFÁRIK, Pavel Jozef: Piesne svetské ludu slovenského v Uhorsku. Ed. Ladislav Galko. Bratislava : Tatran, 1988.

72 KOLLÁR, Ján: Národnie spievanky. Diel I. - II. Ed. Eugen Pauliny. Bratislava : Slovenské vydavatel'stvo krásnej literatúry, 1953.

73 O niekol'ko desiatok rokov neskôr k nim pripojil nápevy učitel matematiky Juraj Miškovic. Ref. 60. 
na mieste, bez možnosti neskoršej reprodukcie spevu. Nezriedka preto prichádzalo k simplifikácii a redukcii melodického zápisu, a to najmä pri zdobenom (alebo „cifrovanom ${ }^{\text {“74) }}$ speve. V rámci pazovských zápisov piesní je ukážkou takýchto záznamov rukopisná zbierka Benjamína Kamenára, ktorá ani jedným zápisom nedokumentuje ozdobný spev. Na základe zápisov iných autorov sa však domnievame, že ozdobný spev na začiatku 20. storočia musel byt súčastou tradičného piesňového repertoáru v tejto lokalite. Podobne na tom boli aj zápisy tradičných piesní z územia Mad’arska, ktoré Z. Kodály označil ako neadekvátne, a preto nepoužitel’né pri výskume. ${ }^{75}$

K značnému posunu $\mathrm{v}$ zápisoch (nielen ozdobného) spevu prispelo využitie fonografu na prelome 19. a 20. storočia. Fonograf ako prostriedok zvukovej dokumentácie použili viacerí významní bádatelia, napríklad Zoltán Kodály (1882 - 1967), ${ }^{76}$ Béla Bartók (1881 - 1945), ${ }^{77}$ Leoš Janáček $\left(1854\right.$ - 1928). ${ }^{78}$ Na Slovensku ho ako prvý v praxi uplatnil etnograf Karol Anton Medvecký (1875 - 1937) v roku 1901. Pomocou fonografu K. Medvecký zaznamenal tri desiatky piesní z Detvy s ambíciou dokumentovat lokálny piesňový repertoár a jeho špecifiká. Medveckého pôvodným zámerom bolo uskutočnit zvukový záznam hry na fujare, ktorej notový zápis považoval za náročný, ale takýto zvukový záznam sa mu zrealizovat nepodarilo. Prvotným motívom bola teda zvuková dokumentácia transkripčne náročného hudobného prejavu. ${ }^{79}$ Zvukový záznam vytvoril vhodné podmienky na detailnejší zápis tradičnej hudby a spevu. Ambície adekvátne transkribovat’ vokálny prejav sme si mohli všimnút pri väčšine zápisov pazovských piesní realizovaných profesionálnymi zberatelmi, ktorých sme uviedli vyššie. Podobný postup sme sa snažili využit pri našich vlastných transkripciách.

Zápis pazovských piesní je mimoriadne náročný. Každý zberatel', ktorý sa stretol s ozdobným spevom, mal podobné skúsenosti. ${ }^{80}$ Mnohí autori v minulosti zdôraz-

$74 \quad$ PLICKA, Karol: Eva Studeničová spieva. Turčiansky Svätý Martin : Matica slovenská, 1928, s. 59.

75 KODÁLY, Zoltán - ERDÉLY, Stephen: Pentatonicism in Hungarian Folk Music. In: Ethnomusicology, roč. 14, 1970, č. 2, s. 236.

76 ERDÉLY, Stephen: Complementary Aspects of Bartók's and Kodály's Folk Song Researches. In: Bartók and Kodály Revisited. Indiana University Studies on Hungary 2. Budapest : Akadémiai Kiadó, 1987, s. 79-98. NELSON, Taylor David: Béla Bartók: The Father of Ethnomusicology. In: Musical Offerings, roč. 3, 2012, č. 2, s. 75-89. RÁNKI, György (ed.): Bartók and Kodály Revisited. Indiana University Studies on Hungary 2. Budapest : Akadémia Kiadó, 1987.

77 NELSON, Ref. 76. Béla Bartók [Heslo.] In: STANLEY, Sadie - TYRREL, John (eds.): The New Grove Dictionary of Music and Musicians. Zväzok 2. New York : Oxford University Press, 2001, s. 787-810. BARTÓK, Béla: Prečo a ako máme zbierat ludovú hudbu? (1936) In: BARTÓK, Béla: Postrehy a názory. Ed. Oskár Elschek. Bratislava : Štátne hudobné vydavatel'stvo, 1965, s. 191-211.

78 TONCROVÁ, Marta: Fonograf ve folkoristické práci Leoše Janáčka a jeho spolupracovníků. In: Nejstarši zvukové záznamy moravského a slovenského lidového zpěvu. Ed. Jiří Plocek. Brno : Genesis, 1998, s. 37-46.

79 URBANCOVÁ, Hana: Z histórie prvých fonografických nahrávok na Slovensku. Korešpondencia Karola Medveckého a Andreja Kmet̉a z roku 1901. In: Slovenský národopis, roč. 54, 2006, č. 1, s. 5-28. URBANCOVÁ, Hana: K obsahovej rekonštrukcii prvých fonografických nahrávok slovenskej ludovej hudby. In: Multimediálna spoločnost’ na prahu 21. storočia - jej kultúra, umenie, hudba a neprekonané problémy. Ed. Oskár Elschek. Bratislava : Centrum mediálnej kultúry pri Ústave hudobnej vedy SAV; ASCO Art \& Science, 2005, s. 206-225.

80 SUCHOFF, Benjamin (ed.): Yugoslav Folk Music. Serbo-Croatian Folk Songs and Instrumental Pieces from the Milman Parry Collection by Béla Bartók and Albert B. Lord. Vol. 1. New York : State University of New York, 1978. 
ňovali, že hudobná analýza piesňového materiálu ani jej následné vyhodnotenie sa nemôžu uskutočnit bez dôsledného prepisu (transkripcie) piesní zo zvukovej do notovej podoby. ${ }^{81}$ Transkripcie piesní zo zvukového záznamu mali byt' podla možností čo najvernejšie prenesené do podoby grafickej (notačnej). ${ }^{82} \mathrm{~V}$ tejto súvislosti stručne zhrnieme postup, ktorým sme sa riadili pri prepise nami dokumentovaného piesňového materiálu.

Na rozdiel od predchádzajúcich autorov, ktorých sme uviedli vyššie pri transkripcii piesní, sme sa v značnej miere riadili notačným systémom Bélu Bartóka. Pri zápise Bartók zohladnil všetky zložky piesne: melodickú, rytmickú, metrickú, tempovú, ozdobnú, textovú. Vychádzal z adaptovanej klasickej európskej notácie, ktorú rozšíril o používanie rôznych značiek. Tieto značky zaznamenávajú predovšetkým výškové a rytmické odchýlky, ale aj ozdoby, kĺzanie či viazanie jednotlivých tónov a v súčasnosti sú štandardnou súčastou etnomuzikologickej transkripcie. Čo sa týka aplikácie ozdôb, skupinu tónov, ktoré vytvárajú melizmu, Bartók spájal oblúkom. Malými prírazmi a odrazmi označil tóny, ktoré sú menej závažné, menej prízvukované, a ktoré by sa mali spievat’ „letmo“. Na označenie kĺzania Bartók využil dlhú vlnovku smerujúcu nahor alebo nadol, pričom rozlíšil až 6 variantov glissánd. ${ }^{83}$

Pri zaznamenávaní tempa piesní miestami udával presnú metricko-rytmickú hodnotu, $\mathrm{v}$ prípade rázneho tanečného rytmu používal značenie tempo giusto, pri melódiách bez pravidelného rytmického pulzu udával značenie parlando, parlando rubato či rubato. V našich zápisoch je pri metricky členitel’ných piesňach uvedená metrorytmická hodnota, pri piesňach s ametrickým nápevom a pomalým tempom je uvedené iba trvanie prvej strofy.

Medzi najkomplikovanejšie patrili zápisy piesní s mimoriadne bohatým zastúpením ozdôb. Podobne ako B. Bartók či K. Plicka aj my sme pri zápise týchto piesní dospeli k záveru, že nie je možné zachytit pri transkripcii úplne presne všetko, čo spevák zaspieval. ${ }^{84}$ Najkomplikovanejšie na zápis boli rubatové ametrické nápevy, najmä pre pomalé tempo a množstvo ozdôb. Aj Kodály konštatoval, že pri takomto zápise sa možno stretnút’ s nejednoznačnostou pri prepise piesní, pričom sa vyjadril k rytmickej stránke ich zápisu:

„As to the slow melodies, their exact transcription is quite difficult because their note values are irrational, not easy to express in our present notation system. Each attempt is more or less an approximation. " ${ }^{\text {"5 }}$

[Pokial ide o pomalé melódie, ich presná transkripcia je pomerne náročná, pretože ich rytmické hodnoty sú iracionálne (neuchopitel’né) a nie je jednoduché ich vyjadrit’ v našom súčasnom notačnom systéme. Každý pokus je viac alebo menej približný.]

81 KODÁLY - ERDÉLY, Ref. 75, s. 228-242.

82 SUCHOFF, Ref. 80, s. 3-20.

83 BARTÓK, Béla: Slovenské ludové piesne. Zväzok 1. Ed. Oskár Elschek, Alica Elscheková. Bratislava : Hudobné centrum; VEDA SAV, 2019, s. 103-107.

84 PLICKA, Ref. 1, s. 12-13. SUCHOFF, Ref. 80, s. 3.

85 KODÁLY - ERDÉLY, Ref. 75, s. 232. 
S podobnou situáciou sme sa stretli aj pri zápise melodickej a rytmicko-metrickej stránky piesní, ako aj pri zápise ozdôb. Mimoriadne zložitý prednes piesní neumožňuje tzv. presnú transkripciu. Preto sa môže stat', že tá istá pieseň v podaní toho istého interpreta $\mathrm{v}$ zápisoch dvoch etnomuzikológov môže obsahovat transkripčné varianty či odchýlky, dokonca verzie. Napriek našej snahe čo najvernejšie a najpresnejšie zachytit’ melodickú, rytmickú, metrickú a ozdobnú stránku týchto piesní pripúštame v detailoch alternatívu ich zápisu v transkripcii iného etnomuzikológa.

Ak sme zdokumentovali viaceré záznamy jednej piesne v podaní odlišných informátorov, každý záznam sme, pochopitelne, transkribovali osobitne, vrátane nápevu aj textu piesne. Zároveň sme zaznamenávali medzistrofickú variabilitu. Cielom bolo zachytit rôzne melodické a rytmické varianty, ktoré speváci uplatnili. Majstrami takýchto variačných postupov boli najmä speváci z najstaršej a strednej generácie.

Pri transkripcii sme sa riadili súborom notačných pravidiel, ktoré sú súčastou prispôsobenej (adaptovanej) európskej notácie. ${ }^{86} \mathrm{Na}$ záver tejto kapitoly prinášame prehlad grafických symbolov, ktoré sme podla charakteru pazovského piesňového repertoáru využili pri našej vlastnej transkripcii, pričom sme vychádzali zo systému B. Bartóka:

$\uparrow$ - intonované o trochu vyššie

$\downarrow$ - intonované o trochu nižšie

- o niečo dlhšie (ale nie o polovicu trvania rytmickej hodnoty)

$\smile$ - o niečo kratšie (ale nie o polovicu trvania rytmickej hodnoty)

$x \quad$ - tón neurčitej výšky

- glissando smerujúce nahor alebo nadol

- hlasové vibrato

Uvedené grafické symboly aspoň čiastočne pomáhajú pri detailnejšom zápise komplikovaného prednesu tradičných piesní. V nasledujúcej kapitole sa budeme venovat’ samotným ozdobám v tradičnom pazovskom speve a pokúsime sa ich bližšie charakterizovat.

\section{Klasifikácia ozdôb v tradičnom speve Starej Pazovy}

V súčasnosti existuje množstvo odborných publikácií, ktoré sa venujú problematike ozdôb z rôznych hladísk, napríklad z pohladu hudobnej historiografie, hudobnointerpretačnej praxe, hudobnej teórie, hudobnej pedagogiky a didaktiky. Väčšina $z$ nich sa zaoberá ornamentikou v klasickej inštrumentálnej alebo vokálnej hudbe a ich správnou interpretáciou. ${ }^{87}$ Hudobná teória rozlišuje tri kategórie ozdôb:

${ }^{86}$ ELLINGSON, Ter: Transcription. In: MYERS, Helen (ed.): Ethnomusicology. An Introduction. (The New Grove Handbooks in Music.) London : Macmillan, 1992, s. 110-152. BARTÓ, Ref. 83.

87 KUHN, Max: Die Verzierung-Kunst in der Gesangs-Musik des 16. bis 17. Jahrhunderts (15351650). Wiesbaden : Sändig, 1969. GJERDINGEN, Robert O.: Music in Galant Style. New York : Oxford University Press, 2007. MATHER, Betty Bang - LASOCKI, David: Free ornamentation in woodwind music, 1700-1775: an anthology with introduction. New York : McGinnis and Marx, 
1. ozdoby, ktoré sú improvizované počas predvedenia skladby;

2. ozdoby, ktoré sú označené pomocou notačných symbolov;

3. ozdoby, ktoré vytvoril („predpísal“) skladatel. ${ }^{8}$

Ani jedna z uvedených kategórií však nezodpovedá klasifikácii, ktorá by sa mohla vztahovat’ na ozdobný spev v Starej Pazove. Podla názorov niektorých bádatelov ozdoby $\mathrm{v}$ tradičnom piesňovom repertoári nie sú vždy improvizované. ${ }^{89}$ Zásadný rozdiel spočíva $\mathrm{v}$ samotnom princípe predvedenia ozdôb. Zjednodušene povedané, zatial čo v klasickej hudbe sa interpreti snažia čo najpresnejšie predviest̉ zapísané („predpísanéc) ozdoby, etnomuzikológ sa snaží čo najdôslednejšie zapísat’ („opísat") ozdoby, ktoré spevák v danom momente zaspieval..$^{90}$ Ich zápis často nekorešponduje so zápisom ozdôb, ktoré ponúka notačný systém klasickej európskej hudby. Ani samotný spevák nevie pri opakovanej interpretácii znenie týchto ozdôb reprodukovat totožne. Jedným z dôvodov je samotný vokálny prejav a jeho špecifiká. Zároveň aj „individuálny prístup interpreta k piesňovému materiálu, jeho tvorivost’, muzikálnost’ a cit, často genetický základ týchto vlastností sú pri ozdobnom speve takmer samozrejmostou. “91 Pri dôslednejšej analýze ozdôb, pri zistovaní ich melodického pohybu môže byt preto mimoriadne nápomocná zvuková analýza. ${ }^{92}$

Pozoruhodný pohlad na ozdobnost' má americký etnomuzikológ kórejského pôvodu Byong Won Lee. Odlíšil dve kategórie ozdôb z hladiska ich funkcie:

1. Ozdoby, ktoré sú obohatením hlavnej, nosnej melódie, resp. hlavných, nosných tónov melodickej línie piesne alebo skladby. Takáto funkcia je príznačná pre západnú klasickú hudbu. V jej rámci sú ozdoby presne vypísané alebo vyznačené určitým symbolom. Od interpreta sa očakáva ich presné predvedenie z hladiska výšky tónov a rytmu (časový aspekt) tónov.

2. Odlišnú funkciu zastávajú ozdoby, ktoré majú prakticky rovnocenné miesto s „hlavnými“ tónmi melodickej línie. Často sú integrálnou súčastou melódie a nie

1976. KITE-POWELL Jeffery: Ornamentation in Sixteeenth-Century Music. Publications of the Early Music Institute. Bloomington : Indiana University Press, 2007. DICKEY, Bruce: Ornamentation in early-seventeenth-century Italian music. Bloomington : Indiana University Press, 2012. BUCHLER, Michael: Understanding Ornamentation in Atonal Music. In: The ICMPC-ESCOM 2012 Joint Conference - 12th Biennial International Conference for Music Perception and Cognition; 8th Triennial Conference of the European Society for the Cognitive Sciences of Music. Published by: Aristoteleio Panepistīmio (Department of Musical Studies), Thessalonikī, Greece, 2012, s. 171-175. BAKIREVA, Gunel: The History of Ornamentation Development in Music, Principles of its Formation and Performance Style. In: Вісник Київського національного університету культури і мистецтв. Серія: Музичне мистецтво, rос̌. 3, 2020, с̌. 2, s. 169180. Dostupné na internete: <http://musical-art.knukim.edu.ua/> ( cit. 2021. 01. 18).

88 RAWLINS, T. Joseph: Ornaments and Ornamentation, Some Practical Observations for Performers. In: Journal of singing: The official journal of the National Association of Teachers of Singing, roč. 61, 2004, č. 1, s. 35-49.

89 PLICKA, Ref. 1, s. 12.

90 SEEGER, Charles: Prescriptive and descriptive music-writing. In: Musical Quarterly, roč. 44, 1958, č. 2, s. 184-195.

91 MICHALOVIČ, Ref. 20, s. 87-94.

92 Napr. URBANCOVÁ, Hana: Ťahavé žalostné piesne „phurikane gila“" z repertoáru slovenských Rómov. Hudobná analýza a kategórie hudobného štýlu. In: Ethnomusicologicum V. Ed. Hana Urbancová. Bratislava : Ústav hudobnej vedy SAV, 2017, s. 37-41. 
je jednoduché ich oddelit od nosnej/hlavnej melodickej línie. Takéto nejasné hranice medzi melódiou a ozdobami predstavujú bežný jav v hudobných tradíciách, ktoré sa prenášajú z generácie na generáciu ústne (oral transmission). ${ }^{93}$

Z uvedeného vyplýva, že klasifikácia ozdôb, ktorú pozná západná európska hudba, zdaleka nepostačuje na rozlišovanie a triedenie ornamentov vo väčšine tradičných piesňových kultúr etník, v ktorých sú bohato zastúpené. $\mathrm{V}$ súčasnosti neexistuje záväzný klasifikačný systém ozdobného spevu, ktorým by sme sa mohli riadit pri jeho analýze. Viacerí etnomuzikológovia sa $\mathrm{v}$ minulosti snažili vyrovnat' s ozdobami charakteristickými pre tradičné piesne svojho vlastného etnika. ${ }^{94}$ Väčšinou opísali jednotlivé ornamenty a ich interpretáciu. Na pomenovanie určitých typov ozdôb si vypožičiavali termíny z hudobnej teórie. Jednotlivé ozdoby, ktoré majú v európskej hudobnej teórii rovnaké pomenovania či symboliku (napríklad rôzne prírazy, odrazy, skupinky nôt a podobne), sa v tradičnom vokálnom prejave vo svojej podstate môžu ovela viac diferencovat. Práve toto považujeme za podstatu a osobitost̉ etnomuzikologického zápisu tradičného ozdobného spevu.

$\mathrm{Z}$ uvedeného hladiska sú pre nás najzaujímavejšie práce madarskej etnomuzikologičky Katalin Paksa, ktorá sa ozdobám v madarských ludových piesňach venovala $\mathrm{v}$ štyroch štúdiách: Ornamentation System of the Melodies in Volume VI of Corpus Musicae Popularis Hungaricae (1980), ${ }^{95}$ Pentatonic Melodies with a Narrow Range in Hungarian and Chuvash Folk Music (1984), ${ }^{96}$ Line Starting Ornaments in the Hungarian Folk Song (1987), ${ }^{97}$ Connection of Style and Dialect in the Ornamentation of Hungarian Folksongs (1992). ${ }^{98}$ Najdôslednejšie sa K. Paksa zaoberala ozdobami v prvej spomenutej štúdii, ktorá je zároveň najrozsiahlejšia. Autorka tu analyzovala odlišné ozdoby a ich výskyt v rozmanitých piesňových typoch, ktoré sa nachádzajú v zbierke piesní Corpus Musicae Popularis Hungaricae VI. ${ }^{99}$

Štúdia je rozčlenená na dve časti. Prvá sa zoberá výskytom ozdôb v jednotlivých oblastiach Rakúsko-Uhorska (okrem iných lokalít autorka spomína región Sriem, ktorého súčastou je aj Stará Pazova). Skúmaný materiál predstavoval repertoár v rozsahu 685 melódií, v rámci ktorých autorka vymedzila 14 melodických typov. Zároveň s nimi charakterizuje aj ozdoby, ktoré sa v nich vyskytujú. Podrobne ich opisuje, približuje ich uplatnenie v melódii, vyznačuje lokality, v ktorých sa takéto piesňové typy (a s nimi aj

93 BYONG-WON, Lee: The Ornaments in Traditional Korean Music. Structure, Function and Semantics. In: Ssi-ol. Almanach der Internationalen Isang Yun Gesellschaft e. V. Wallter-Wolfgang Sparrer ed. München : Internationalen Isang Yun Gesellschaft e. V, 1998-1999, s. 59-66.

94 Napr. ELLIS, Catherine Joan: Ornamentation in Australian Vocal Music. In: Ethnomusicology, roč. 7, 1963, č. 2, s. 88-95. PAKSA, Ref. 70, s. 137-185. PAKSA, Katalin: Line Starting Ornaments in the Hungarian Folk Song. In: Studia Musicologica Academiae Scientiarum Hungaricae, roč. 29, 1987, č. 1/4, s. 219-236. BYONG-WON, Ref. 93.

95 PAKSA, Ref. 70, s. 137-185.

96 PAKSA, Katalin: Pentatonic Melodies with a Narrow Range in Hungarian and Chuvash Folk Music. In: Studia Musicologica Academiae Scientiarum Hungaricae, roč. 26, 1984, č. 1/4, s. 147-174.

97 PAKSA, Line Starting Ornaments in the Hungarian Folk Song, Ref. 94.

98 PAKSA, Ref. 62.

99 BARTÓK, Béla - KODÁLY, Zoltán: Corpus Musicae Popularis Hungaricae - A Magyar Népzene Tára - Collection of Hungarian Folk Music. VI. Népdaltípusok - Types of Folksongs 1. Ed. Pál Járdányi, Imre Olsvai. Budapest : Akadémiai Kiadó, 1973. 
ich ozdoby) vyskytujú. Pritom na označenie jednotlivých ozdôb nevyužíva terminológiu hudobnej teórie. Namiesto toho niekde hovorí o ozdobách „pred notou“ (príraz) alebo „za notou“ (odraz). Pravdepodobne tým autorka rozlišuje medzi skutočným prírazom/odrazom a ozdobou, ktorá sa na takéto útvary iba podobá. Na označenie počtu tónov v rámci jednej ozdoby využíva termíny monomická, binomická, trinomická ozdoba. V druhej časti sa autorka zaoberá výskytom ozdobnosti v strofe. K. Paksa prišla k poznatkom, že bohatá ozdobnost’ sa prejavuje iba na určitých miestach v rámci strofy, najčastejšie v záveroch taktov, v záveroch fráz alebo celej strofy. Taktiež skúma vztah ornamentov a akcentov, ornamentov a rytmu, všíma si ich melodický charakter a v závere štúdie sa stručne zmieňuje aj o vztahu medzi vokálnou a inštrumentálnou ozdobnostou. ${ }^{100}$

Klasifikáciu ozdôb konkrétne pri piesňovom repertoári Starej Pazovy uskutočnil aj Ladislav Leng. Ide o jedinú klasifikáciu v súvislosti s ozdobami v tejto lokalite. Leng rozlišuje dva typy ozdôb, s ktorými sa v Starej Pazove stretol: ozdoby povahy ornamentálnej a ozdoby povahy melizmatickej. Princíp ozdobnosti podla L. Lenga spočíva v interpretácii viacerých až mnohých výškovo identifikovatelných tónov na jednu slabiku, resp. na jeden vokál, výnimočne aj na znelú spoluhlásku. Medzi ozdoby povahy ornamentálnej Leng zaradil odrazy, viazanie dvoch i viacerých tónov trvaním rovnocenných i nerovnocenných, viazanie skupiniek, jednoduchý náraz a iné. Medzi melizmatické ozdoby autor zaradil glissandové spájanie dvoch výškovo rozdielnych tónov, interpretačné akcenty na koncových znelých spoluhláskach a lokálne charakteristické vokálne vibrato. ${ }^{101}$ Toto členenie je zaujímavé a nezvyčajné aj vo svetle toho, že vibrato a glissandá sa nepovažujú vo všeobecnosti za ozdoby (ako sme vyššie naznačili). Leng ich zaradil do samostatnej skupiny. Za melizmatické ich považuje pravdepodobne preto, že zvukové kontinuum môžu obsahovat aj pevné tónové výšky pri prednese. Hlasové vibrato považoval za mimoriadne dôležitú súčast’ pazovských piesní, o čom svedčí aj skutočnost', že ho ako jediný autor pri zápise dôsledne rozpisoval. Domnievame sa, že zaradením glissanda a vibrata do samostatnej skupiny ozdôb chcel Leng zrejme poukázat na ich odlišnú podstatu v porovnaní s dalšími ozdobami.

Pri našej vlastnej klasifikácii sa budeme len čiastočne riadit systémom, ktorý využíva K. Paksa, kedže ide odlišný výskum: Paksa skúmala typy piesní v rôznych lokalitách a na základe spoločných znakov odvodila 14 piesňových typov s ozdobami rozličného charakteru. Navyše, na rozdiel od nášho prípadu pracuje už s transkripciami piesní, ktoré realizovali iní autori.

Naším cielom bude opísat jednotlivé ozdoby, s ktorými sa možno stretnút v piesňovom repertoári jednej lokality. O ozdobách v Starej Pazove budeme hovorit predovšetkým ako o ozdobných typoch, pričom len naznačíme ich podobnost's ozdobami, tak ako ich definuje hudobná teória. $Z$ nášho pohladu je nutné venovat sa aj glissandám a hlasovému vibratu, nakol'ko sú neodmyslitel’nou súčastou pazovského spevu. O hlasovom vibrate ani o glissande však nebudeme hovorit ako o ozdobných typoch. Po-

100 PAKSA, Ref. 70, s. 183.

101 LENG, Ref. 11, s. 348-349. 
dobne ako Leng aj my považujeme za správne oddelit tieto útvary od ostatných ozdôb. Nepovažujeme však za nevyhnutné označit ich ako melizmatické ozdoby.

\section{Typy ozdôb a ich charakteristika v tradičnom speve Starej Pazovy}

Skôr než pristúpime k jednotlivým typom ozdôb, vyjadríme sa k uplatneniu hlasového vibrata a glissanda v tradičných piesňach Starej Pazovy v súčasnosti.

Hlasové vibrato využívali pri speve všetci speváci takmer vo všetkých piesňach. Zaznamenali sme ho v rámci dlhších rytmických hodnôt, akými sú celá, polová s bodkou, polová, štvrtová s bodkou, prípadne štvrtová hodnota. Častejšie sa vibrato objavovalo $\mathrm{v}$ piesňach pomalého alebo mierne rýchleho charakteru. V našich transkripciách sme vibrato nerozpisovali, iba sme ho označili príslušným značením (vlnovkou nad príslušnou notou). V zvukovom zázname pri jednotlivých nahrávkach v podaní niektorých spevákov je však jeho intenzita mimoriadne silná. Takéto predvedenie môže u poslucháča vyvolat pochybnost', či v skutočnosti ide o vibrato alebo o trilok. Hranica medzi nimi v prednese jednotlivých spevákov nie je vždy jasná. Ako príklad môžeme uviest̉ pieseň v podaní Vladimíra Žolnaja (nar. 1964), ktorý v speve často využíva mimoriadne intenzívne vibrato $\mathrm{z}$ hladiska dynamiky. Z hladiska tempa je toto vibrato predvedené menej intenzívne. Domnievame sa, že aj vdaka tomu je zdôraznený jeho význam. Na účely tejto štúdie sme ho rozpísali:

\section{Ukážka 1:}

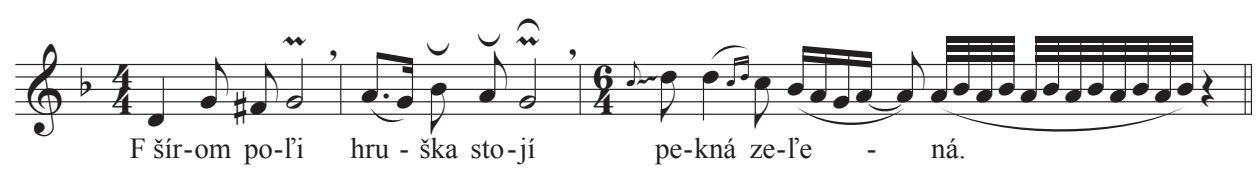

V pazovskom tradičnom speve je velmi často zastúpené glissando. S oblubou ho využívajú speváci a speváčky všetkých vekových kategórií, najčastejšie sme ho však postrehli u spevákov zo staršej a strednej generácie. Vyskytuje sa v piesňach rubatového charakteru, v piesňach pomalého, mierneho či mierne rýchlejšieho tempa. $\mathrm{V}$ piesňach tanečného charakteru sme glissandá zaznamenali ojedinele. Patričnú pozornost’ výskytu glissánd venoval aj B. Bartók, ktorý rozlíšil niekol'ko druhov. ${ }^{102}$

Glissandá v Starej Pazove sme odlíšili na základe výškového rozpätia a podla spôsobu interpretácie. Z hladiska ambitu sme zaznamenali 4 druhy glissánd:

1. glissando v rozsahu velkej alebo malej sekundy v oboch smeroch (častejšie vel'kej);

2. glissando v rozsahu vel'kej alebo malej tercie v oboch smeroch, častejšie však v smere descendenčnom (častejšie malej tercie); 
3. glissando v rozsahu čistej kvarty, ktoré má častejšie descendenčný charakter;

4. glissando v rozsahu čistej kvinty, ktoré má spravidla descendenčný charakter.

Najčastejšie sme zaznamenali glissandá v rozpätí sekundy a kvarty. Z hladiska ambitu sme všetky glissandá zaznamenali v lúbostnej piesni Lastovienka lìeta.

\section{Ukážka 2:}

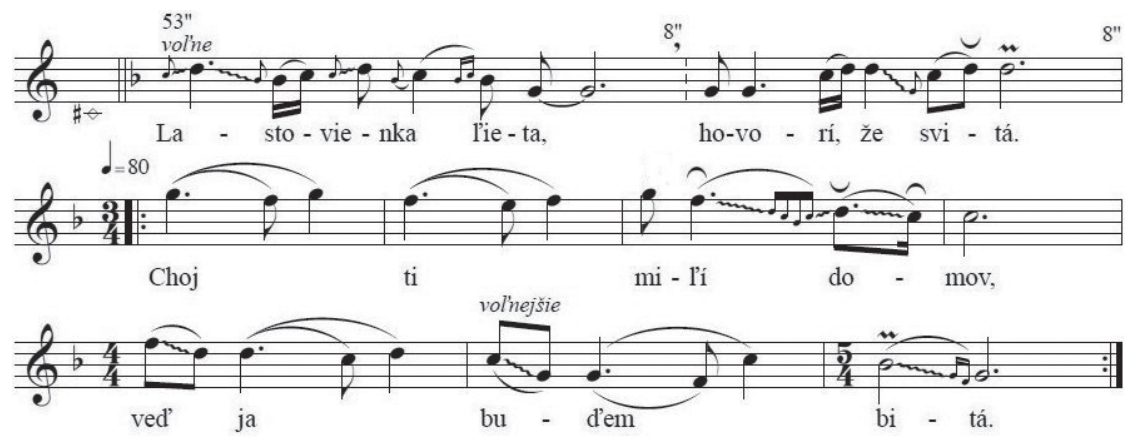

Okrem uvedených glissánd sa možno len ojedinele stretnút’ s ambitom väčšieho rozsahu. Takúto výnimku sme zaznamenali v svadobnej piesni Nad Dunajom dve hvjezdičke, kde speváčka použila glissando v rozsahu vel'kej sexty v oboch smeroch. Zároveň sa v tejto piesni objavuje aj pomerne zriedkavé ascendenčné glissando v rozsahu kvarty.

Ukážka 3:
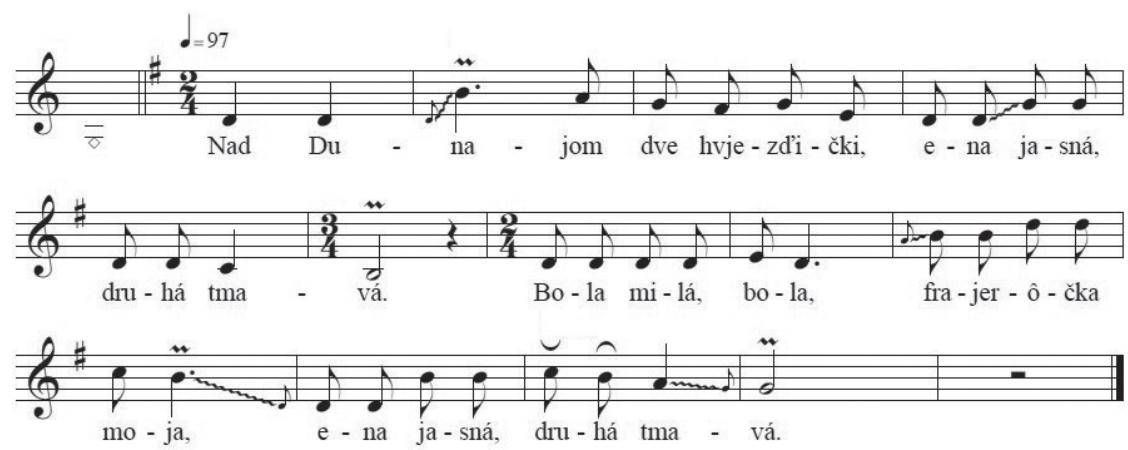

Z hladiska uplatnenia glissánd a ich ambitu je zaujímavá ukážka svadobnej piesne Ej, hoja, hoja v interpretácii Speváckej skupiny pazovských žien. Môžeme tu vidiet’ aplikáciu glissánd prakticky v celej piesni. Pred záverom piesne speváčky dokonca uplatnili glissando v rozsahu malej septimy. Ide o jedinečný prípad, s ktorým sme sa v pazovských piesňach už nestretli. 
Ukážka 4:

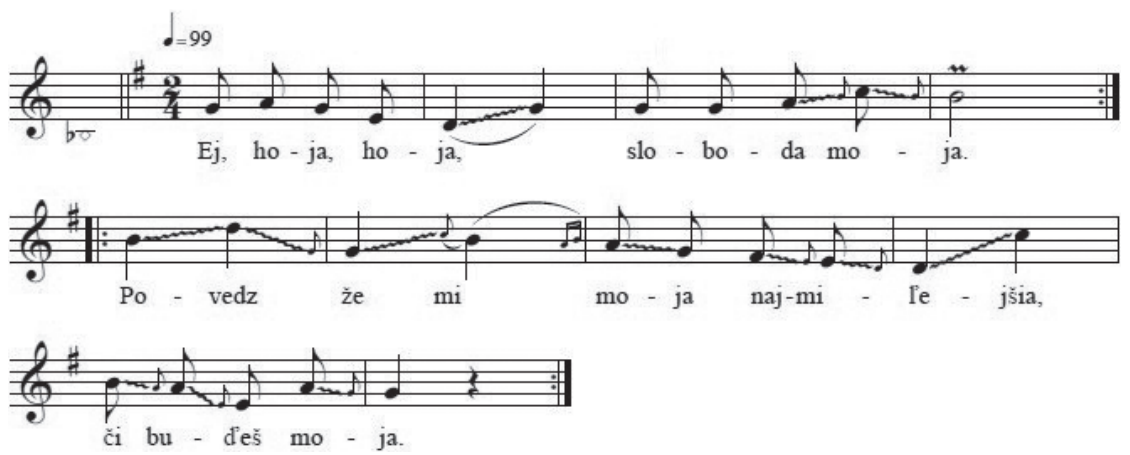

Podla spôsobu interpretácie sme rozlíšili niekolko druhov glissánd, pričom všetky môžu mat' ascendenčný aj descendenčný charakter:

a) glissando, ktoré vychádza $z$ určitej výšky a smeruje na určitú výšku; pre lepšiu orientáciu v zápisoch sme na označenie určitej výšky využili drobnú osminovú notu s príslušným glissandovým značením. Ide o najčastejší typ glissanda, s ktorým sa v pazovskom speve stretávame. Zaznamenali sme ho v rozsahu sekundy, tercie a kvarty. Sekundové glissandá tohto druhu sa pohybujú približne rovnako často $\mathrm{v}$ ascendenčnom aj descendenčnom smere. Glissandá v rozsahu tercie a kvarty majú častejšie descendenčný charakter.

Ukážka 5: Ukážka glissanda, ktoré vychádza z určitej výšky a smeruje na určitú výšku

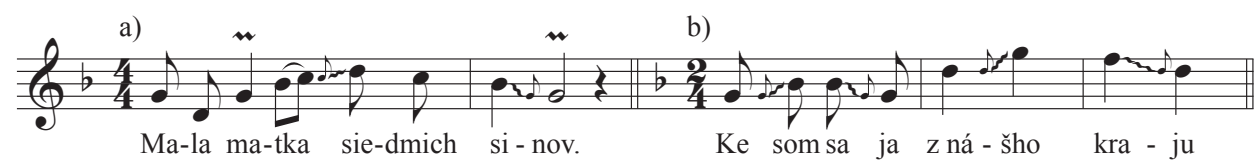

b) glissando prechodného charakteru, ktoré zachytáva zvukovú škálu niekolkých tónov a poltónov, vychádza $z$ určitej výšky, ale smeruje na neurčitú výšku. V praxi to znamená, že glissando sa môže končit’ o niečo vyššie alebo o niečo nižšie ako nasledujúci konkrétny tón, ktorý zaznie. Na určenie presného intervalového rozsahu tohto glissanda by bolo potrebné uskutočnit zvukovú analýzu. Najčastejšie sa objavuje medzi dvomi metricky členitelnými rytmickými hodnotami.

Ukážka 6: Ukážka glissanda smerujúceho z určitej výšky na neurčitú výšku

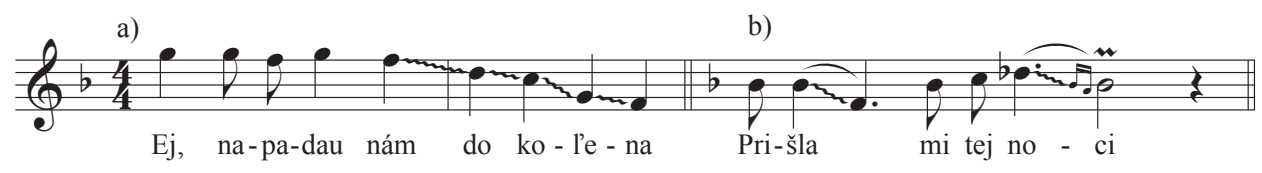

c) glissando, ktoré slúži ako intonačná opora. Začiatočný tón tohto glissanda je väčšinou vel'ká sekunda pod hlavným tónom. Zväčša sa nachádza na začiatku piesne alebo na začiatku melodickej frázy. 
Ukážka 7: Ukážka glissanda, ktoré slúži ako intonačná opora

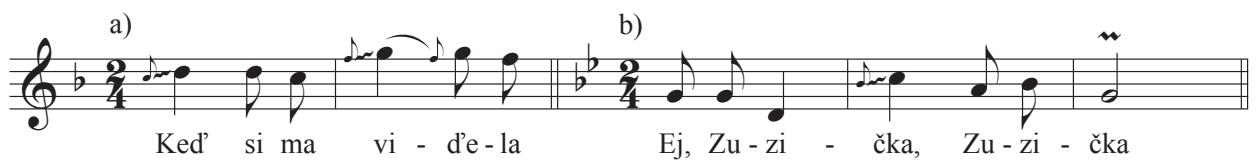

d) glissando, pri ktorom možno pomerne zretel’ne rozlíšit jednotlivé tóny, tie sú označené drobnými notami, spravidla sa vyskytuje v závere piesne, najčastejšie v rámci kvartového skoku. V piesňach tejto lokality sme sa s ním stretli len zriedka.

Ukážka 8: Ukážka glissanda, v ktorom zretel’ne zaznejú jednotlivé tóny

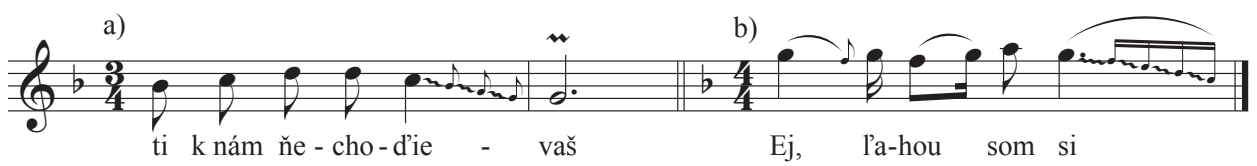

Ďalej sa budeme venovat jednotlivým typom ozdôb. V slovenských piesňach zo Starej Pazovy sme rozlíšili až 13 typov. Je nutné zdôraznit, že vyplynuli z našej vlastnej transkripcie piesňového materiálu. Uvedené typy sa pokúsime bližšie charakterizovat'. Ozdoby sa zväčša vyskytujú na dlhších rytmických hodnotách. Objavujú sa pred nimi alebo za nimi. Typy I až V opisujú ozdoby, ktoré sa objavujú pred hlavnou notou, typy VI až XI opisujú ozdoby vyskytujúce sa za hlavným tónom, v tomto prípade môže íst rovnako o tažké ako aj o lahké doby. V ukážkach využijeme len fragmenty z piesní, pričom pri niektorých $\mathrm{z}$ nich sme zámerne ponechali len ozdoby týkajúce sa konkrétnej ukážky pre lepšiu názornost'.

\section{Ozdoby pred melodickým tónom}

\section{Typ I}

Prvý typ môžeme charakterizovat’ ako ozdobu krátkeho trvania (najčastejšie osminového), ktorá sa vyskytuje pred hlavným tónom. Ide o monomickú103 ozdobu (obsahuje len jeden tón). Čiastočne sa podobá ozdobe, ktorú v hudobnej teórii označujeme ako príraz. V pazovských piesňach sa vyskytuje pomerne často, pričom sa s ňou častejšie stretávame v piesňach mierne rýchleho až rýchleho charakteru. Môže sa vyskytnút na prízvučnej aj na neprízvučnej dobe taktu. Viaže sa na tóny rôzneho trvania: polové, štvrtové, štvrtové s bodkou, osminové. Z hladiska ambitu má spravidla sekundový rozsah, pričom môže stúpat’ alebo klesat. Častejšie má stúpajúci charakter. Môže stát ako úplne samostatná ozdoba (Ukážka 9a, 9c), môže mat’ prechodný charakter (Ukážka 9b) alebo môže opakovat predchádzajúci tón (9d). Častejšie sú druhé dva prípady. Na ukážku uvádzame fragmenty z niekol'kých piesní, ktoré obsahujú uvedené ozdoby:

103 Podla terminológie etnomuzikologičky K. Paksa. PAKSA, Ref. 70. 
Ukážka 9:

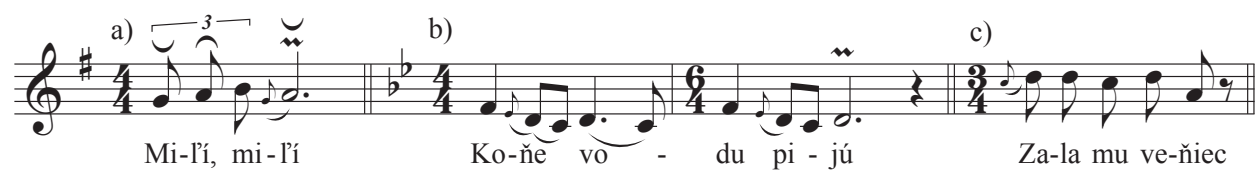

d)

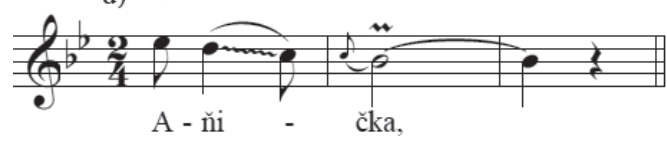

Typ II

Zriedkavou ozdobou je binomická obmena prvého typu: dve krátke ozdoby (najčastejšie osminové), ktoré nastupujú po sebe, obe v rozpätí sekundy pred hlavnou dobou. V porovnaní s klasickou (komponovanou) hudbou sa najviac podobá ozdobe, ktorú hudobná teória označuje ako dvojitý príraz. Pre jej zriedkavý výskyt nie je možné bližšie ju determinovat'.

\section{Ukážka 10:}

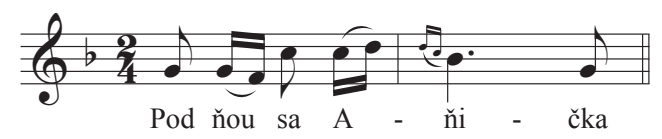

\section{Typ III}

Ojedinele sa môžeme stretnút aj s trinomickou obmenou tejto ozdoby, ktorá obsahuje tri krátke tóny (najčastejšie osminové) nastupujúce po sebe v rozpätí sekundy pred hlavným tónom. V porovnaní s klasickou hudbou sa najviac podobá ozdobe, ktorú hudobná teória označuje ako trojitý príraz. Nakolko sme ich výskyt zaznamenali len $\mathrm{v}$ dvoch piesňach, bližšia charakteristika tejto ozdoby nie je možná.

\section{Ukážka 11:}

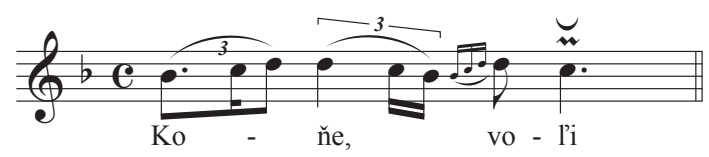

\section{Typ IV}

Velmi častá je binomická ozdoba, ktorá obsahuje dva krátke tóny (najčastejšie šestnástinového trvania) striedavého charakteru pred dobou. Môže sa podobat' ozdobe, ktorú hudobná teória označuje ako mordent (náraz). Podobne ako pri mordente aj pri tejto ozdobe je hlavný tón vystriedaný spodnou vel'kou alebo malou sekundou. Avšak trvanie týchto ozdôb si určuje samotný spevák. Uvedená binomická ozdoba sa najčastejšie objavuje pred štvrtovou rytmickou hodnotou alebo štvrtovou s bodkou. V podstate sa môže vyskytnút' v lubovolnom úseku piesne, na ktorejkolvek dobe v takte. Jej zastúpenie nájdeme $\mathrm{v}$ piesňach rozmanitého charakteru s rôznym tematickým zamera- 
ním a takmer vo všetkých hudobnoštýlových vrstvách. Jej využitie nie je podmienené tempom: objavuje sa v najpomalších piesňach, v piesňach mierneho tempa, mierne rýchleho tempa a rovnako aj v piesňach rýchlych, resp. tanečných.

\section{Ukážka 12:}

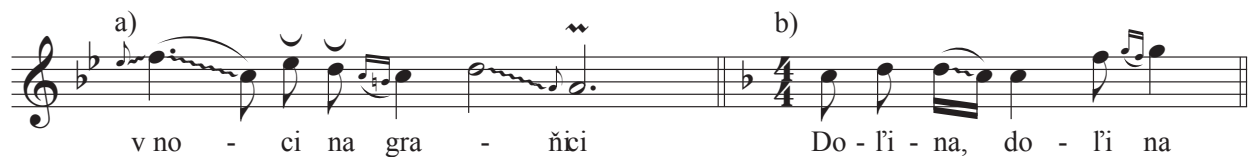

c)

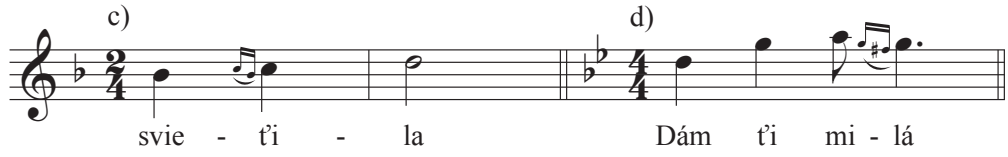

Typ V

Zriedkavou je ozdoba, ktorá predstavuje obmenu typu IV. Môže sa podobat nátrilu (obrátený mordent), ktorý poznáme z klasickej hudby. Jej princíp spočíva vo vystriedaní hlavného tónu vrchnou vel'kou alebo malou sekundou, pričom častejšia je vel'ká sekunda. Vyskytuje sa na prízvučnej alebo neprízvučnej dobe. Na rozdiel od predchádzajúcej táto ozdoba sa zväčša objaví na začiatku slabiky (nie je to však pravidlo). Zväčša sa viaže na osminové alebo štvrtové noty. Nachádzame ju v piesňach rôzneho charakteru a tempa.

Ukážka 13:

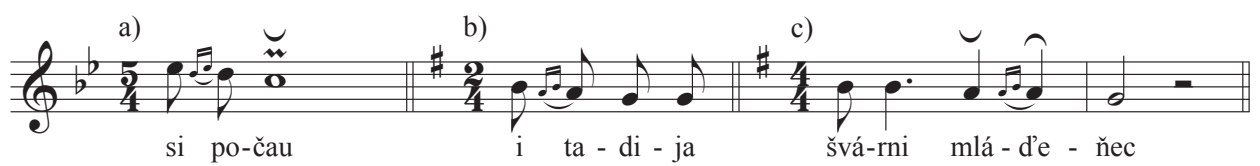

d)

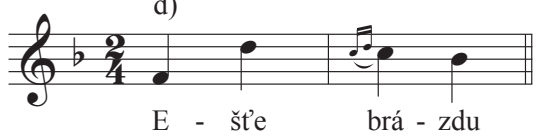

Ozdoby po melodickom tóne

\section{Typ VI}

V pazovských tradičných piesňach sú vo všeobecnosti frekventovanejšie ozdoby, ktoré sa nachádzajú za samostatnou dobou. Mimoriadne zastúpená je monomická ozdoba krátkeho trvania za tónom. Najčastejšie sme ju značili drobnou osminovou hodnotou. Môže pripomínat ozdobu, ktorú hudobná teória označuje termínom odraz. Nachádzame ju v pomalých piesňach aj v piesňach rýchlejšieho tempa. Zväčša má ambitus v rozsahu vel'kej alebo malej sekundy, pričom podstatne častejšou je vel'ká sekunda. Spravidla má descendenčný pohyb, vd’aka ktorému môže mat’ bud' prechodný, alebo striedavý charakter (sekundovým pohybom sa vráti k tónu, z ktorého vyšla). Vyskytuje sa ako na prízvučných, tak aj na neprízvučných dobách v takte. Najčastejšie sme ju zaznamenali v spojení so štvrtovými alebo osminovými hodnotami. 


\section{Ukážka 14:}

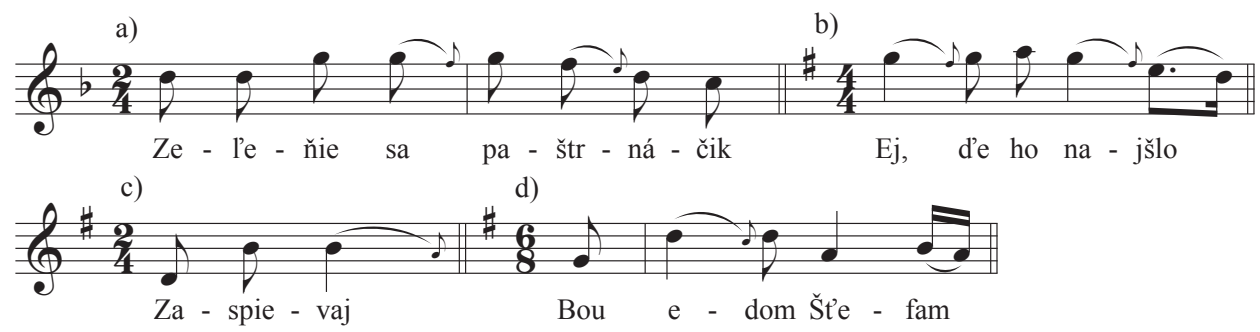

\section{Typ VII}

Ďalšia ozdoba, ktorá je obmenou typu VI, je o čosi vzácnejšia. Ide o binomickú ozdobu krátkeho trvania. Obsahuje dve drobné šestnástinové hodnoty, ktoré sú usporiadané po sekundách za sebou. Ozdoba má najčastejšie descendenčný pohyb. Ojedinele môže mat prechodný charakter, avšak nie vždy plní prechodnú funkciu medzi dvomi samostatnými tónmi (pozri ukážku 15a, 15b).

\section{Ukážka 15:}

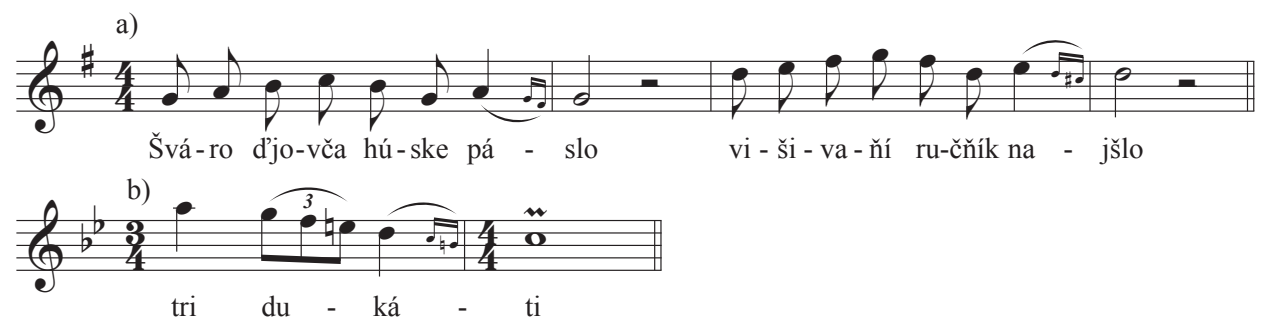

\section{Typ VIII}

Pomerne vzácna je ozdoba, ktorá pripomína trojitý odraz. Ide o trinomickú ozdobu (obsahuje tri tóny) krátkeho trvania. Väčšinou sme ju zapisovali v podobe drobných šestnástinových rytmických hodnôt. Často má descendenčný charakter. Obvykle nastupuje po tóne dlhšieho trvania (štvrtovej rytmickej hodnoty alebo štvrtovej s bodkou). Zväčša sme ju zaznamenali pri pentatonických piesňach pomalého, rubatového charakteru. $\mathrm{V}$ rámci nich sa môžu vyskytnút v lubovolnom úseku piesne na ktorejkolvek dobe. Môže plnit prechodnú funkciu medzi dvomi hlavnými dobami, môže anticipovat nastupujúcu dobu, alebo nemusí mat žiadne spojenie s nasledujúcou dobou.

\section{Ukážka 16:}

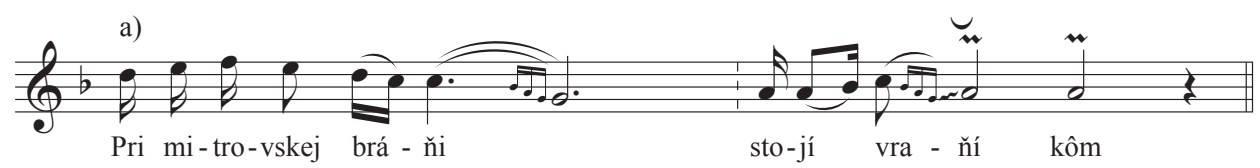




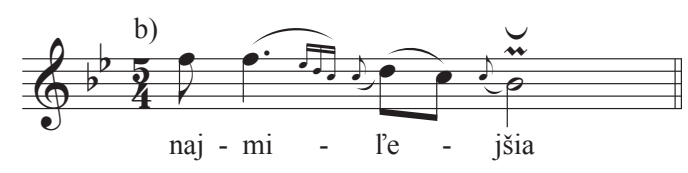

Typ IX

Najčastejšiu ozdobu, s ktorou sme sa stretli v Starej Pazove, predstavuje typ IX. Ide o binomickú ozdobu krátkeho trvania, ktorá má striedavý charakter. Spravidla poklesne vel'kou alebo malou sekundou na susedný tón a potom sa vráti k svojmu východiskovému tónu. Je umiestnená za notami rôzneho trvania - zaznamenali sme ju za polovou rytmickou hodnotou s bodkou, za polovou, štvrtovou rytmickou hodnotou s bodkou, za štvrtovou, za osminovou s bodkou alebo za osminovou rytmickou hodnotou. Aj ked’ sme ozdobu zaznamenávali ako dve šestnástiny, väčšinou druhá z nich trvá o niečo dlhšie. DÍžka tejto ozdoby záleží aj od samotného charakteru piesne. Vyskytuje sa v piesňach rozličného charakteru a tempa. Najčastejšie sa objavuje na neprízvučných dobách v takte, často na poslednej slabike slova. Neraz sa preto objaví v závere určitého verša, frázy alebo celej strofy piesne.

\section{Ukážka 17:}

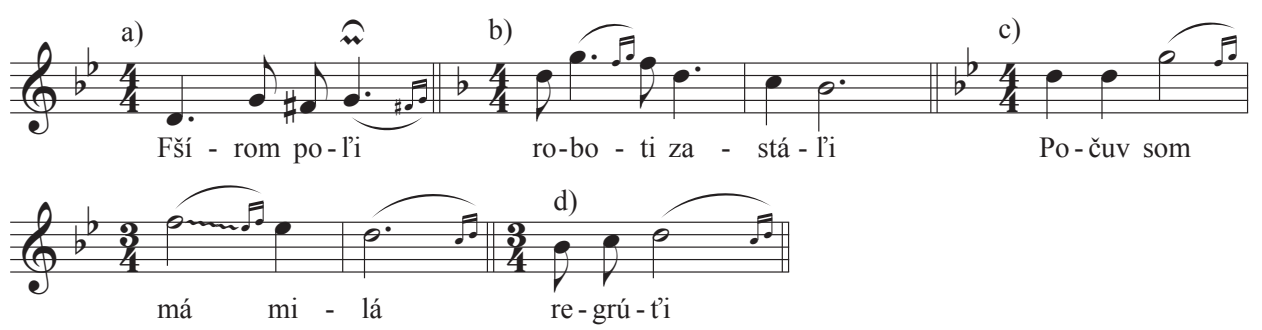

Typ X

Menej často sa stretávame s binomickou ozdobou, ktorá je melodickou obmenou predchádzajúcej ozdoby. Má takisto striedavý charakter, avšak z východiskového tónu vybočí na vrchnú vel'kú alebo malú sekundu a potom sa vráti spät. Najčastejšie sa viaže k štvrtovej note, pričom sa môže objavit’ na prízvučnej rovnako ako na neprízvučnej dobe v takte. Zaznamenali sme ju v piesňach rôzneho charakteru, avšak najčastejšie v piesňach rýchlejšieho tempa.

Ukážka 18:

a)

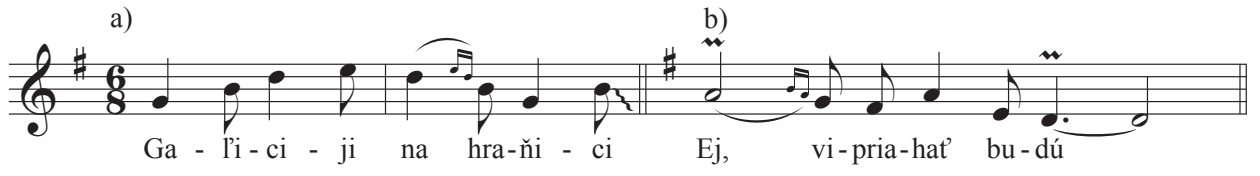




\section{Ozdoby v podobe skupiniek}

\section{Typ XI}

Ojedinele sa môžeme stretnút s ozdobou, ktorá pripomína obal. Zaznamenali sme ju najmä v rámci novej piesňovej kultúry. Podstata ozdoby tohto typu spočíva v obalení hlavnej doby susednými tónmi zvrchu a zospodu.

\section{Ukážka 19:}

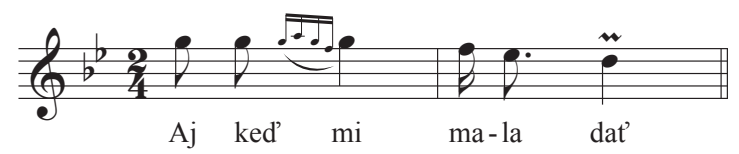

\section{Typ XII}

K tomuto typu sme zaradili rôzne ozdobné skupinky. Skupinka v tomto piesňovom repertoári predstavuje súbor zväčša štyroch a viacerých nôt na jednu slabiku. Najčastejšie sa vyskytujú za samostatným tónom, len ojedinele sa môžu objavit pred ním. V súčasnosti sa skupinky v pazovskom speve tak často nevyskytujú. Zaznamenali sme ich predovšetkým v piesňach štýlovej medzivrstvy modálneho charakteru pri modálnych a pri pentatonických piesňach. Pritom ich uplatňovali len niektorí speváci.

\section{Ukážka 20:}

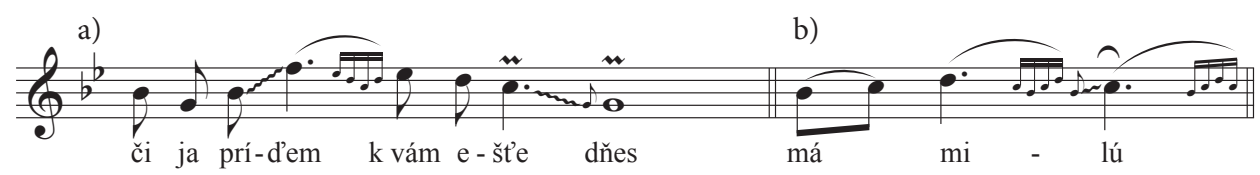

\section{Typ XIII}

Posledná ozdoba pripomína krátky trilok. Je mimoriadne vzácna. Zaznamenali sme ju len v podaní dvoch interpretov: Jána Pecníka (1930 - 2020) a Vladimíra Žolnaja (nar. 1964). Obaja speváci vo všeobecnosti aplikovali v speve množstvo ozdôb. Ozdoba sa môže vyskytnút pred samostatným tónom alebo za ním, pričom častejší je druhý prípad.

\section{Ukážka 21:}

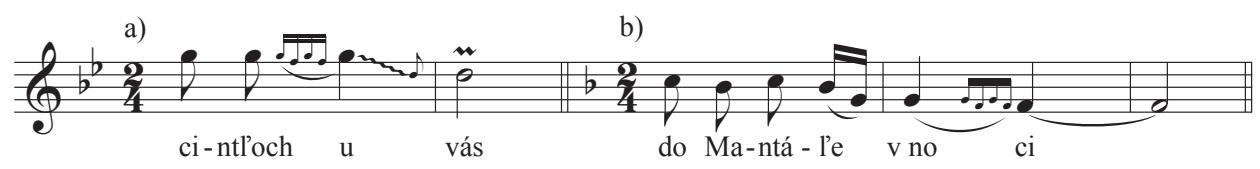

Uvedené typy predstavujú súhrn ozdôb, ktoré sme zaznamenali v pazovských slovenských piesňach. Okrem nich sa pravdepodobne možno stretnút s niektorými dalǎśimi ozdobami, avšak domnievame sa, že tie sa vyskytujú len výnimočne.

Na tomto mieste sa nám žiada upozornit čitatela aj na existenciu melizmatického spevu v tejto lokalite. Pod pojmom melizma chápeme skupinu nôt (pritom nemusí íst 
len o ozdoby), ktoré pripadajú na jednu slabiku textu. ${ }^{104} \mathrm{Ak}$ sa v rámci piesne takýto spôsob spevu opakuje, môžeme hovorit’ o melizmatickom speve. ${ }^{105}$ Okrem ozdobného spevu sme sa v Starej Pazove stretli (aj ked'v ovel'a menšej miere) aj s melizmatickým spevom. V rámci takéhoto spevu na jednu slabiku pripadli nielen ozdoby, ale aj noty rôzneho rytmického trvania, ktoré boli metricky členitelné. S melizmatickým spevom sa môžeme stretnút prevažne v štýlovej medzivrstve modálneho charakteru pri pentatonických a modálnych piesňach. Ukážkou melizmatického spevu v Starej Pazove je pentatonická pieseň Teraz som si počau (Príklad 37), ktorá okrem množstva rozličných ozdôb obsahuje aj d’alšie tóny pripadajúce na jednu slabiku. Ukážku melizmatického spevu nachádzame aj v lúbostnej piesni L'etí siví sokol (Príklad 49), ktorá na rozdiel od predchádzajúcej ukážky neobsahuje ozdoby. Avšak aj tu na jednu slabiku textu pripadajú viaceré noty v takte vo všetkých veršoch piesne. Záznam patrí $\mathrm{k}$ novým harmonickým piesňam. $\mathrm{S}$ takýmito piesňami sa $\mathrm{v}$ súčasnosti stretávame len zriedka.

Z celkového počtu skúmaných piesní, ktoré $\mathrm{v}$ súčasnosti tvorí 314 záznamov, 200 z nich obsahovalo ozdoby, čo predstavuje $64 \%$ piesňového materiálu. Východiskový skúmaný piesňový súbor tak tvorilo 200 piesní. Z toho približne polovica $(50,5 \%)$ ozdobných piesní (101 záznamov) patrí k prechodnej štýlovej medzivrstve. Najnižší počet ozdôb sme zaznamenali v starej piesňovej kultúre (13 záznamov), v ktorej sa nachádza len $6,5 \%$ ozdobných piesní z celkového počtu. O niečo menej ako polovica ozdobných piesní (43\%) patrí k novej piesňovej kultúre.

Na záver tejto kapitoly prinášame tabulky, ktoré sumarizujú výskyt jednotlivých typov ozdôb v rámci rôznych hudobnoštýlových vrstiev. Tabulky sa vztahujú na hudobnoštýlové vrstvy starej piesňovej kultúry, na prechodnú štýlovú medzivrstvu a na novú piesňovú kultúru. Za zdobené sme považovali aj piesne, v ktorých sa objavila len jedna ozdoba, pričom sme brali do úvahy ich prítomnost̉ aj v rámci strofických variantov. Tabul'ky obsahujú tonalitu piesní (T.), počet zdobených piesní $\mathrm{z}$ celkového počtu piesní $\mathrm{v}$ určitej hudobnoštýlovej vrstve (počet z. p.), ktorý je následne znázornený $\mathrm{v}$ percentách. $\mathrm{V}$ tabulkách je vyznačený aj výskyt jednotlivých typov ozdôb. Malým krížikom (+), sú vyznačené ozdoby objavujúce sa zriedka alebo ojedinele. Znakom x sú vyznačené ozdoby s častejším výskytom. Prázdne polička znamenajú absenciu určitého typu ozdôb v jednotlivých hudobnoštýlových vrstvách.

104 Development of composition in Middle Ages. Heslo. In: Encyclopedia Britannica. Dostupné na internete: <https://www.britannica.com/art/musical-composition/Development-of-composition-in-the-Middle-Ages\#ref530081>

105 HOPPIN, Richard H.: Hudba stredoveku. Bratislava : Hudobné centrum, 2007, s. 86-88. 
Tabulka 1: Výskyt ozdôb v starej piesňovej kultúre

\begin{tabular}{|c|c|c|c|c|c|c|c|c|c|c|c|c|c|c|c|c|}
\hline \multicolumn{17}{|c|}{ Celkový počet piesní: 37 záznamov (100 \%) } \\
\hline \multicolumn{17}{|c|}{ Celkový počet zdobených piesní: 13 záznamov (35 \%) } \\
\hline $\mathrm{T}$. & $\begin{array}{c}\text { Počet } \\
\text { z.p. }\end{array}$ & $\begin{array}{l}\mathrm{V} \\
\%\end{array}$ & $\begin{array}{c}\text { Typ } \\
\text { I }\end{array}$ & $\begin{array}{l}\text { Typ } \\
\text { II }\end{array}$ & $\begin{array}{l}\text { Typ } \\
\text { III }\end{array}$ & $\begin{array}{l}\text { Typ } \\
\text { IV }\end{array}$ & Typ & $\begin{array}{l}\text { Typ } \\
\text { VI }\end{array}$ & $\begin{array}{l}\text { Typ } \\
\text { VII }\end{array}$ & $\begin{array}{l}\text { Typ } \\
\text { VIII }\end{array}$ & $\begin{array}{l}\text { Typ } \\
\text { IX }\end{array}$ & Typ & $\begin{array}{l}\text { Typ } \\
\text { XI }\end{array}$ & $\begin{array}{l}\text { Typ } \\
\text { XII }\end{array}$ & \begin{tabular}{l|} 
Typ \\
XIII
\end{tabular} & iné \\
\hline $1-3$ & $0 / 5$ & 0 & & & & & & & & & & & & & & \\
\hline $4,6 / 4$ & $0 / 1$ & 0 & & & & & & & & & & & & & & \\
\hline 5,55 & $3 / 13$ & 23 & + & & & + & & & + & & + & + & + & & & \\
\hline $5 / 3$ & $10 / 18$ & 56 & + & & & $\mathrm{x}$ & + & + & + & & + & & + & & & \\
\hline
\end{tabular}

Tabulka 2: Výskyt ozdôb v prechodnej štýlovej medzivrstve

\begin{tabular}{|c|c|c|c|c|c|c|c|c|c|c|c|c|c|c|c|c|}
\hline \multicolumn{17}{|c|}{ Celkový počet piesní: 117 záznamov (100 \%) } \\
\hline \multicolumn{17}{|c|}{ Celkový počet zdobených piesní: 101 záznamov (86 \%) } \\
\hline T. & $\begin{array}{l}\text { Počet } \\
\text { z. p. }\end{array}$ & $\begin{array}{l}\mathrm{V} \\
\%\end{array}$ & $\begin{array}{c}\text { Typ } \\
\text { I }\end{array}$ & $\begin{array}{c}\text { Typ } \\
\text { II }\end{array}$ & $\begin{array}{l}\text { Typ } \\
\text { III }\end{array}$ & $\begin{array}{l}\text { Typ } \\
\text { IV }\end{array}$ & $\begin{array}{l}\text { Typ } \\
\text { V }\end{array}$ & $\begin{array}{l}\text { Typ } \\
\text { VI }\end{array}$ & $\begin{array}{l}\text { Typ } \\
\text { VII }\end{array}$ & $\begin{array}{l}\text { Typ } \\
\text { VIII }\end{array}$ & $\begin{array}{l}\text { Typ } \\
\text { IX }\end{array}$ & $\begin{array}{c}\text { Typ } \\
\text { X }\end{array}$ & $\begin{array}{l}\text { Typ } \\
\text { XI }\end{array}$ & $\begin{array}{l}\text { Typ } \\
\text { XII }\end{array}$ & $\begin{array}{l}\text { Typ } \\
\text { XIII }\end{array}$ & iné \\
\hline $7^{\mathrm{M}}$ & $9 / 9$ & 100 & $\mathrm{x}$ & & & $\mathrm{x}$ & + & + & + & + & $\mathrm{x}$ & + & & $\mathrm{x}$ & & \\
\hline $7^{\mathrm{P}}$ & $80 / 93$ & 86 & $\mathrm{x}$ & + & + & $\mathrm{x}$ & + & $\mathrm{x}$ & $\mathrm{x}$ & $\mathrm{x}$ & $\mathrm{x}$ & $\mathrm{x}$ & + & $\mathrm{x}$ & + & + \\
\hline $7^{\mathrm{H}}$ & $12 / 15$ & 80 & + & & & $\mathrm{x}$ & + & + & $\mathrm{x}$ & & + & + & & + & & \\
\hline
\end{tabular}

Tabulka 3: Výskyt ozdôb v novej piesňovej kultúre

\begin{tabular}{|c|c|c|c|c|c|c|c|c|c|c|c|c|c|c|c|c|}
\hline \multicolumn{17}{|c|}{ Celkový počet piesní: 160 záznamov (100 \%) } \\
\hline \multicolumn{17}{|c|}{ Celkový počet zdobených piesní: 86 záznamov (55 \%) } \\
\hline $\mathrm{T}$. & $\begin{array}{l}\text { Počet } \\
\text { z. p. }\end{array}$ & $\begin{array}{l}\mathrm{V} \\
\%\end{array}$ & $\begin{array}{c}\text { Typ } \\
\text { I }\end{array}$ & $\begin{array}{c}\text { Typ } \\
\text { II }\end{array}$ & \begin{tabular}{|l|} 
Typ \\
III
\end{tabular} & $\begin{array}{l}\text { Typ } \\
\text { IV }\end{array}$ & Typ & $\begin{array}{c}\text { Typ } \\
\text { VI }\end{array}$ & $\begin{array}{l}\text { Typ } \\
\text { VII }\end{array}$ & $\begin{array}{c}\text { Typ } \\
\text { VIII }\end{array}$ & $\begin{array}{l}\text { Typ } \\
\text { IX }\end{array}$ & $\begin{array}{c}\text { Typ } \\
\text { X }\end{array}$ & $\begin{array}{l}\text { Typ } \\
\text { XI }\end{array}$ & $\begin{array}{l}\text { Typ } \\
\text { XII }\end{array}$ & $\begin{array}{l}\text { Typ } \\
\text { XIII }\end{array}$ & iné \\
\hline $8^{\mathrm{H} 1}$ & $24 / 44$ & 55 & $\mathrm{x}$ & & + & $\mathrm{x}$ & + & $\mathrm{x}$ & $\mathrm{x}$ & + & $\mathrm{x}$ & $\mathrm{x}$ & + & & + & + \\
\hline $8^{\mathrm{H} 2}$ & $47 / 98$ & 48 & $\mathrm{x}$ & + & & $\mathrm{x}$ & + & $\mathrm{x}$ & $\mathrm{x}$ & + & $\mathrm{x}$ & $\mathrm{x}$ & + & + & + & + \\
\hline $8^{\mathrm{Z}}$ & $15 / 18$ & 83 & + & & & $\mathrm{x}$ & + & + & $\mathrm{x}$ & & $\mathrm{x}$ & + & + & & & \\
\hline
\end{tabular}

Najmenej ozdôb sme zaznamenali v piesňach starej piesňovej kultúry. Z celkového počtu, ktorý tvorí 37 záznamov, len 13 piesní obsahovalo ozdoby, čo predstavuje o niečo viac ako jednu tretinu (35\%) piesní. Aj v týchto piesňach sa vyskytujú iba sporadicky. Ozdoby sme zaznamenali len pri piesňach pastiersko-valaskej kultúry. V piesňach s kvintovou kostrou sa objavili pri 23 \% záznamov (3 piesne z 13 piesní). Častejší výskyt ozdôb sme zaznamenali v piesňach s kvintakordálnou kostrou. V rámci nich ozdoby obsahovalo 57 \% piesní (10 piesní z 18). O nižšom zastúpení ozdôb svedčí aj nižšia prítomnost’ jednotlivých typov, z ktorých je tu zastúpená len polovica.

Najvyšší výskyt ozdôb sme zaznamenali pri piesňach z prechodnej štýlovej medzivrstvy. Z celkového počtu 117 piesní až 101 záznamov malo bohaté zdobenie, čo predstavuje 86 \% piesní. Ozdobnost' je tu mimoriadne bohatá vo všetkých skupinách nielen z hladiska percentuálneho zastúpenia piesní, ale aj z hl'adiska uplatnenia ozdobných typov. Kompletné zastúpenie ozdôb sme zaznamenali pri modálnych piesňach (9 záznamov). S o niečo nižším zastúpením ozdôb sme sa stretli pri pentatonických 
piesňach. Z počtu 93 záznamov ozdoby neobsahovalo len 13 záznamov, 86 \%áznamov ozdoby obsahovalo. Pri pentatonických piesňach sme evidovali zastúpenie všetkých ozdobných typov. Najčastejšie sa však objavili typy: I, IV, VI, VII, VIII, IX, X a XII. Najnižšie percentuálne zastúpenie ozdôb v rámci tejto štýlovej medzivrstvy obsahujú hypotonálne piesne, kde sa ozdoby objavili v rozsahu 80 \% piesní (12 z 15 záznamov).

Ozdoby v novej piesňovej kultúre sú zastúpené len v polovici piesní. Zo 160 záznamov ozdoby obsahovalo 86 záznamov, čo predstavuje približne 55 \% piesní z celkového počtu záznamov v novej piesňovej kultúre. Avšak v týchto piesňach sme zaznamenali pomerne pestrú škálu ozdobných typov, ktorá bola najbohatšia pri starších harmonických piesňach. V starších harmonických piesňach sa ozdoby vyskytli v 24 záznamoch zo 44 (56 \%), v nových harmonických piesňach v 47 záznamoch z 98 (48\%). Najvýraznejšie zastúpenie sme zaznamenali pri nových harmonických piesňach západoeurópskeho typu, kde sa ozdoby objavili až v 15 piesňach z 18 zápisov, čo predstavuje $80 \%$ piesní.

V nasledujúcej kapitole budeme sledovat charakter ozdobnosti pri jednotlivých piesňach, ako aj aplikáciu ozdôb v podaní jednotlivých spevákov a speváčok. Zároveň budeme sledovat', v akej miere je ozdobnost' v piesni podmienená interpretáciou speváka.

\section{Ozdobné štýly a aplikácia ozdôb v interpretácii jednotlivých spevákov}

Etnomuzikologička Katalin Paksa vo svojej štúdii Connection of Style and Dialect in the Ornamentation of Hungarian Folksongs hned' v úvode nastoluje ( $\mathrm{z}$ nášho pohladu vel’mi výstižne) klúčovú otázku k výskumu ornamentálneho spevu:

„The key question of research on ornamentation is to find out whether each style and region has its own indigenous manner of ornamentation, or whether ornamentation is an independent historical formation, or maybe just the result of individual invention." 106

[„ Klúčovou otázkou pri výskume ornamentiky je zistit, či má každý štýl a región svoj vlastný, pôvodný spôsob ozdobnosti, alebo či je zdobenie nezávislým historickým útvarom, prípadne či je iba výsledkom individuálnej invencie (zručnosti, schopnosti)."]

V d’alšom priebehu štúdie K. Paksa venuje pozornost' práve prednesu niektorých zdobených ludových piesní. Na príklade dvoch mad’arských spevákov z odlišných regiónov (speváčky z okolia Zobora na území Slovenska a speváka z obce Kalotaszeg v Sedmohradsku na území Rumunska) autorka poukazuje na význam samotného prednesu a jeho vplyv na výslednú podobu piesne. Pri speváčke zo Zobora na vybraných piesňových príkladoch ilustruje odlišný spôsob zdobenia v rámci odlišných piesňových štýlov. Tento rozdiel je viditelný napriek skutočnosti, že obe piesne zaspievala tá istá speváčka. Naopak, pri spevákovi zo Sedmohradska sa rozdiely medzi jednotlivými melodickými štýlmi strácajú. $\mathrm{V}$ jeho prednese je v piesňach zastúpená

106 In: PAKSA, Ref. 62, s. 73. 
špecifická ozdobnost’ príznačná pre danú lokalitu, ktorá sa vyvinula z ornamentálnej hry na husliach približne v 17. - 18. storočí. ${ }^{107}$

Na otázky, ktoré vo svojej štúdii nastolila K. Paksa, v súčasnosti nemáme pri ozdobnom speve v slovenských piesňach zo Starej Pazovy spolahlivé odpovede. Otázka genézy tohto spevu predstavuje mimoriadne zložitú problematiku, ku ktorej sa v nasledujúcej kapitole tejto štúdie ešte vrátime. Na tomto mieste budeme venovat’ pozornost’ samotnému prednesu pazovských piesní a jeho súčasnej podobe.

$\mathrm{V}$ rámci tejto štúdie sme sa viackrát zmienili o spevákoch, ktorí aplikujú ozdoby mimoriadne často, a o spevákoch, ktorí ich aplikujú len niekedy. Snahu o zdobenie prejavili všetci speváci a speváčky zo všetkých vekových kategórií: z najstaršej, zo strednej aj z mladšej. Avšak medzi nimi vyniklo niekol'ko interpretov, ktorí v porovnaní s ostatnými aplikovali ozdoby mimoriadne často. Zaujímavá je skutočnost', že obzvlášt bohatá ozdobnost’ sa prejavila v interpretácii mužov z najstaršej a strednej generácie. Najbohatšie zdobenie sme zaznamenali u speváka z najstaršej vekovej kategórie Jána Pecníka (1930 - 2020) a u dvoch spevákov zo strednej generácie: Vladimíra Žolnaja (nar. 1964) a Pavla Leštana (1964 - 2015). Medzi ženami sme takéto mimoriadne bohaté zdobenie $\mathrm{v}$ rámci nášho výskumu nezaznamenali.

Ján Pecník využíval ozdoby prakticky vo všetkých piesňach. Z celkového počtu 75 piesní, ktoré sme od neho získali, bol ozdobný spev prítomný vo vyše 70 záznamoch. Na tomto mieste je potrebné zdôraznit’ skutočnost', že v interpretácii J. Pecníka sme zaznamenali nielen piesne patriace ku všetkým hudobnoštýlovým vrstvám v Starej Pazove. Pozoruhodné je aj rozsiahle tematické a žánrové spektrum piesní. V jeho podaní sme zaznamenali niektoré piesne kalendárneho cyklu, detský folklór (piesne, riekanky, hry), svadobné piesne, pohrebné plače, zbojnícke piesne, vojenské piesne, lúbostné piesne, sociálne piesne, vystahovalecké piesne, humoristické piesne i balady. S výnimkou niekol'kých detských hier J. Pecník aplikoval ozdobný spev vo všetkých ostatných piesňových kategóriách. Ukážky jeho ozdobenia môžeme sledovat’ vo vystahovaleckej piesni Ameriki roboti zastáli (Príklad 29), vo vojenskej piesni Teraz som si počau (Príklad 37), v lúbostnej piesni Ej, furmaňia idú (Príklad 39), v baladách Bou edom Štefam král'(Príklad 47) a Medzi dvoma brehami (Príklad 48), aj v pohrebných plačoch (Príklad 50).

Podobne bohaté zdobenie sme registrovali aj u speváka Pavla Leštana. Jeho piesňový korpus bol o niečo skromnejší. Z celkového počtu 44 piesní, ktoré sme od neho dokumentovali, sa ozdobný spev vyskytuje vo všetkých piesňach. Nižší výskyt ozdôb v jeho interpretácii sme zaznamenali len pri piesňach tempo giusto, ide však o úplne bežný jav vzhladom na tanečný charakter týchto piesní. ${ }^{108}$ Ukážky ozdobnosti v speve P. Leštana nachádzame napríklad v balade F šírom poli hruška stojí (Príklad 2), vo vojenskej piesni Ke som stáv na várte (Príklad 24), v regrútskej piesni Počkajte regrúti (Príklad 25), vo vojenskej piesni Pri mitrovskej bráňi (Príklad 34), ale aj v lúbostnej piesni Dám tii milá tri dukáti (Príklad 43) či v zbojníckej piesni Švárno djovča húske páslo (Príklad 44).

107 PAKSA, Ref. 62, s. 74.

108 PAKSA, Ref. 62, s. 74-76. 
Pomerne pestré zdobenie vo svojej interpretácii predviedol aj spevák Vladimír Žolnaj (nar. 1964). V jeho podaní sme zaznamenali 42 piesní, pričom ozdoby uplatnil prakticky vo všetkých piesňach. Ozdobnost', ktorú V. Žolnaj aplikoval pri speve, môžeme sledovat $\mathrm{v}$ piesňovej prílohe pri lúbostných piesňach Cesta hore, druhá dole (Príklad 26), Ked’ pójdem $z$ Pazova (Príklad 36), Pola nás, pola nás (Príklad 46) a v balade F šírom poli hruška stojí (Príklad 42).

Z uvedených príkladov je evidentné, že spomínaní traja speváci uplatňovali ozdoby $\mathrm{v}$ piesňach všade tam, kde to charakter piesne umožňoval, pričom išlo o značne rôznorodé piesne ako z tematického, tak i zo štrukturálneho hladiska. Spôsob, akým uplatňovali ozdoby, bol podobný. Namieste je preto otázka, či a do akej miery je pazovský spev výsledkom individuálnej invencie speváka, na čo poukazuje Katalin Paksa. Aplikovanie takéhoto ozdobného spevu si prirodzene vyžaduje určitú interpretačnú zručnost'. Domnievame sa však, že v pazovskom speve nejde len o takúto zručnost'.

Výskyt ozdôb a ich rozmanitost', ako sme mohli vidiet vyššie, boli najbohatšie predovšetkým v piesňach zo štýlovej medzivrstvy modálneho charakteru, najmä v modálnych a pentatonických piesňach. Môžeme sa preto domnievat', že ozdobnosṫ v týchto piesňach mohla byt̃ $\mathrm{v}$ minulosti ich neoddelitelnou súčastou, minimálne pri niektorých z nich. Taktiež možno predpokladat, že ozdobnost' k piesňam z ostatných hudobnoštýlových vrstiev prenikla práve z modálnych a pentatonických piesní. Pri analýze pentatonických piesní sa ukázalo, že ozdobnost̉ nie je vo všetkých pentatonických skupinách $\mathrm{z}$ hladiska charakteru rovnaká. ${ }^{109}$ Môžeme preto hovorit’ o rozličnom spôsobe ornamentácie, $\mathrm{z}$ ktorého nám vyplývajú určité ozdobné štýly. Z našich analýz a pozorovania sa nám javí, že v slovenských piesňach zo Starej Pazovy, v tzv. pazovskom speve, môžeme rozlišovat až tri ozdobné štýly. Domnievame sa, že v minulosti sa tieto štýly mohli viazat predovšetkým na pentatonické piesne. Na rozdielnost týchto štýlov preto poukážeme práve $\mathrm{v}$ rámci týchto piesní.

Prvý ozdobný štýl obsahuje ornamenty, ktoré sú zväčša zložené z jednej alebo nanajvýš dvoch tónových výšok. Tento ozdobný štýl sa viaže predovšetkým na piesne, ktoré sú metricky členitelné. Pritom tempo piesne nezohráva významnú úlohu. Zaznamenali sme ho v pomalších piesňach, rovnako ako aj v rýchlych. Na jednu slabiku $\mathrm{v}$ texte tak pripadne jedna hlavná nota s jednou alebo dvomi ozdobnými notami. Z hladiska funkcie sa takéto ozdoby javia ako obohatenie melodickej línie, na ktoré upozorňuje americký etnomuzikológ Byong Won Lee. ${ }^{110}$ Melodická línia tak nie je narušená ani v prípade, ak sú ozdoby pri speve úplne vynechané. Na takúto ozdobnost poukazuje aj K. Paksa. Na lepšie pochopenie uvádzame ukážku. Najprv prinášame príklad takejto ozdobnosti, ktorý približuje vo svojej publikácii K. Paksa, následne uvádzame ukážku tohto ozdobného štýlu na piesni z nášho vlastného terénneho výskumu.

109 LOMEN, Kristina: Pentatonika v tradičnom speve Slovákov v Starej Pazove (Srbsko): teória, typy, genéza. In: Musicologica Slovaca, roč. 11 (37), 2020, č. 2, s. 205-273.

110 BYONG-WEON, Ref. 93. 
Ukážka 22:

a) Prvý ozdobný štýl podla etnomuzikologičky K. Paksa ${ }^{111}$

Ex. 2

Giustu, $d=60-66$

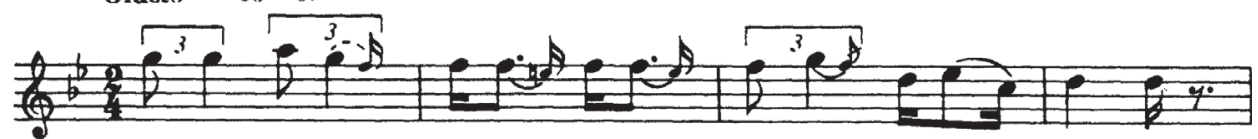

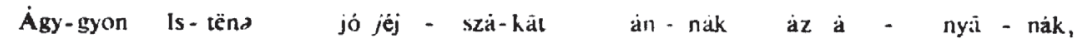

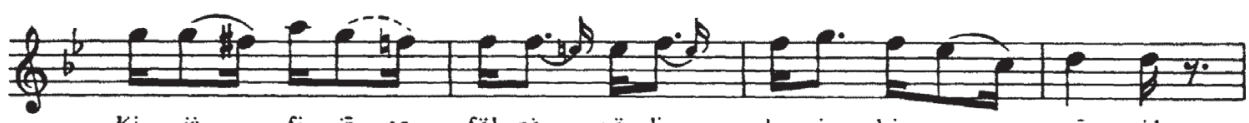

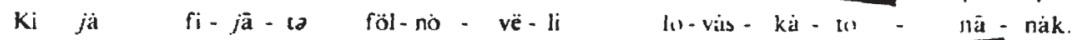

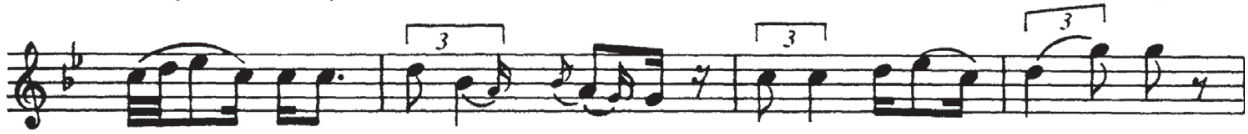

Ëj. èl-lëı. de gyöngy èl - lëı à ká - lw-ní é - lé,

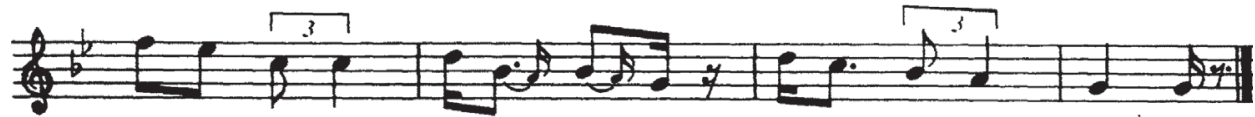

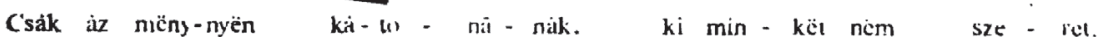

b) Prvý ozdobný štýl v piesňovom repertoári Starej Pazovy: lúbostná pieseň Ej, Zuzička, Zuzička
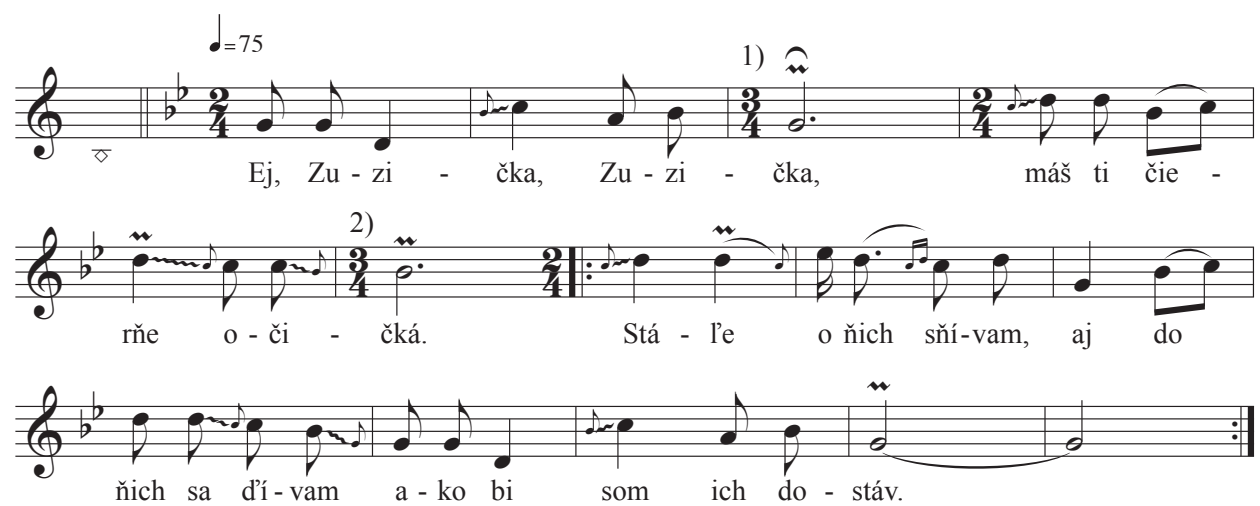

\section{$\begin{array}{ll}\text { 1) 2. sfa, 3. sfa } & \text { 2) 2. sfa, 3. sfa }\end{array}$}

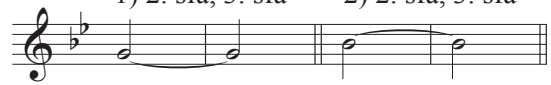


c) Prvý ozdobný štýl v piesňovom repertoári Starej Pazovy: svadobná pieseň Zeleňie sa paštrnáčik
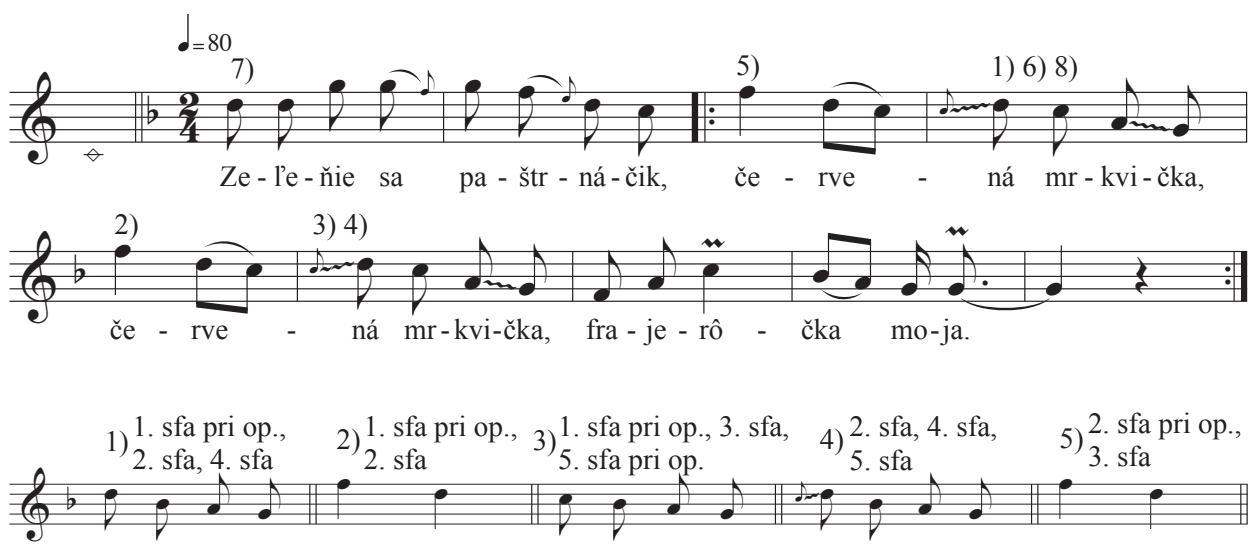

6) 3. sfa, 5. sfa pri op. 7) 4. sfa, 5. sfa

8) 5. sfa pred op.

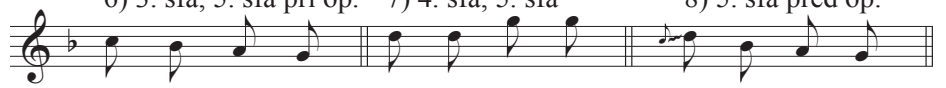

$\mathrm{Z}$ uvedených príkladov jasne môžeme vidiet jednak nepočetné ozdoby, jednak ozdoby, ktorých odstránením by hlavná melodická línia nebola narušená. Tento opísaný ozdobný štýl je v pazovských piesňach $\mathrm{z}$ nášho terénneho výskumu najčastejší. Najčastejšie sa vyskytuje aj v samotných pentatonických piesňach. Z celkového počtu 93 pentatonických piesní takýto ozdobný štýl obsahovalo až 50 záznamov, čo predstavuje 54 \% piesní. Ide o najjednoduchší spôsob zdobenia z hladiska samotného prednesu. Môžeme preto predpokladat, že je to aj jeden z dôvodov, vdaka ktorému je takýto ozdobný štýl v pazovských piesňach $\mathrm{v}$ súčasnosti najfrekventovanejší.

Druhý ozdobný štýl obsahuje podstatne širšie spektrum ozdôb. Ani v tomto prípade ich predvedenie nesúvisí $\mathrm{s}$ tempom piesní. Zaznamenali sme ho v pomalých, mierne rýchlych a rýchlych piesňach. Tieto ozdoby (aj ked' to $\mathrm{v}$ pazovskom speve nie je pravidlom) sa môžu $z$ hladiska dĺžky a hlasitosti vyrovnat hlavným tónom. K. Paksa hovorí, že takéto ozdoby nie sú oddelené od melodickej línie, ale majú rovnocenné postavenie s ňou. ${ }^{112} \mathrm{Na}$ ukážku uvádzame príklad, ktorý uviedla vo svojej štúdii K. Paksa na prezentáciu takéhoto ozdobného spevu, následne uvádzame druhý ozdobný štýl v pazovských piesňach. 
Ukážka 23:

a) Druhý ozdobný štýl $1^{113}$

Ex. 1

\section{Parlando $d=$ cca 88}
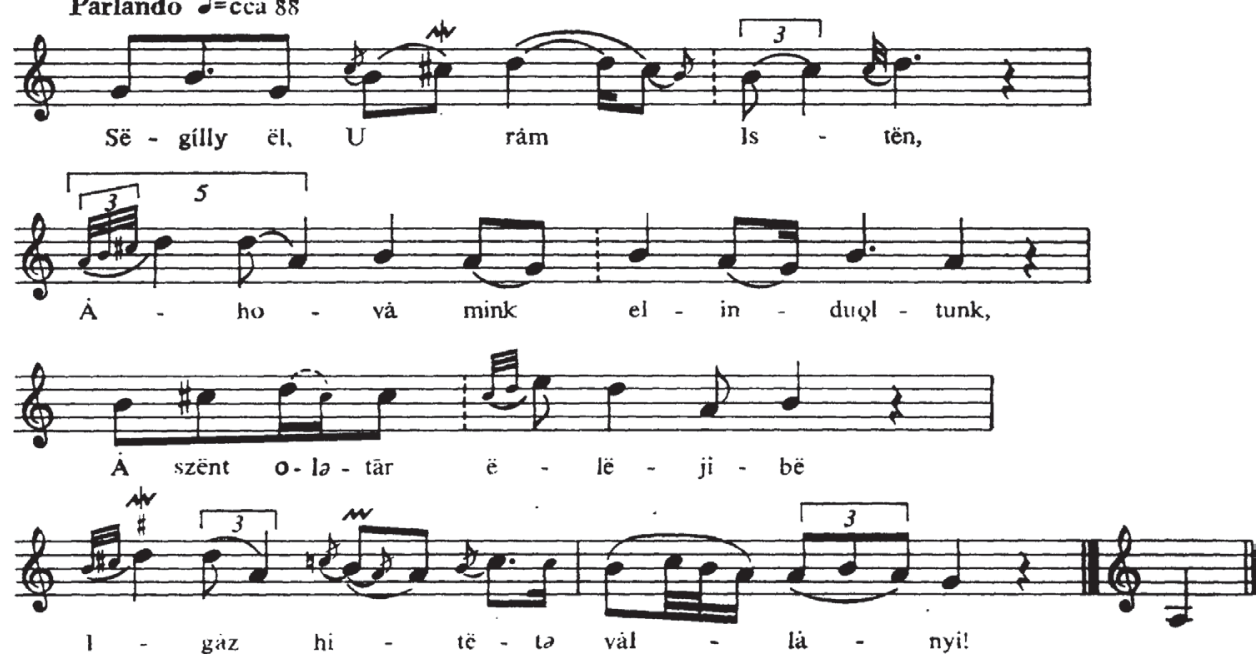

b) Druhý ozdobný štýl v piesňovom repertoári Starej Pazovy: žartovná pieseň Do potôčka voda tečie
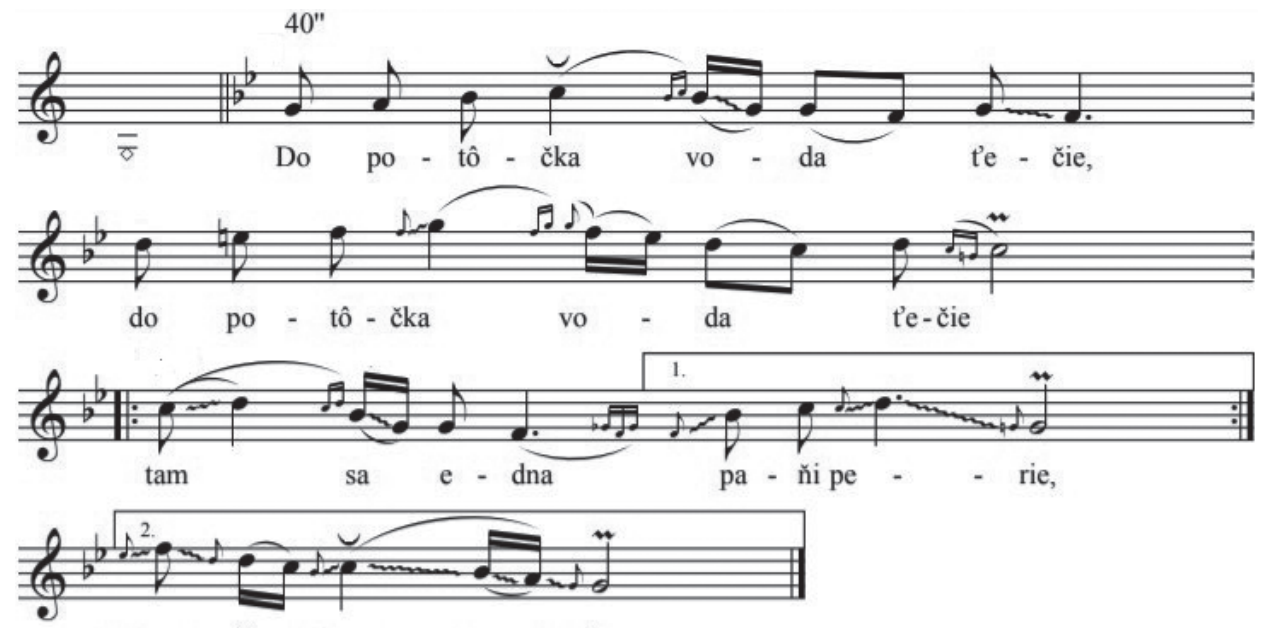

pa - ñi pe - - $\quad-$ rie.

V tomto štýle sú ozdoby pevnou súčastou melodickej línie. V praxi sme sa však stretli s ich vynechaním pri interpretácii piesní v podaní jednotlivých spevákov, u ktorých pretrváva takýto ozdobný štýl. Výsledkom bol značne odlišný variant piesne v po- 
rovnaní s variantom, kde bolo zdobenie zachované. Na lepšie pochopenie uvádzame príklad jednej a tej istej piesne v podaní odlišných spevákov. Variant v ukážke a), kde je ozdobnost’ zachovaná, spieval Pavel Leštan. V ukážke b) sa nachádza variant rovnakej piesne bez výraznejšieho uplatnenia ozdôb v podaní speváčky Zuzany Verešovej (nar. 1950). Počet piesní, v ktorých pretrváva druhý ozdobný štýl, je v súčasnosti o niečo nižší v porovnaní s prvým ozdobným štýlom, avšak stále nie je neobvyklým javom.

\section{Ukážka 24:}

a) Druhý ozdobný štýl v piesňovom repertoári Starej Pazovy, vojenská pieseň Ke som stáv na várte

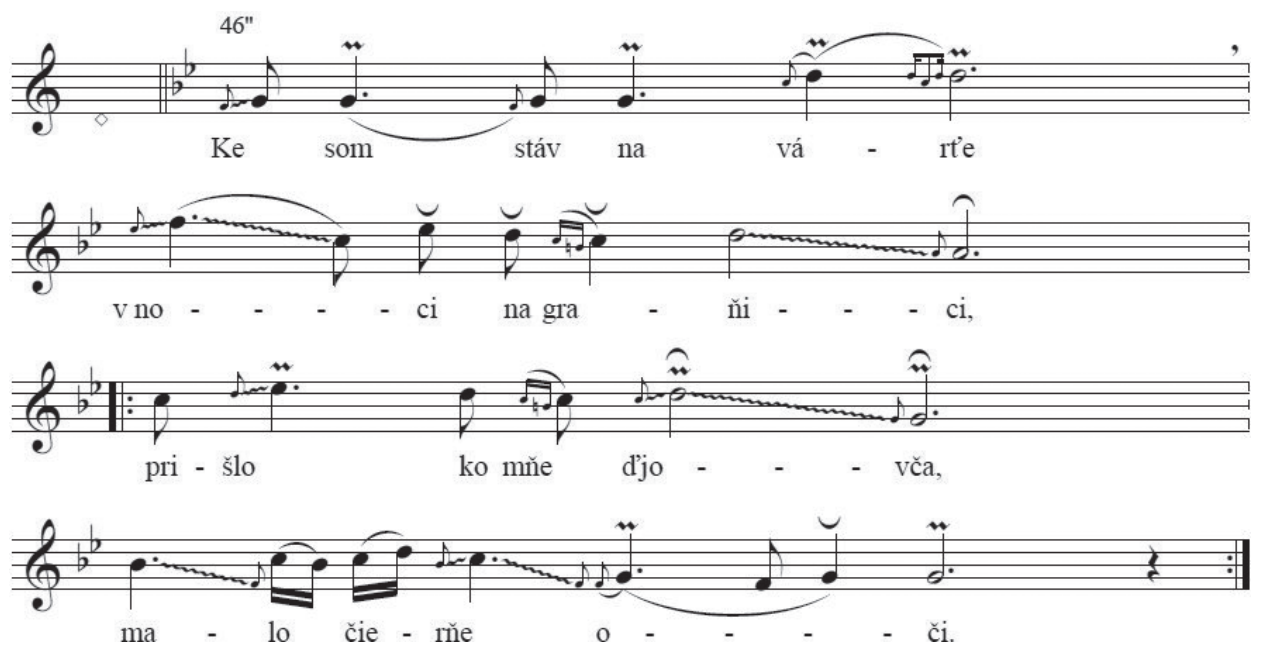

b) Vojenská pieseň Ke som stáv na várt’e bez aplikácie ornamentov

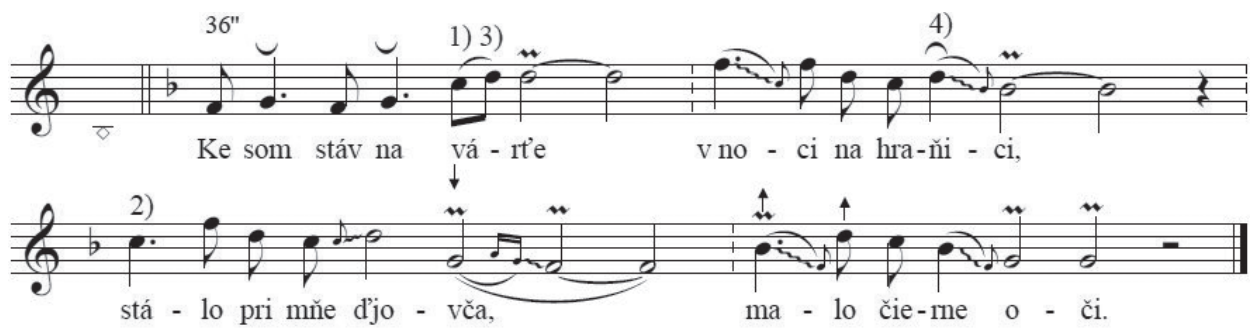

1) 2. sfa

2) 2. sfa

3) 3. sfa, 5. sfa

4) 4. sfa, $6 . \mathrm{sfa}$

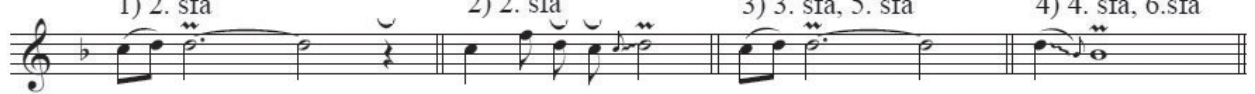

Tretí ozdobný štýl sa viaže len na piesne rubatového charakteru, ktoré majú ametrické nápevy. Jeho podstata spočíva v nemožnosti odlíšit melodickú líniu od ozdôb. Hranica medzi nimi v interpretácii je celkom zotretá. Počet piesní, v ktorých tento ozdobný štýl pretrváva, je v rámci nášho výskumu nízky (približne 17 záznamov). Domnievame sa však, že takýto spev mohol byt v minulosti ovela bohatší. Tento tretí 
ozdobný štýl v súčasnosti zaniká. Podla nášho názoru je jedným z dôvodov aj vysoká interpretačná náročnost', ktorá sa kladie na speváka. Na ukážku uvádzame jednu pieseň v podaní dvoch interpretov. Príklad lúbostnej piesne Tem pazovský kostolíček poukazuje na nemožnost vyspievania piesne bez ozdôb, a to aj napriek skutočnosti, že každý spevák uplatnil čiastočne odlišné ozdoby.

Ukážka 25:

a) Tretí ozdobný štýl v piesňovom repertoári Starej Pazovy: lúbostná pieseň Tem pazovskí kostolǐček, spev: Ján Pecník (1930 - 2020)
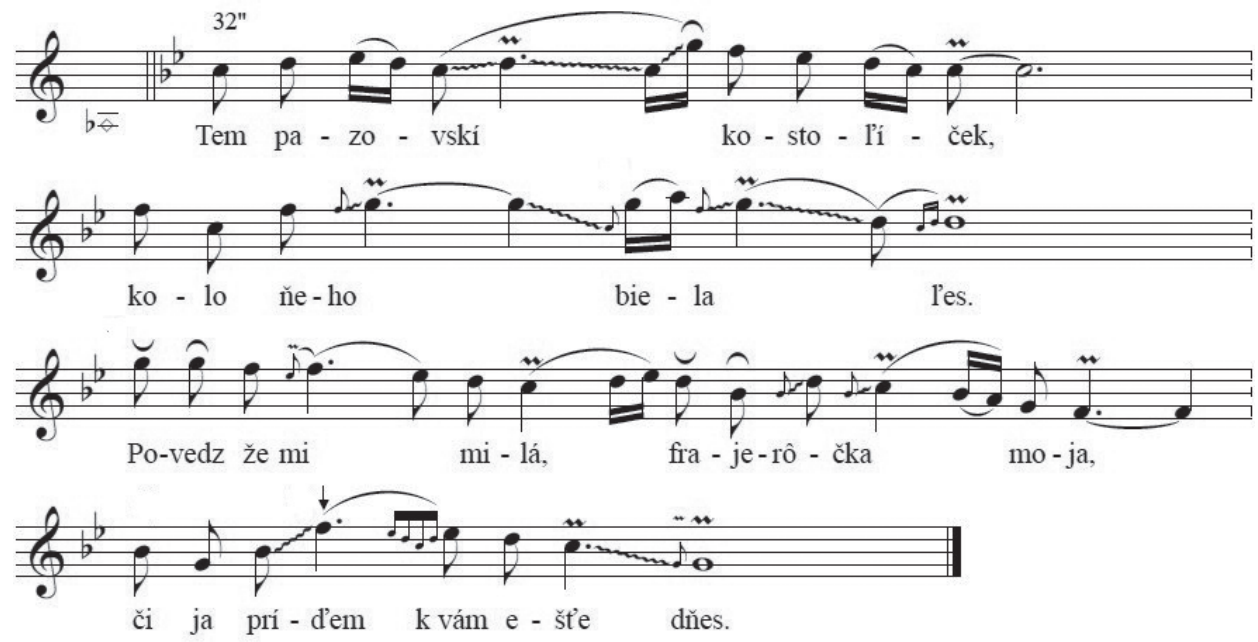

b) Tretí ozdobný štýl v piesňovom repertoári Starej Pazovy: lúbostná pieseň Tem pazovskí kostoliček, spev: Pavel Leštan (1964 - 2015)

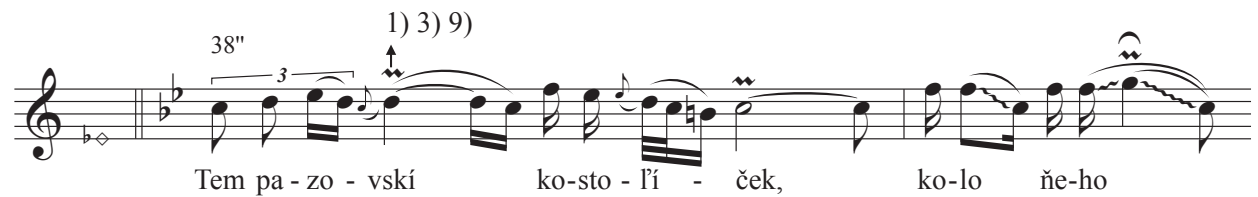
5)
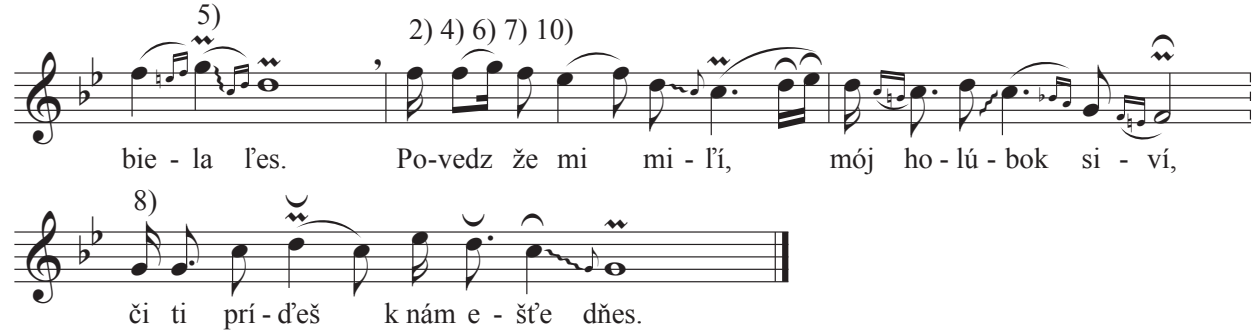


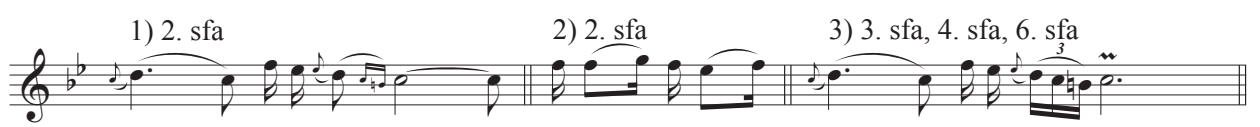

4) 3. sfa

5) 4. sfa, 5. sfa

6) 4. sfa

7) 5. sfa, 6. sfa

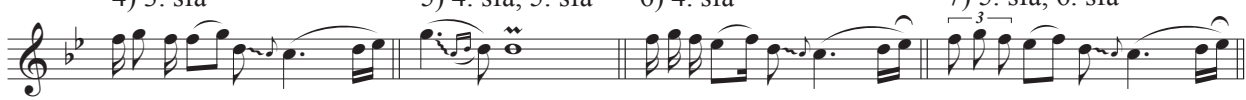

8) 6. sfa, 7. sfa

9) 7. sfa

10) 7. sfa

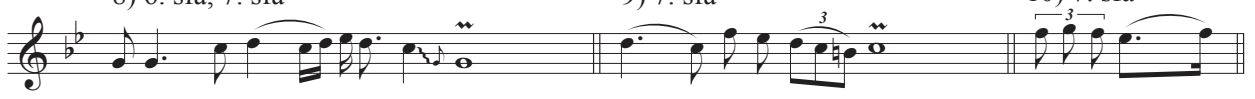

V dalších hudobnoštýlových vrstvách pretrváva najmä prvý ozdobný štýl. Nájdeme ho v starej piesňovej kultúre pri piesňach kvinttonálnych, $\mathrm{v}$ prechodnej štýlovej medzivrstve pri piesňach hypotonálnych a v nových harmonických piesňach. Druhý ozdobný štýl zasa nájdeme v starších harmonických piesňach. Najnáročnejší ozdobný štýl sme zaznamenali pri pentatonických a pri modálnych piesňach. $Z$ nášho výskumu vyplýva, že $\mathrm{v}$ súčasnosti je tento štýl zastúpený len $\mathrm{v}$ malom počte piesní. Je vysoko pravdepodobné, že ozdobnost' k dalším hudobnoštýlovým vrstvám prenikla práve z pentatonických piesní, prípadne z modálnych piesní. O ovplyvňovaní nových piesní staršími prvkami vo vztahu $\mathrm{k}$ zdobeniu hovorí aj K. Paksa. Avšak tento trend mohol byt prítomný len $\mathrm{v}$ izolovaných lokalitách a spoločnostiach, $\mathrm{v}$ ktorých pretrvával tradičný spôsob predvedenia piesňového repertoáru. ${ }^{114}$ Stará Pazova rozhodne patrila k takýmto lokalitám.

Z nášho výskumu vyplýva, že najzastúpenejší ozdobný štýl, ktorý dnes v Starej Pazove počut, je prvý štýl, druhý sa vyskytuje o niečo menej. Tretí ozdobný štýl sme dokumentovali zväčša $\mathrm{v}$ piesňach, ktoré Pazovčania ešte poznajú, ale $\mathrm{v}$ súčasnosti už často nespievajú. Domnievame sa, že takéto zastúpenie je späté s náročnostou samotného predvedenia ozdobných štýlov, pričom práve prvý z nich nekladie vysoké interpretačné nároky na speváka. Mladá generácia $\mathrm{v}$ súčasnosti nie je natolko spätá s tradičnými piesňami, ako to bolo v minulosti a ako to dnes dokladá najstaršia, ale aj stredná generácia. Náročnejšie ozdobné štýly tak v súčasnosti zanikajú. Vytrácajú sa aj niektoré piesne, v ktorých takýto spev tvorí ich integrálnu súčast'.

\section{Ku genéze ozdobného spevu v Starej Pazove}

Súčastou výskumu ozdobného spevu v Starej Pazove je prirodzene aj otázka o jeho pôvode. Táto otázka dlhodobo „prenasleduje“ nielen bádatelov, ale aj samotných Pazovčanov, ktorých pohlad na tento prednesový ozdobný štýl zohráva tiež dôležitú rolu. Často sa totiž možno stretnút s názorom, najmä medzi vojvodinskými Slovákmi z iných lokalít, že bohatý ozdobný spev alebo niektoré jeho prvky slovenskí Pazovčania prebrali od srbského etnika v tejto lokalite. Uvedený názor väčšina Slovákov v Starej Pazove nepripúšta. V súčasnosti nemáme postačujúce informácie, pomocou ktorých by sme sa mohli jednoznačne vyjadrit ku genéze ozdobného spevu v tejto lokalite. Na-

114 PAKSA, Ref. 62, s. 75. 
priek tomu však môžeme naznačit’ niektoré smery, ktorými by sa výskum v súvislosti s touto problematikou mohol v budúcnosti uberat'.

V súčasnosti existuje niekol'ko hypotéz týkajúcich sa genézy ozdobného spevu v pazovských slovenských tradičných piesňach.

Prvú hypotézu (najlogickejšiu a najjednoduchšiu) sme načrtli už vyššie - pazovskí Slováci bohatú ozdobnost’ mohli prevziat’ z tradičného spevu srbského etnika žijúceho v tej istej lokalite, prípadne v jej okolí. Problematike ozdobného spevu sa čiastočne venovali etnomuzikológovia L. Leng a M. Kmet', ktorí sa však k uvedenej hypotéze neprikláňali. M. Kmet’ osobitný ráz slovenskej l’udovej piesne pripisuje izolovanému prostrediu - od obyvatelov srbského aj slovenského etnika z iných slovenských lokalít Vojvodiny. ${ }^{115}$ Oddelenie slovenského obyvatel'stva v Starej Pazove od srbského etnika v tejto lokalite uvádza aj historik Karol Lilge. ${ }^{116} \mathrm{O}$ tejto izolovanosti ešte v nedávnej minulosti rozprávali aj samotní Pazovčania v rámci nášho vlastného terénneho výskumu. Pri požiadavke zaspievat tradičné srbské piesne mala väčšina informátorov problém na niektorú si spomenút. Väčšinou zazneli len komponované srbské piesne od súčasných populárnych autorov, ktoré zaspievali speváci strednej a mladšej generácie. Kmet’ hovorí, že okrem výraznej izolovanosti túto hypotézu nepripúšta ani samotná hudobnoštrukturálna analýza slovenských pazovských tradičných piesní. ${ }^{117}$

Terénny výskum u srbského etnika vo Vojvodine (v regióne Banát) uskutočnil aj B. Bartók. ${ }^{18} \mathrm{Na}$ základe vlastných analýz a komparácie piesňového materiálu odlišných etník Bartók dospel k poznaniu, že tzv. sedliacka hudba južných Slovanov nemá žiadnu podobnost̉ so starými mad’arskými parlandovo-rubatovými pentatonickými nápevmi. ${ }^{119}$ Túto podobnost' sme, naopak, zistili v pazovskom piesňovom repertoári. ${ }^{120}$ Vychádzajúc $\mathrm{z}$ existujúcich štúdií v súvislosti s tradičnými piesňami v Srbsku sa ukázalo, že väčšina hudobnoštrukturálnych prvkov sa v porovnaní so slovenskými piesňami v Starej Pazove líši. Odlišná je napríklad tonalita a finálne tóny piesní. V srbských ludových piesňach sa finálny tón nachádza najčastejšie na druhom tóne (alebo stupni), pričom bohatá ozdobnost' sa spája práve s týmito piesňami. ${ }^{121} \mathrm{~S}$ takýmto ukončením sme sa v pazovských piesňach nestretli. Odlišná je aj slabičná stavba verša (v srbských tradičných piesňach je najčastejšia desat’slabičná stavba verša) či hudobná forma, ale aj metrum. ${ }^{122}$ Zároveň repetičný princíp jednotlivých veršov, príznačný pre

115 LOMENOVÁ, Ref. 2.

116 LILGE, Ref. 6, s. 9-13

117 KMEŤ, Martin: Vplyv ludových hudobných nástrojov na vývin pazovského spievania. In: TURČAN, Ján (ed.): Stará Pazova 1770 - 1970. Zborník štúdií a článkov. Nový Sad : Obzor, 1971, s. 353.

118 SUCHOFF, Benjamin: Bartók and Serbo-Croatian Folk Music. In: The Musical Quarterly, roč. 58, 1972, č. 4, s. 557-571. RADINOVIĆ, Sanja - SZÜCS, Aranka - HELAJZEN, Esther: Béla Bartók and the Development of the Formal Analysis of Serbian Vocal Folk Melodies. In: Studia Musicologica, roč. 48, 2007, č. 1/2, s. 183-200.

119 SUCHOFF, Ref. 118, s. 561-562.

120 LOMEN, Ref. 109.

121 ŽGANEC, Vinko: The Tonal and Modal Structure of Yugoslav Folk Music. In: Journal of the International Folk Music Council, roč. 10, 1958, č. 1, s. 18-21.

122 PETROVIĆ, Radmila: Some Aspects of Formal Expression in Serbian Folk. In: Yearbook of the International Folk Music Council, roč. 2, 1970, s. 63-76. 
srbské ludové piesne, v pazovskom slovenskom speve úplne absentuje. ${ }^{123} \mathrm{Z}$ uvedeného vyplýva, že Slováci v Starej Pazove mohli prebrat naozaj len ozdobný spev, ak vôbec. Ozdobnost v ludových piesňach srbského etnika predstavuje samostatnú problematiku, ktorú by bolo potrebné bližšie preskúmat. ${ }^{124}$

Na základe uvedených skutočností sa nám táto hypotéza javí ako málo pravdepodobná, avšak považujeme za nevyhnutné zohladnit ju pri výskume ozdobného spevu. Uvedenú hypotézu by v súčasnosti bolo možné preskúmat pomocou terénneho výskumu - dokumentáciou piesňového materiálu od srbského etnika žijúceho v tejto lokalite. V prípade, že ozdoby budú identifikované ako súčast’ prednesu týchto piesní, by bolo potrebné podrobne preskúmat', aké typy ozdôb sa $\mathrm{v}$ týchto piesňach vyskytujú, alebo aký ozdobný štýl sa v srbských piesňach objavuje, či pripomína niektorý z ozdobných štýlov, na ktoré sme poukázali v tejto štúdii a v akej miere.

$\mathrm{K}$ ozdobnosti $\mathrm{v}$ tradičnom speve $\mathrm{z}$ danej lokality sa vyjadril aj L. Leng. Pre zaujímavost uvedieme jeho výrok celý, kedže ide o jeden z mála názorov na ozdobný spev v Starej Pazove v rámci jeho teoretickej reflexie:

„Ornamentálnu a melizmatickú ozdobnost staropazovských spevákov sme mali možnost porovnat so zápismi z dvoch zbierok ludových piesní. Jednou bola Plickova monografia Eva Studeničová spieva, ${ }^{125}$ druhou Srpske narodne melodije (predratna Srbija), zbierka piesní od Vladimira R. Georgevića. ${ }^{126}$ Georgevićove zápisy nie sú natolko precízne a Plickovým sa celkom nevyrovnajú. Zo spomínaného porovnania vyplynulo, že staropazovskej ozdobnosti je bližšia ornamentika Evy Studeničovej z Moravského Jána, okres Senica, ako ornamentika z uvedenej srbskej zbierky. Obalová ozdobnost', nadto okolo centra o diatonický stupeň nižšie a klesajúce diatonické behy - všetko vel’mi časté v srbskom materiáli - sa v prednese spevákov zo Starej Pazovy vyskytujú len zriedka. A naopak, bohaté uplatňovanie jedno- až dvojtónových prírazov a odrazov, čisté glissandové spojovanie dvoch susedných tónov a nadovšetko melizmatické vibráto, všetko velmi časté v staropazovských piesňach, v záznamoch srbských piesní nachádzame v niekolkokrát menšom zastúpení. Sme však daleko aj od tvrdenia, že by si boli staropazovská a stará moravskojánska vokálna ozdobnost' vel’mi blízke. To tiež nie. No sú si bližšie, ako spomínaný materiál publikovaný Georgevićom." ${ }^{127}$

Je otázne, prečo L. Leng siahol práve po uvedených piesňových zbierkach. Je pravdepodobné, že Leng porovnával vtedy dostupné piesňové zbierky, ktoré dokumentovali ozdobný spev. Uvedený Lengov výrok sa nám javí ako snaha nielen o vyvrátenie srbského pôvodu tejto ozdobnosti, ale aj o naznačenie jej slovenského pôvodu. Do-

123 PETROVIĆ, Ref. 122, s. 66-68.

124 Stručné zhrnutie k srbskej ludovej hudbe nachádzame In: RICE, Timothy - PORTER, James - GOERTZEN, Chris: The Garland Encyclopedia of World Music. Europe. Zv. 8. New York; London : Routledge, Taylor \& Francis Group, 2000, s. 940-956. Uvedený text poukazuje na komplexnost’ skúmania ludovej hudby srbského etnika, ktorú musíme mat' na zreteli aj pri skúmaní ozdôb. Jednou z nich je mimoriadne pestrá, multikultúrna spoločnost̉ obzvlášt v regióne Vojvodina, ktorá bola rôznorodá ešte v období Rakúsko-Uhorska.

125 PLICKA, Karol: Eva Studeničová spieva. Turčiansky Svätý Martin : Matica slovenská, 1928.

126 GEORGEVIĆ, Vladimir R.: Srpske narodne melodije. Beograd : Predratna Srbija, 1931.

127 LENG, Ref. 11, s. 350. 
mnievame sa však, že komparácia piesňového materiálu zameraná na skúmanie javu, akým je ozdobnost', by si vyžadovala prácu so zvukovým záznamom.

Citátom L. Lenga sa dostávame k druhej hypotéze, ktorá predpokladá, že slovenskí Pazovčania si ozdobný spev mohli priniest’ zo svojej pôvodnej vlasti. Najdôslednejšie zaznamenaný ozdobný spev medzi Slovákmi z rozmanitých regiónov nachádzame v zbierkach Karola Plicku. K. Plicka mimoriadnu ozdobnost' u slovenského obyvatelstva dokumentoval na Záhorí, v juhozápadnej časti Slovenska a v niektorých oblastiach východného Slovenska (Zemplín). ${ }^{128}$ Prezreli sme preto aj d’alšie zápisy piesní zo zbierky Slovenský spevník I, najmä tie, ktoré pochádzajú z obcí na Podpolaní a Horehroní. Zápisy niektorých z týchto piesní obsahujú ozdoby. Pripomínajú najjednoduchší ozdobný štýl, ktorý sme opísali pri pazovských piesňach. ${ }^{129} \mathrm{~V}$ súčasnosti nemáme k dispozícii zvukový záznam, ktorým by sme mohli overit zápisy uvedených piesní. Aj ked' je spol'ahlivost' týchto zápisov relatívna, prinajmenšom sa môžeme domnievat', že určitá ozdobnost’ tu prítomná bola.

Pre nás bolo zaujímavé zistenie, že ozdobnost’ K. Plicka dokumentoval aj vo vojvodinskom Kysáči (región Báčka, Srbsko) v piesni Ňinto po pou noci (č. 300) a Už je milá biela zora (č. 424). Ozdobný štýl v uvedených piesňach v značnej miere pripomínal pazovský spev (najmä prvý ozdobný štýl tejto lokality). Pieseň Ňinto po pou noci sme zaznamenali aj v rámci nášho terénneho výskumu v Starej Pazove.

\section{Ukážka 26:}
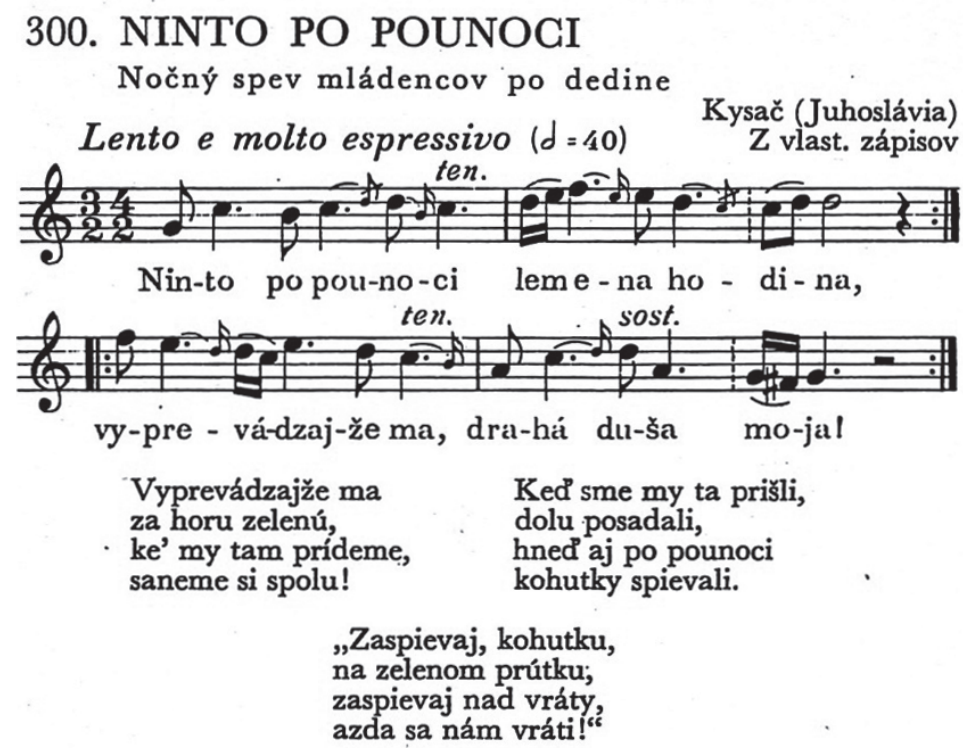

128 PLICKA, Ref. 1.

129 Plicka, Ref. 1, pieseň č. 105, č. 172, č. 266, č. 338, č. 393, č, 424, 439, č. 458, č. 471, 467. 
Ukážka 27:

\section{UŽ JE, MILÁ, BIELA ZORA \\ Spev mládencov $v$ noci po dedine}

Kysáč (Juhoslávia)

$Z$ vlast. zápisov

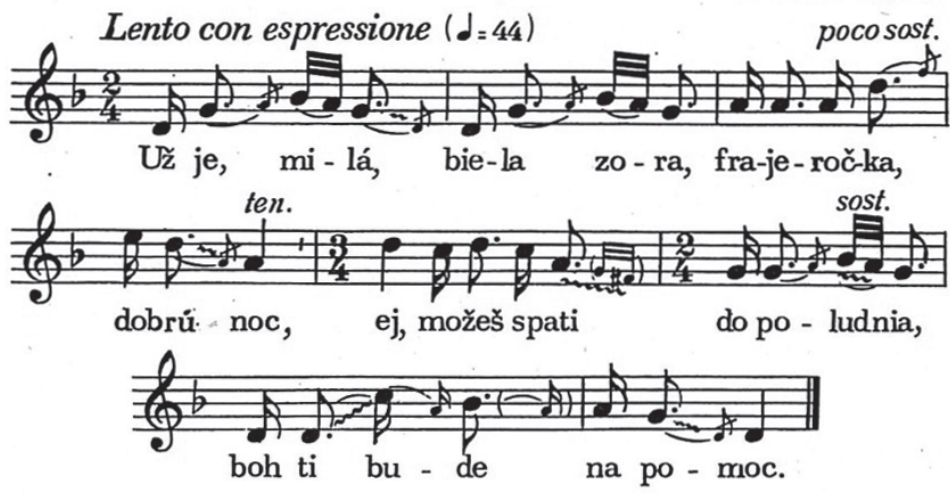

Sirom poli strom zelený, haluz bielim prekvitá, ej, moja milá smutná chodí, že ju nikto nepýtá.

Ked nepýtá, nak nepýtá, ja som $\mathrm{z}$ toho velmi rád, ej, na jeseň sa ženit budem, rád by ju ja k sebe ziat.

Uvedené ukážky vyvracajú doterajšiu mienku, že ozdobný spev sa viaže len na lokalitu Stará Pazova medzi Slovákmi vo Vojvodine. Z oboch ukážok vyplýva, že uvedená hypotéza prinajmenšom stojí za zváženie. Indície, ktoré naznačoval Leng, možno preto vziat do úvahy. Ozdobný spev v regiónoch, z ktorých prišli Pazovčania, mohol byt' v minulosti bohatší. Na preverenie tejto hypotézy by bolo potrebné podrobnejšie preskúmat piesňový repertoár obcí z Horehronia a Podpolania.

Tretia hypotéza predpokladá prienik určitých ozdobných prvkov do vokálnej tvorby $\mathrm{z}$ inštrumentálnej hudby. K tejto hypotéze sa prikláňal M. Kmet’, ktorý ju zároveň podrobnejšie rozpracoval. Tejto problematike sa podrobnejšie venoval vo svojej štúdii Vplyv inštrumentálnej hudby na vývin pazovského spievania. ${ }^{130} \mathrm{Kmet}$ poukazuje na silný vplyv inštrumentálnej hudby na melodiku a stavbu ludových nápevov. Prítomnost' hudobných nástrojov v Starej Pazove za posledných 200 rokov (od roku 1773) rozdeluje do troch období: ${ }^{31}$

1. Prevaha aerofonických (dychových) nástrojov (od roku 1770 približne do roku 1870), predovšetkým píštal.

2. Prevaha chordofonických (strunových) nástrojov (cca do roku 1920), medzi ktorými spomína citary, cimbaly a husle.

3. Od roku 1920 prevaha tahacích gombíkových harmoník, ktoré v tradičnej inštrumentálnej hudbe využívali najprv Srbi.

Kmet' vo svojej štúdii zastáva názor, že práve posledné dve obdobia, najmä však to po roku 1920, mohli mat' značný vplyv na vývin pazovského ozdobného spevu. V tejto

131 KMEŤ, Ref. 117, s. 357-360. 
štúdii vyslovil domnienku, že pôvod tohto ozdobného spevu môže spočívat' v inštrumentálnej hudbe. Skúma vplyv inštrumentálnej hudby na vývin špecifického pazovského spievania, pričom sa zameriava najmä na vplyvy, ktoré mohli pochádzat’ z hudobnej inštrumentálnej hry na t’ahacej gombíkovej harmonike. Na skutočnost’ prieniku ozdobných prvkov z inštrumentálnej tvorby poukazuje aj Katalin Paksa na príklade mad’arských ludových piesní u Mad’arov v Rumunsku, kde sa vyvinul osobitný prednesový štýl ozdobného spevu. ${ }^{132}$ Kmet’ uvádza, že k inštrumentálnej hudbe v Starej Pazove približne do roku 1870 žiadne údaje neexistujú. K uvedenej klasifikácii sa dopracoval „pomocou rekonštruujúcich prvkov““ ${ }^{133}$ Avšak prienik ozdobných prvkov z inštrumentálnej do piesňovej tradície Pazovčanov až v 20. storočí (čo vyplýva z Kmetovej štúdie) sa nám javí ako neskorý, a tak aj menej pravdepodobný. Podla našich domnienok je ozdobný spev v Starej Pazove starší. Ako pravdepodobnejší sa nám preto javí prienik ozdobných prvkov zo strunových nástrojov. Slovenskí odborníci a hudobníci skúmali ozdobné a variačné techniky predníkov na Slovensku. Z niektorých zápisov, ktoré udávajú, sa táto hypotéza môže javit’ ako pravdepodobná. ${ }^{134} \mathrm{~V}$ súčasnosti však ide len o hypotetické úvahy. Aj v tomto prípade by preto bolo potrebné vykonat podrobnejší výskum. Preskúmaním a akceptáciou hypotézy o prieniku ozdobných prvkov z inštrumentálnej hudby by sa ukázalo, či ozdobný spev Pazovčanov v skutočnosti mohol vzniknút v novom prostredí. Nastoluje sa však aj otázka, či Slováci z iných lokalít vo Vojvodine využívali podobné nástroje a ak áno, prečo sa prienik týchto prvkov potom neprejavil, prípadne nezachoval aj v iných slovenských lokalitách vo Vojvodine.

Posledná hypotéza vyplynula z našich vlastných výskumov. Je založená na predpoklade prieniku určitých hudobných prvkov, vrátane ozdobnosti, z tradičného spevu mad’arského etnika, pričom máme na mysli predovšetkým staršiu vrstvu mad’arských piesní. Náš najnovší výskum poukázal na bohaté zastúpenie pentatoniky v pazovskom piesňovom repertoári, podobne ako je to aj u mad’arského etnika. Pentatonike v pazovských piesňach sme sa podrobne venovali v štúdii Pentatonika $v$ tradičnom speve Slovákov v Starej Pazove (Srbsko): teória, typy, genéza. ${ }^{135} \mathrm{~K}$ pentatonickým piesňam sa viazala bohatá ozdobnost', na ktorú poukazoval začiatkom minulého storočia aj B. Bartók a Z. Kodály. Ozdobnost’ je predmetom skúmania aj v súčasnosti (K. Paksa). Z aktuálnych historiografických výskumov vyplýva, že čast’ Slovákov prišla do Starej Pazovy aj z Malého Kereša (Kiskőrös v dnešnom Mad’arsku). ${ }^{136}$ Pazovčania tak určitý čas pobudli na území Mad’arska, v dôsledku čoho mohla slovenská ludová pieseň v novom prostredí prevziat nové vplyvy a nadobudnút novú podobu. Zároveň existujú dokumenty, ktoré uvádzajú spolu s príchodom Slovákov aj príchod niekolkých desiatok madarských rodín do Starej Pazovy. ${ }^{137}$ Domnievame sa, že v dôsledku dlhodobejšieho

132 PAKSA, Ref. 62.

133 KMEŤ, Ref. 117, s. 355-356.

134 LENG, Ladislav - ELSCHEK, Oskár - CIBULKA, Stanislav - LETŇAN, Július - MÓŽI, Alexander - TONKOVIČ, Pavol - MAČÁK, Ivan - DEMO, Ondrej: Variačná technika predníkov v oblasti západného, stredného a východného Slovenska. Bratislava : Osvetový ústav, 1984.

135 LOMEN, Ref. 109.

136 MIKLOVIC, Jaroslav: Stará Pazova 1769 - 1794. Bratislava : Vydavatel'stvo ESA; Nadlak : Vydavatel'stvo Ivan Krasko, 2002.

137 LILGE, Ref. 6, s. 15, s. 35-41. 
spolunažívania slovenského a madarského etnika mohlo dôjst’ k preberaniu určitých hudobných prvkov.

Vzhladom na viaceré ozdobné štýly, s ktorými sme sa v Starej Pazove stretli, pripúštame možnost' kombinovanej genézy: niektoré ozdobné prvky si mohli Pazovčania priniest' zo svojej vlasti, niektoré mohli prevziat od iného etnika (srbského alebo madarského), niektoré sa mohli vyvinút z inštrumentálnej hudby. Všetky uvedené hypotézy považujeme za rovnocenné z hladiska potreby ich detailnejšieho preskúmania v budúcnosti.

\section{Záver}

V štúdii sme sa zamerali na skúmanie fenoménu ozdobného spevu v lokalite Stará Pazova, ktorému sa doposial nevenovala väčšia pozornost'. Priniesli sme prehlad o existujúcich zápisoch pazovských piesní, ktoré dokumentujú ozdobný spev. Ďalej sme sa zaoberali výskytom ozdôb $\mathrm{v}$ piesňach patriacich $\mathrm{k}$ rozmanitým hudobnoštýlovým vrstvám. Z celkového počtu 314 transkribovaných piesní až 200 obsahuje ozdoby.

Ukázalo sa, že ozdobný spev je zastúpený predovšetkým v piesňach z prechodnej štýlovej medzivrstvy: $\mathrm{v}$ modálnych piesňach, $\mathrm{v}$ pentatonických piesňach a $\mathrm{v}$ hypotonálnych piesňach. Bohatšia ozdobnost' sa vyskytuje aj v starších harmonických piesňach. Následne sme sa zaoberali otázkou transkripcie pazovských piesní, pričom sme opísali postup, ktorý sme uplatňovali pri našom vlastnom zápise piesní a ozdôb v Starej Pazove.

Rozsiahlejšia čast štúdie sa zaoberala opisom jednotlivých typov ozdôb, ktoré sme v Starej Pazove zaznamenali. Ich celkový počet tvorí 13 typov, ktoré sme rozdelili do troch podskupín: typy ozdôb, ktoré sa vyskytujú pred notou, typy ozdôb, ktoré sa vyskytujú za notou, a ozdoby v podobe skupiniek, ktoré sa môžu objavit pred notou, rovnako ako aj za notou. Po deskripcii ozdôb sme priniesli prehlad ich výskytu pri jednotlivých hudobnoštýlových vrstvách. Ďalej sme sa zaoberali ozdobnými štýlmi, ktoré sme zaznamenali v Starej Pazove. Náš výskum poukázal na tri rozdielne ozdobné štýly, ktoré sme determinovali na základe piesňového materiálu dokumentovaného $\mathrm{v}$ rámci našich vlastných terénnych výskumov. Prvý z nich je z hladiska prednesu najjednoduchší, druhý obsahuje početnejšie a o niečo komplikovanejšie ozdoby, v tretom z nich sú ozdoby neoddelitelnou súčastou melodickej línie.

$\mathrm{V}$ poslednej kapitole sme naznačili štyri možné hypotézy v súvislosti s genézou ozdobného spevu v lokalite Stará Pazova: prvá z nich naznačuje srbský pôvod, druhá slovenský, tretia pripúšta prienik ozdobných prvkov z inštrumentálnej hudby. Posledná hypotéza vychádza zo skutočnosti koexistencie slovenského a madarského etnika v rovnakej lokalite a pripúšta prebranie určitých hudobných prvkov vrátane ozdobnosti od madarského etnika. Žiadna z hypotéz nie je v súčasnosti dostatočne preskúmaná, každá z nich preto poukazuje na smery, ktorými sa môže výskum v súvislosti s touto problematikou $\mathrm{v}$ budúcnosti uberat.

Štúdia je súčastou grantového projektu VEGA č. 2/0145/18 „Systematika piesňových žánrov v tradičnej hudobnej kultúre“ (2018 - 2021), riešeného v Ústave hudobnej vedy SAV. 


\section{PRÍLOHA}

\section{Príklad 1}

a) Lúbostná pieseň, spev: neznámy, zber a zápis: Benjamín Kamenár, prvá polovica 20. storočia, Stará Pazova

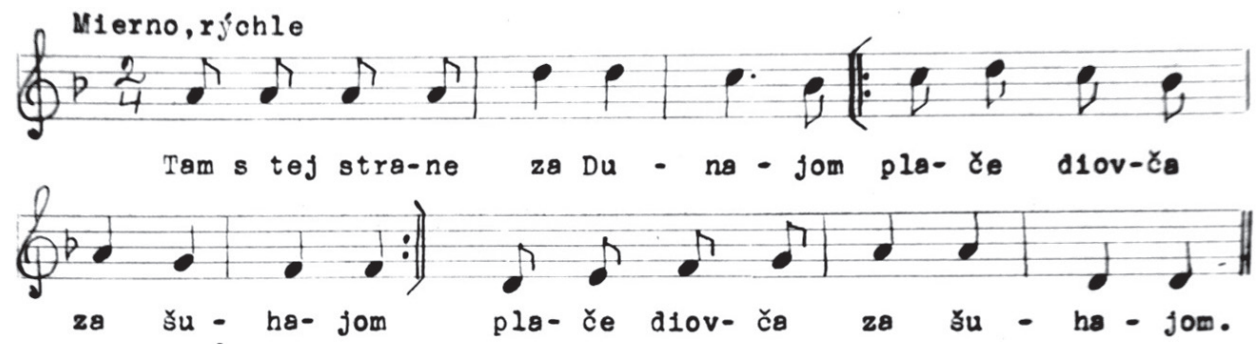

1. Tam s tej strane za Dunajom, /splače diovča za suhajoms/.

2. Ako by som neplakala, /a ke som ja s nim sadavalaj/.

3. Sadavala spievavala, / jeho lícka boskavala,/.

4. M1luj milá más aj koho, /inemilujes makar kohoi/.

5. Leprie t1 je miluvat1

/1ako zajtra banuvat1:/. 
b) Lúbostná pieseň, spev: Pavel Leštan (1964 - 2015), zápis: Kristina Lomen, apríl 2014, Stará Pazova
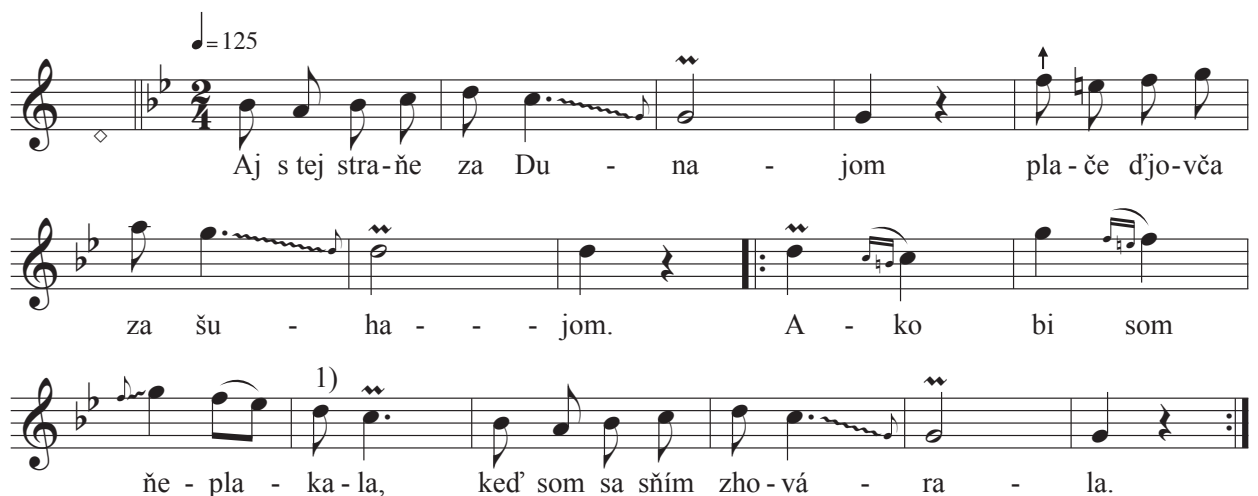

1) 3. sfa

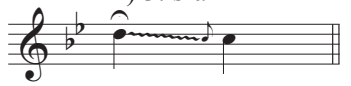

1. Aj s tej straňe za Dunajom

plače djovča za šuhajom.

/: Ako bi som ňeplakala,

ke som sa s ňím zhovárala. :/

2. Zhovárala, sedávala,

aj som sa s ńím miluvala.

/: Zhovárala, sedávala,

aj som sa s ňím miluvala. :/

3. Miluj, miluj kím máš koho,

ňemiluješ makar koho.

/: Miluješ ti djovča švárne,

čo má ono očká čierne. :/ 
Príklad 2

a) Vojenská pieseň, spev: neznámy, zber a zápis: Benjamín Kamenár, prvá polovica 20. storočia, Stará Pazova

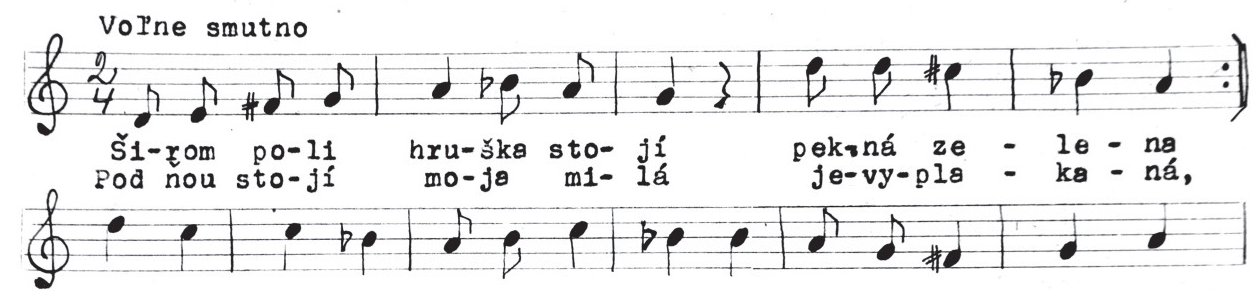

bie-lý ruč-nfkv ru-ce ma s nim si o-čka u - tie - ra

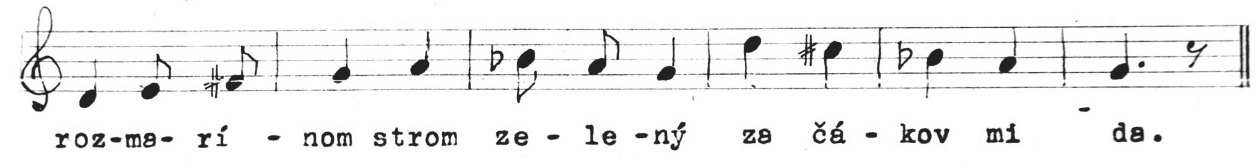

\begin{tabular}{l}
$\mathrm{C}$ \\
\hline \\
\hline
\end{tabular}

1. Širom pol1 hruskes stojí

pekná zelena

pod ňou stojí moja milá

je vyplakaná,

bielý ručnik v ruce ma

a nim s1 otka ut1era

rozmarinom strom zelený

29 čákov m1 da.

2. Ani som si sam nemislev,

že vojak budem,

že na mojom ja hlo plec1

pušku nosit budem,

a pri bvočku sabličku

plače otec a mamičkou,

že stratill svojho syna

v dvac1atom rvoðku. 
b) Lúbostná pieseň, spev: Pavel Leštan (1964 - 2015), zápis: Kristina Lomen, apríl 2014, Stará Pazova
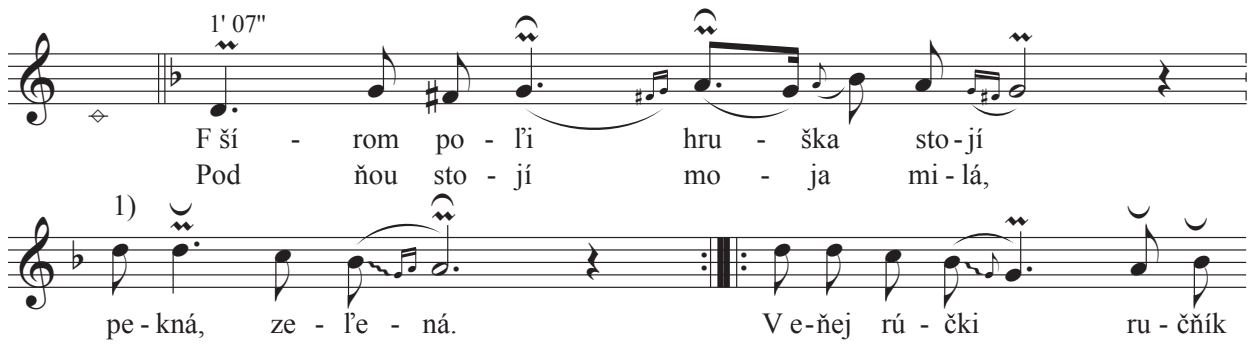

ňe - vi - pla - ka - ná.
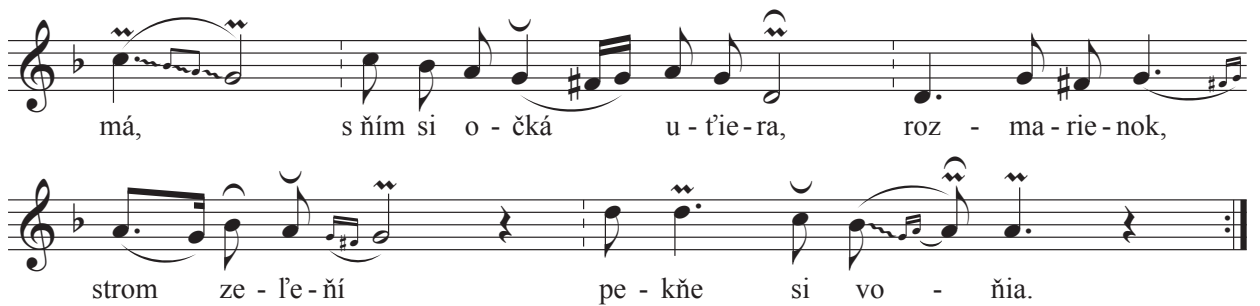

1) 1. sfa pri op.

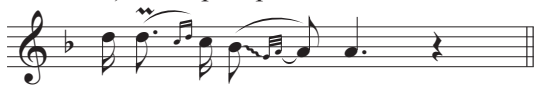

1. F šírom poli hruška stojí

pekná, zel’ená.

Pod ňou stojí moja milá, ňeviplakaná.

I: V eňej rúčki ručňík má,

s ňím si očká utiera,

rozmarjenok, strom zeleňí

pekňe si voňia. :/

2. Ňeved’eu som tejto noci,

že vojak bud’em,

že na svojom pleci pušku

nosievat' bud'em.

Aj na bôčku šablička,

plačú otec, mamička,

že stratili svojho sina

$\mathrm{v}$ dvaciatom rôčku.

Ňeplačú tak otec, mat’ ako plače frajerka,

že jej bud'e nocuvávat'

prázna postiel'ka. 
Príklad 3

a) Balada, spev: neznámy, zber a zápis: Benjamín Kamenár, prvá polovica 20. storočia, Stará Pazova

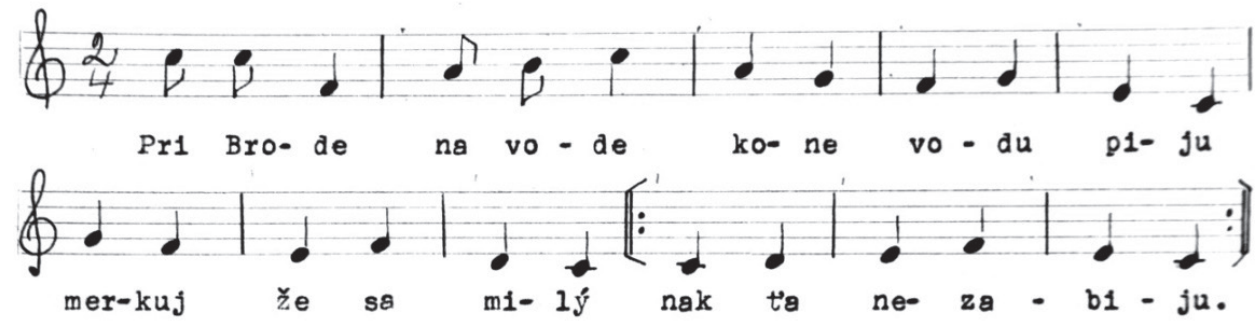

1. Pri Brode no vode

kone vodu piju

merkug že sa m1lý

/anak to nezabijus/.

2. Kone zrihotali

nohou dupotali

sko by Aničky

/ana známost dával1:/.

3. Anka nemeskala

rybárom bežalas

rybarí rybarí

chytajte tu rybu

mojmu srdou libu.
4. Prvý raz začıahli hodinke vytiahli druhý raz začiahl1 Janiks vytiahl1. Ach to je tá ryba mojmu srcu líba.

5. Anka nemeřkala t1รliarom beร̌ala:

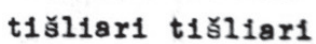
robte takú truhlu čo dva do nef rahnu.

5. Anka nemeక̌kala hrobárom bežalas hrobár1, hrobár1 kopte takú jamu to dva do nef rahnu. 
b) Balada, spev: Jaroslava Vršková Opavská (nar. 1985), zápis: Kristina Lomen, apríl 2014, Stará Pazova

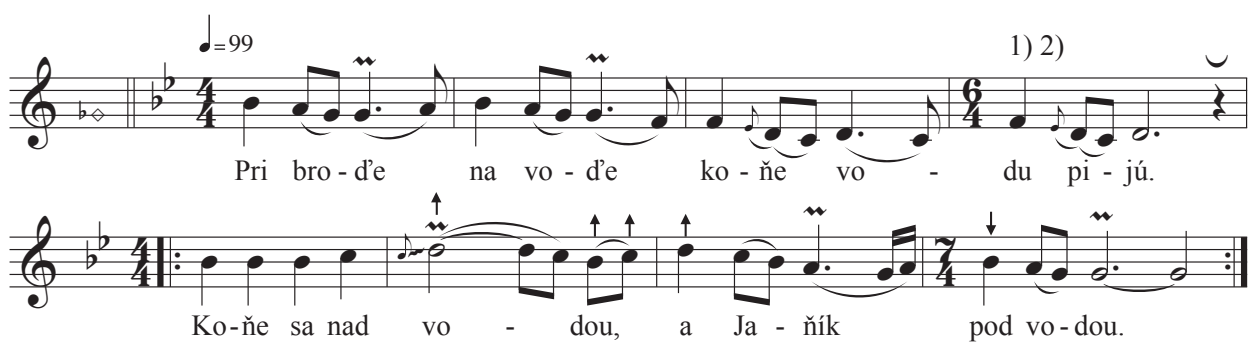

$\begin{array}{ll}\text { 1) 2. } \mathrm{sfa}, 4 . \mathrm{sfa}, 5 . \mathrm{sfa} & \text { 2) 3. sfa }\end{array}$

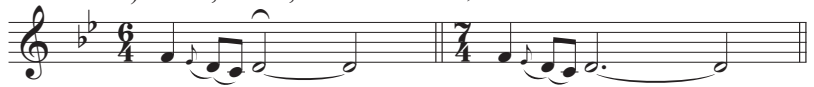

1. Pri brod'e na vod'e

koňe vodu pijú.

/: Koňe sa nad vodou,

a Jaňík pod vodou. :/

2. Koňe zrihotali,

akobi plakali,

/: akobi Aňički

na známost̉ dávalì. :/

3. Anka ňemeškala,

fišerom bežala.

Fišeri, fišeri,

chitajte mi ribu.

Chitajte mi ribu

mojmu srcu libú.

4. Prví raz potiahli,

kalap mu vitiahli.

/: Ňije to tá riba

mojmu srcu libá. :/

5. Druhí raz potiahli,

Jaňíka vitiahli.

/: Toto je tá riba

mojmu srcu libá. :/ 


\section{Príklad 4}

Lúbostná pieseň, spev: neznámy, zber a zápis: Anton Cíger, 1930 - 1955, Stará Pazova

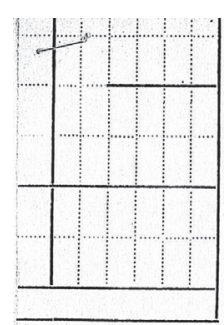

Ústav hudobnej vedy - Oddelenie hudobnej folkloristiky - SAV (Archív Pudových plesní)

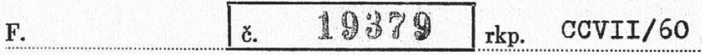

Ob. Stará Pazová Okr.

r. $1930-55$

Sp. r. Zap. Anton Cíger
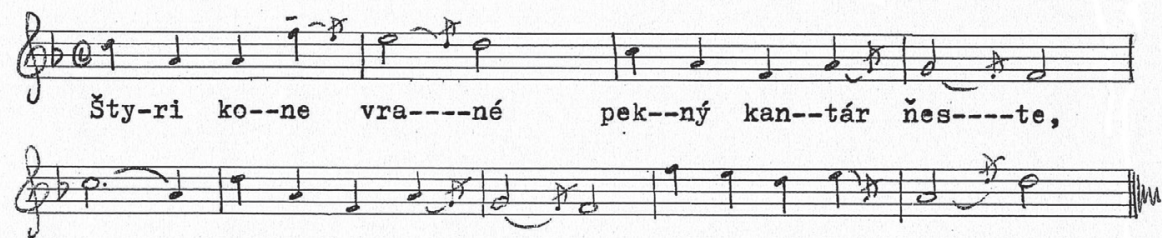

ej, dočkaj ma,diev--čat---ko, za tri rôč-ke eš-----te.

OuPZ 1372-61

1. Štyri kone vrané pekný kantár neste, ej, dočkaj ma, dievčatko, za tri rôčke ešte.

2. Čakala, čakala, od pov noci do dňa, ej, dokým ho dočkala, nebola mu honná. 


\section{Príklad 5}

a) Lúbostná pieseň, spev: neznámy, zber a zápis: Anton Cíger, 1930 - 1955, Stará Pazova
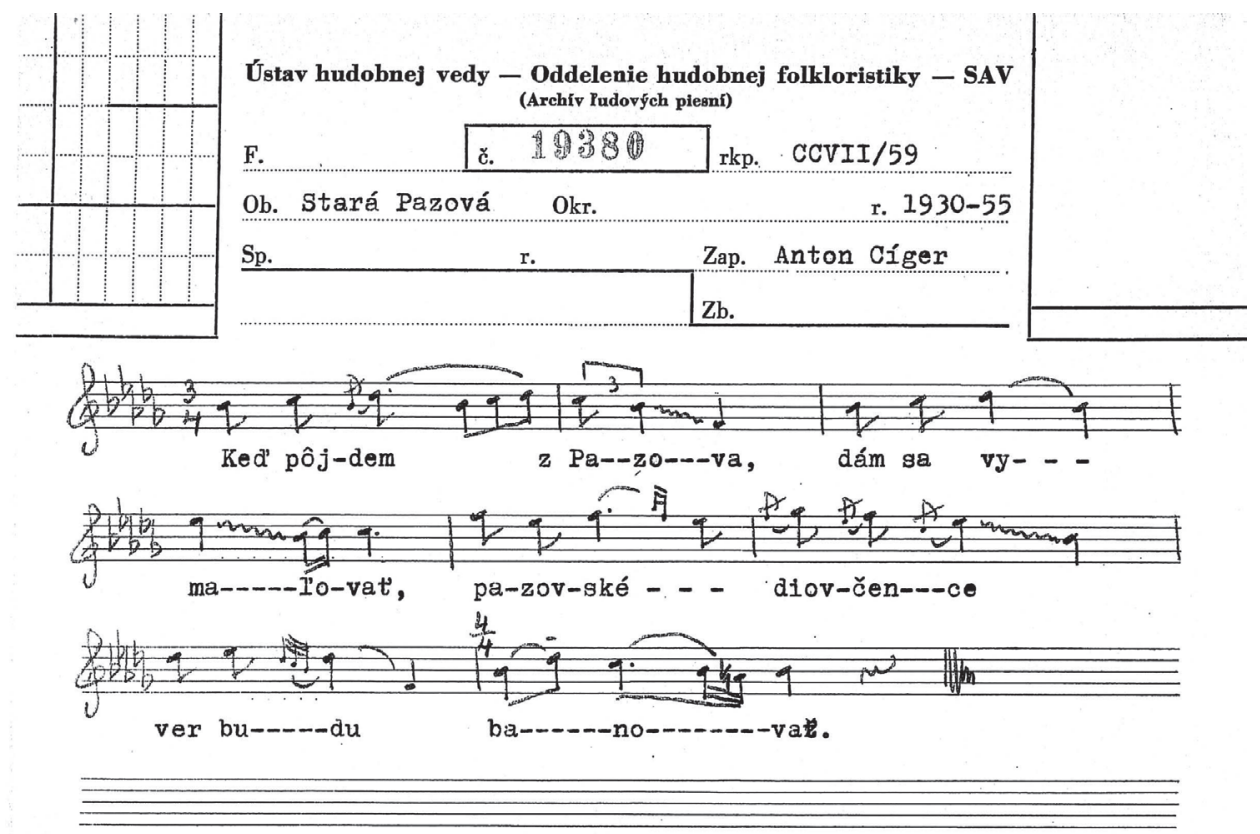

OUPZ 1372-01

2. Ked' pôjdem z Pazova, dám sa vymal'ovat', pazovské diovčence ver budú banovat'.

3. Banuj, diovča, banuj, máš za čím banovat, mala si frajera, nebudeš ho viac mat. 
b) Lúbostná pieseň, spev: Ján Pecník (1930 - 2020), zápis: Kristina Lomen, apríl 2014, Stará Pazova
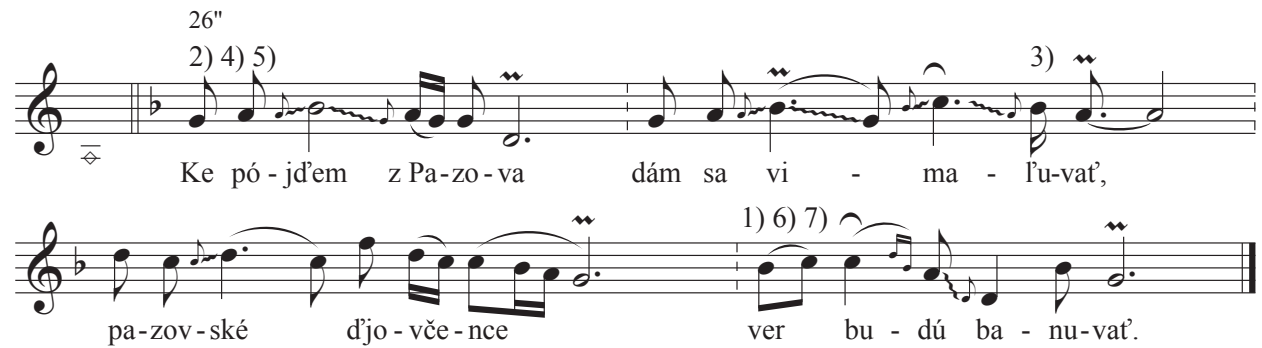

$\begin{array}{ll}\text { 1) 2. sfa, 3. sfa, 4. sfa } & \text { 2) 3. sfa }\end{array}$

3) 3.-6.sfa

4) 4. sfa, 6. sfa

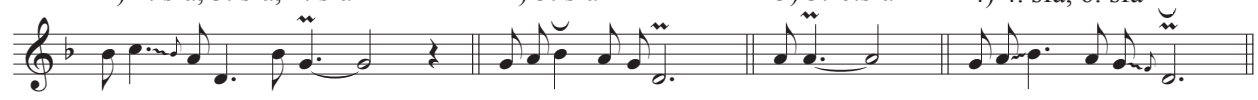

5) $5 . \mathrm{sfa}$

6) $5 . \mathrm{sfa}$

7) 6. sfa

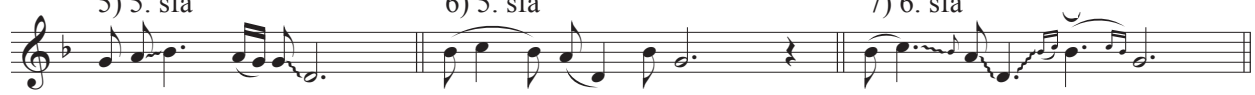

1. Ked' pójd’em z Pazova

dám sa vimaluvat', pazovské djovčence

ver budú banuvat.

2. Banuj djovča, banuj, máš za kím banuvat, mala si frajera, ňebud’eš ho viac mat'.

3. Mala si ho mala sedmorakej krási, mav vom čierňe oči, kučeravie vlasi.

4. Očká sa mu smejú, líčka červeňejú, a spod jeho srca slzi sa mu lejú.

5. Ňelejú, ňel'ejú, l’em kropaj' padajú, na marvam kemeňi jamke vivíjajú.

6. Marvam kemem, marvam, marvanova skala, šecka naša láska pod zemou ostála. 
Príklad 6

a) Vojenská pieseň, spev: neznámy, zber a zápis: Michal Litavský, medzivojnové obdobie, Stará Pazova

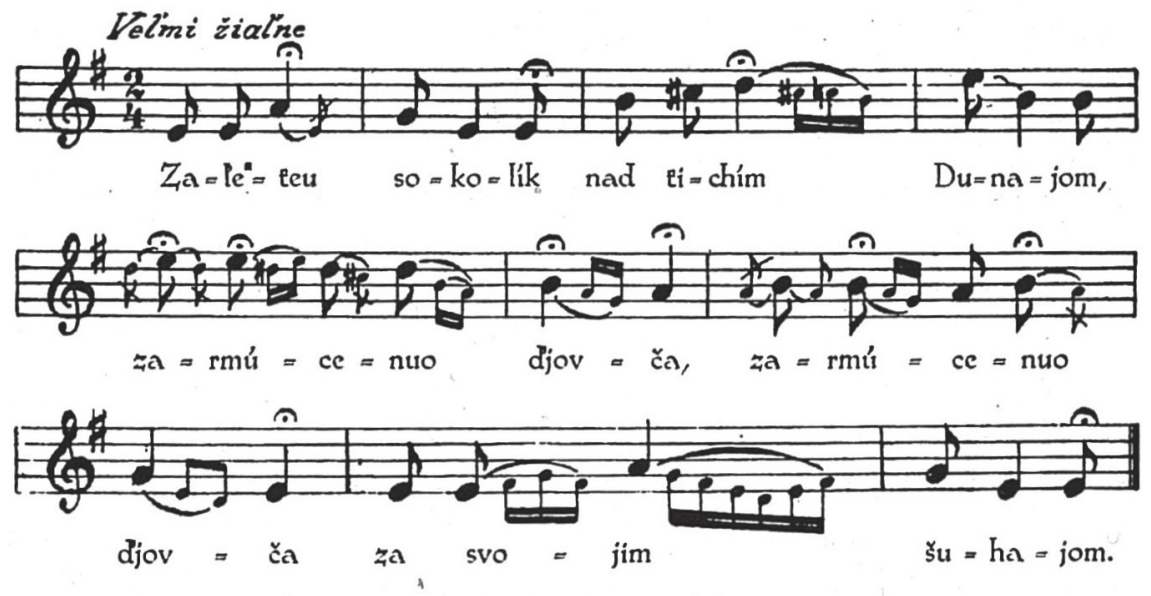

Zarmúcenuo plače, lem slzi viljeva, [: že jej frajer verní:]

$v$ špitále ondljeva.

V̌sitale ondljeva, leži v rozmaríne, [: ja som milá $v$ zámku:] $v$ Petrovaradiñe.
V Petrovaradiñe vojakov muštrajú, [: ej, mňa frajeročka :] obljeką uš tájdu.

Náš pán doktor tak nám včera povjedali, [: že ňepome domov:] aš tam $v$ januári. 
b) Vojenská pieseň, spev: Pavel Leštan (1964 - 2015), zápis: Kristina Lomen, apríl 2014, Stará Pazova
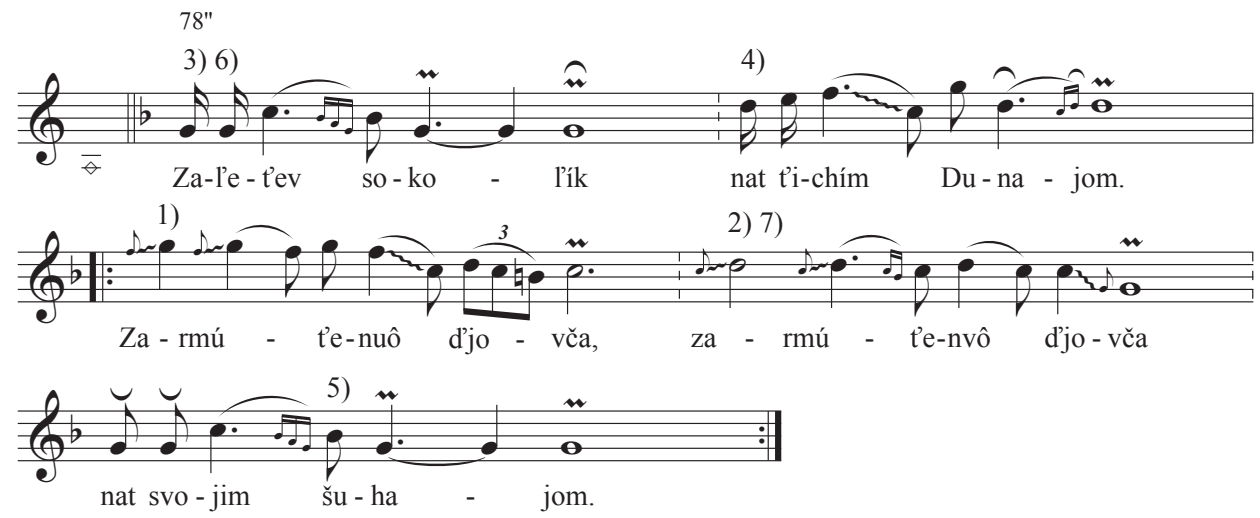

1) 1 . sfa pri op.,
2. sfa pri op.-4. sfa
2) 1. sfa pri op.-3. sfa
3) 2. sfa, 3. sfa

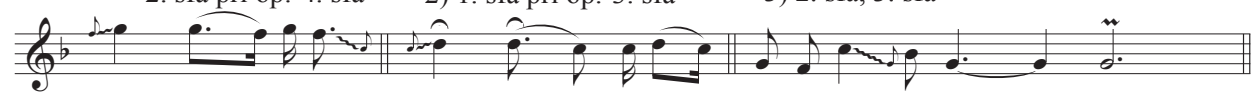

4) 2. sfa, 3. sfa
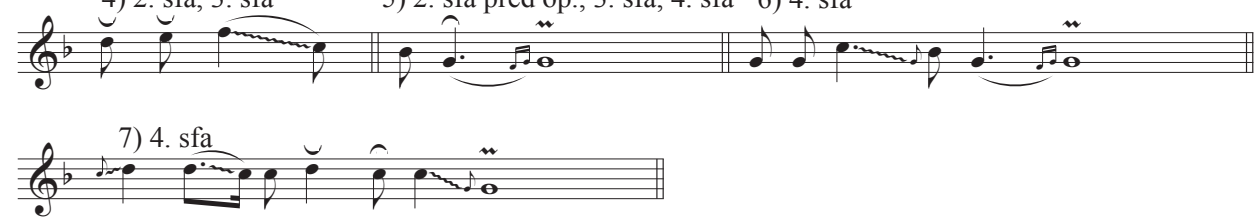

1. Zal'etev sokolík

nat tichím Dunajom.

/: Zarmútenuô djovča,

zarmútenvô djovča

nat svojim šuhajom. :/

2. Zarmútenuô plače,

aj slzi vilieva,

/: že jej frajer verňí,

že jej frajer verňí

f špitáli omdlieva. :/

3. Píše milej lístok,

leží rozmaríňe.

/: Ja som milá v zámku,

ja som milá v zámku

f Petrovaradiňe. :/

4. F Petrovarad'íne

vojakov muštrujú

/: aj mňa frajerôčka,

aj mňa frajerôčka,

obliekat uš tájdu. :/ 


\section{Príklad 7}

a) Lúbostná pieseň, spev: neznámy, zber a zápis: Michal Litavský, medzivojnové obdobie, Stará Pazova

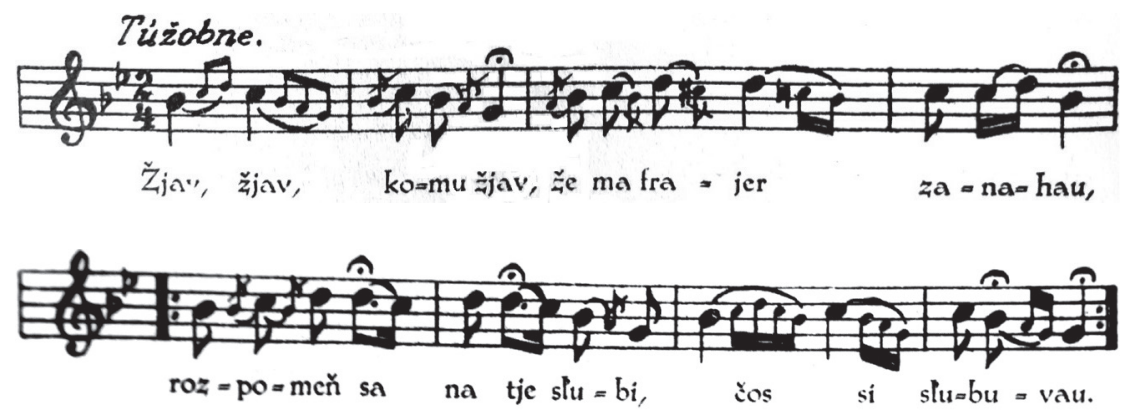

Slubuyau si mi

na tele $i$ na duši,

že sa naša verná láska

nigda nezruší.

Uš sa zrušila,

lebo že sa misela,

lebo že ei druhá milá

ručník višila.

$\checkmark$ pravom rošku dve slová, vo prostrjedku meno tvoje

- zlatá litera.

Bodaj si, milí,

ňemau noci ani drna.

Bohdau si bou v takom žjali,

ako co som ja. 
b) Vojenská pieseň, spev: Ján Pecník (1930 - 2020), zápis: Kristina Lomen, apríl 2014, Stará Pazova
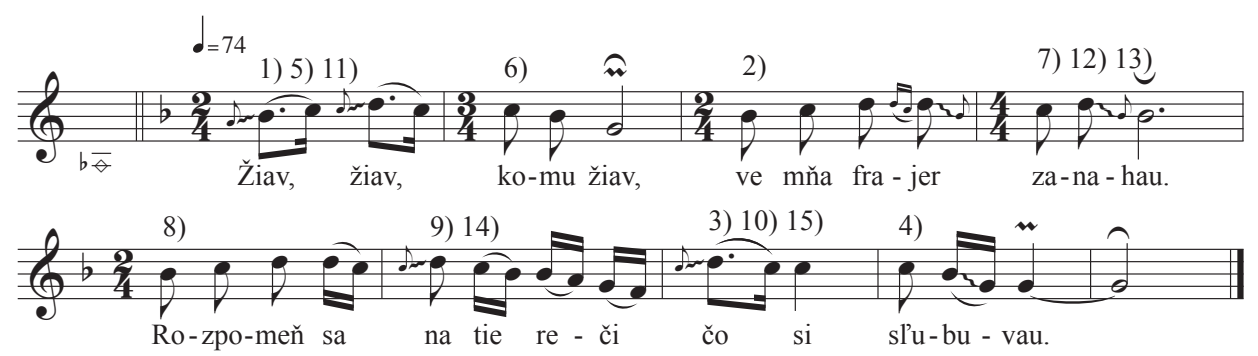
1) 2. sfa, 5. sfa
2) 2. sfa, 3. sfa
3) 2. sfa
4) 2.-5. sfa
5) 3. sfa

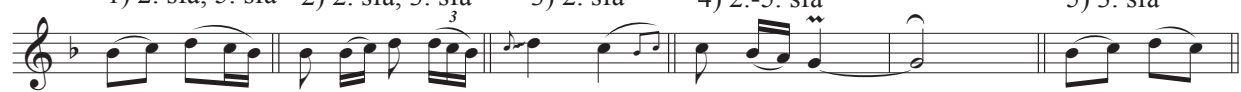

6) 3. sfa, 4. sfa

7) 3. sfa

8) 3. sfa

9) 3. sfa

10) 3. sfa, 4. sfa

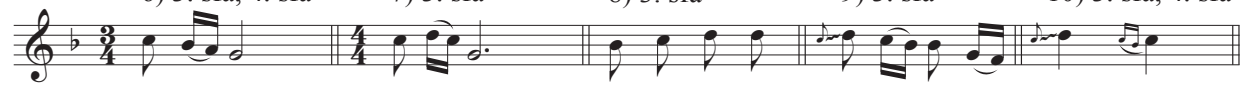
11) 4. sfa
12) 4. sfa
13) 5 . sfa
14) 5 . sfa
15) $5 . \mathrm{sfa}$

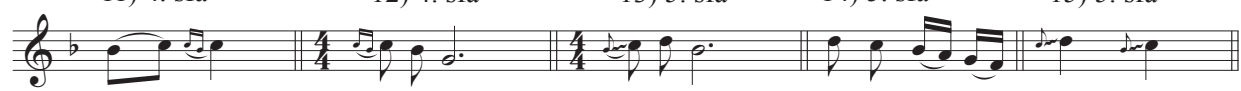

1. Žiav, žiav, komu žiav, ve mňa frajer zanahau.

/: Rozpomeň sa na tie reči čo si slubuvau. :/

2. Slubuvav si mi,

aj na t’el'e, na duši

/: že sa naša verná láska

ňigda ňezruší. :/

3. Už sa zrušila,

lebo že si mislela,

/: l'ebo že tỉ iná milá

ručňík višila. :/

4. Ručňík višila,

f každom tošku dve slová, vo prosriedku meno tvoje aj od koho je.

5. Bodaj si milí ňemau noci aňi dňa, /: abi si bou f takom žiali ako teraz ja. :/ 
Príklad 8

Vyst’ahovalecká pieseň, spev: neznámy, zber a zápis: Michal Litavský, medzivojnové obdobie, Stará Pazova

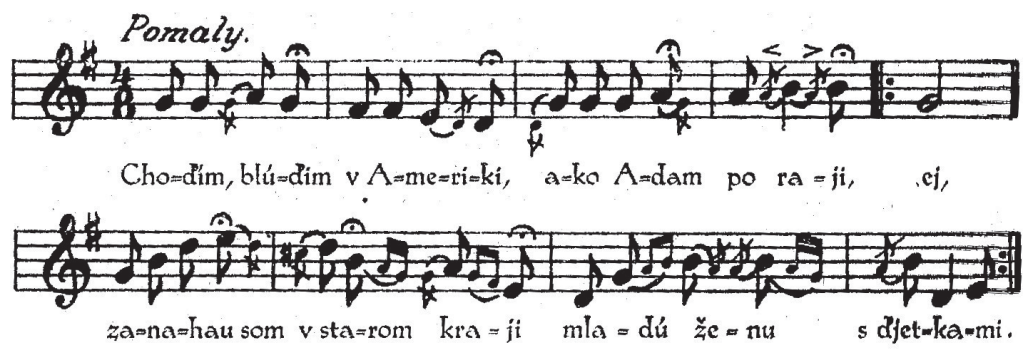

A ja som jej tak vr vjevau, že jej budem posílai, ei, a teras som pozabudou, že sa mi tam otec, mat. Teras som jej lístok písau, že dost dobre zarábem, ej, a to sa mñe velími páči, že ja nosím do kasi.
To je kasa velmi dobrá, lem interes ñedajú, ej, a ke tatam človek pride, na abštejz ho volajú.

Na tem abštejz, na tú postel, na tú postel drôtovú, ej, a tak som sa zakolimbau, ako šifa na mori.

\section{Príklad 9}

Lúbostná pieseň, spev: neznámy, zber a zápis: Karol Plicka, 1937, Stará Pazova

\section{EJ, ČO SOM UROBILA}

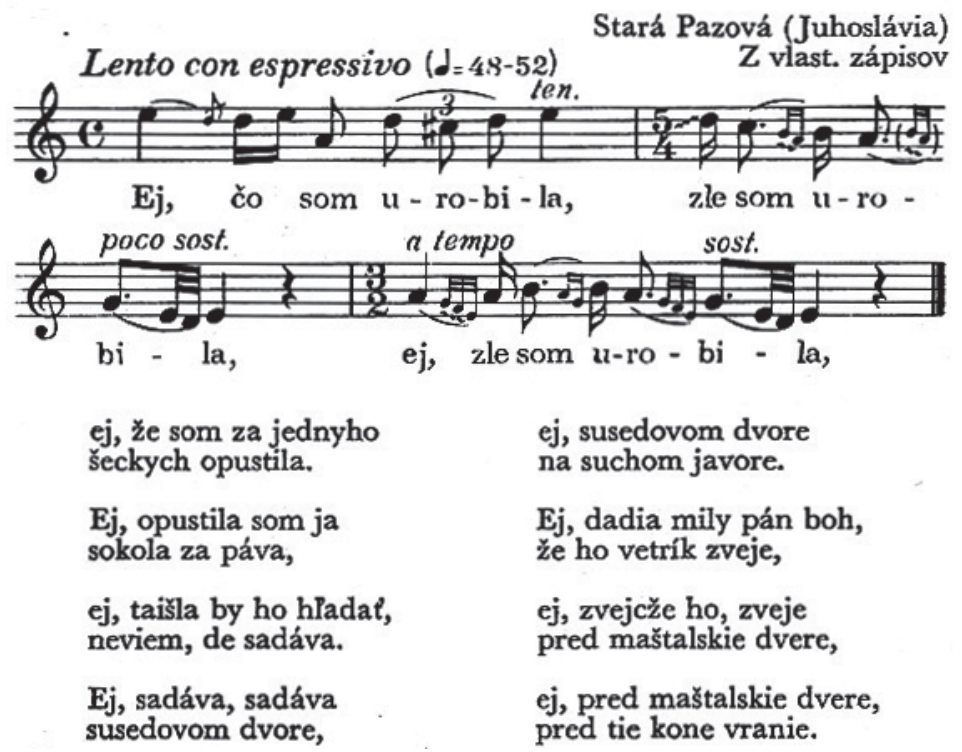


Príklad 10

Vojenská pieseň, spev: neznámy, zber a zápis: Karol Plicka, 1937, Stará Pazova

\section{NA GIMBALÁGH HRAJU}

Regrútska

Lento con espressione $(d=50-40) \quad Z$ vlast. zápisov

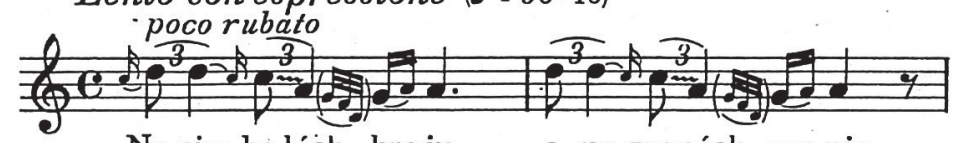

Na cim-bałách hra-ju a na zvonách zvo-nia,

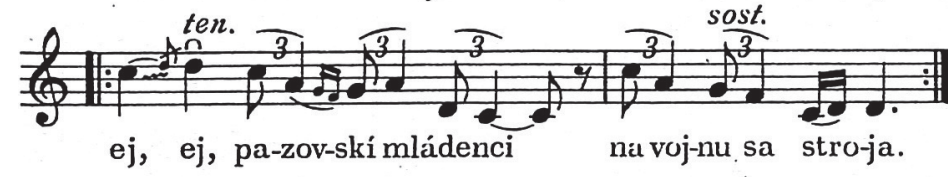

Jak sa oni stroja,

tak sa zhováraju,

ej, ej, pazovkie diovčence

zdravia ím vinšuju. 
Príklad 11

Lúbostná pieseň, spev: neznámy, zber a zápis: Karol Plicka, 1937, Stará Pazova

\section{KEĎ POJDEM Z PAZOVA \\ Večerná pieseň mládencov}

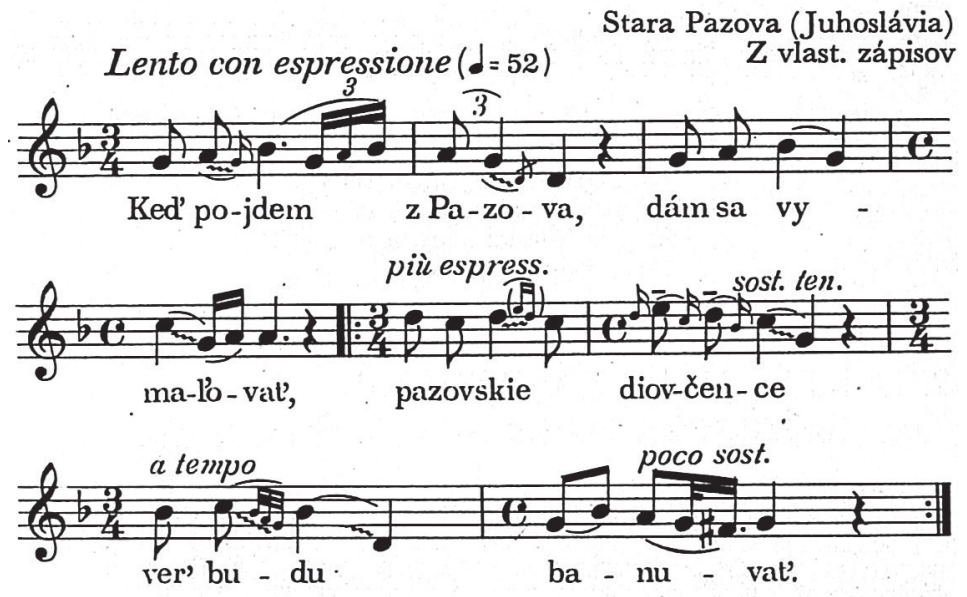

Banuj, diovča, banuj, máš za kým banuvat', mala si frajera, nebudeš ho viac mat.

Očká sa mu smeju, líčka červeneju, spod jeho srdiečka slzy sa mu leju.

Mala si ho, mala, nebudeš ho viac mat', má on čierne oči, kučeravie vlasy.

Neleju, neleju, len kropaj'. padaju, na marmor kemeni janke vybíjaju.

Marmar, kemem, marmar, marmarova skala, šetka naša láska pod tebou ostála. 
Príklad 12

Zbojnícka pieseň, spev: Ana Verešová, zber a zápis: Karol Plicka, 1937, Stará Pazova

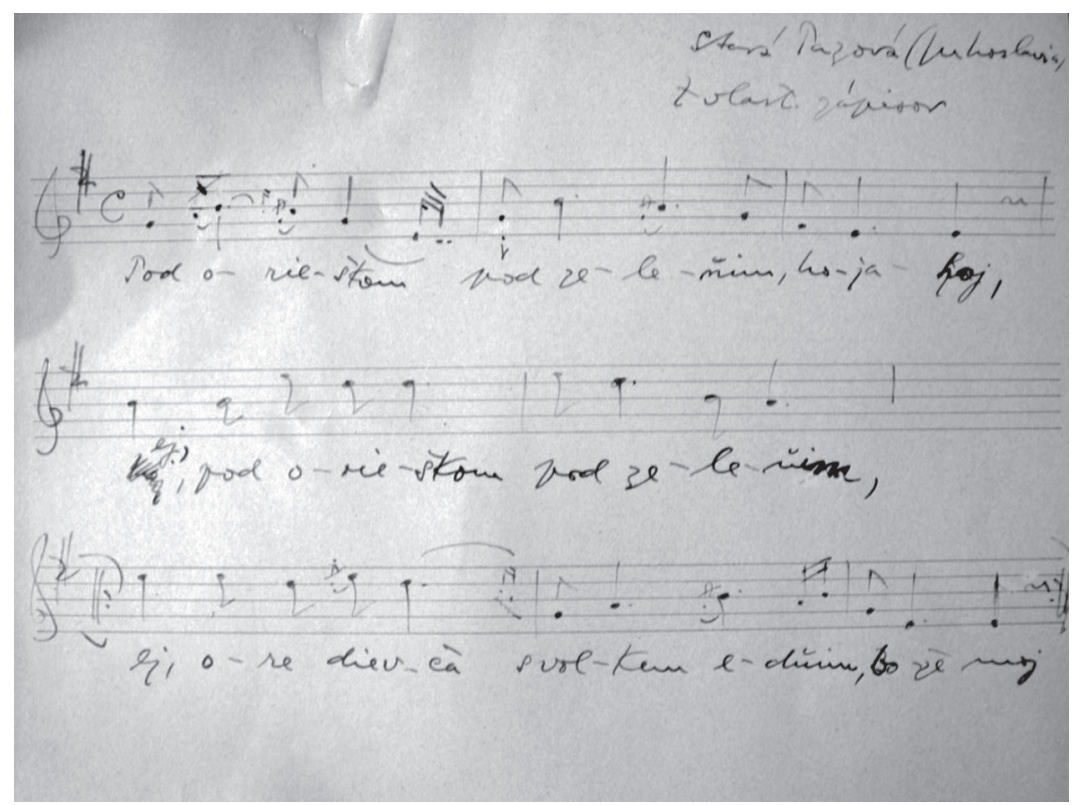

Príklad 13

Lúbostná pieseň, spev: Jozef Havran (1899 - 1982), zber a zápis: Jozef Kresánek, 1947, Stará Pazova

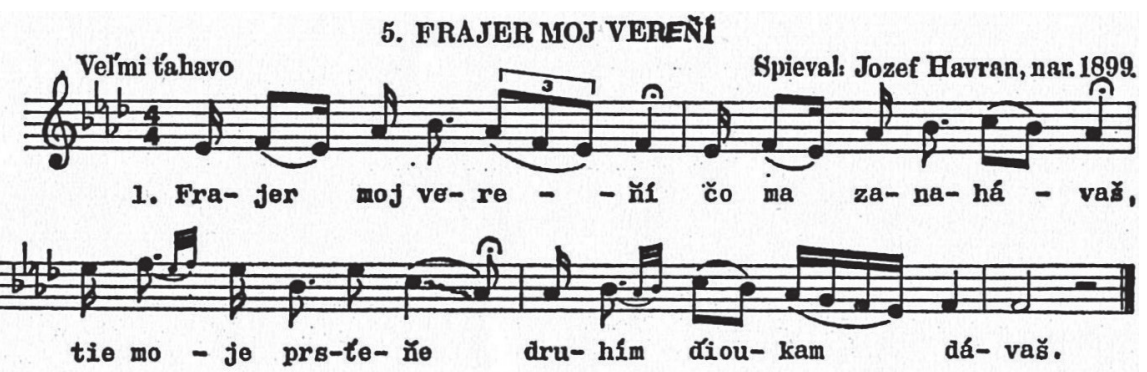

2. Druhím đ’ioukam dávaš a mňa zanahávaš, vínd'eš predo dvere, tam ma ohováraš.

3. Višou predo dvere, a utreu si očká, bohu ta porúčam, moja frajeruočka.
4. Bohu ta porúčam, zdravia ti vinšujem, za frajersku lásku, pekňe ti d'akujem.

5. Neđakuj, ňeđakuj, ve ešte prid'es̉ $\mathrm{k}$ nám, na sobotu večer, peknuo ti pierce dám. 


\section{Príklad 14}

Lúbostná pieseň, spev: Juraj Ondrík st. (1909 - 1989), zber a zápis: Jozef Kresánek, 1947, Stará Pazova

\section{POD JAVORŇÍCKKOM BISTRÁ VODA}
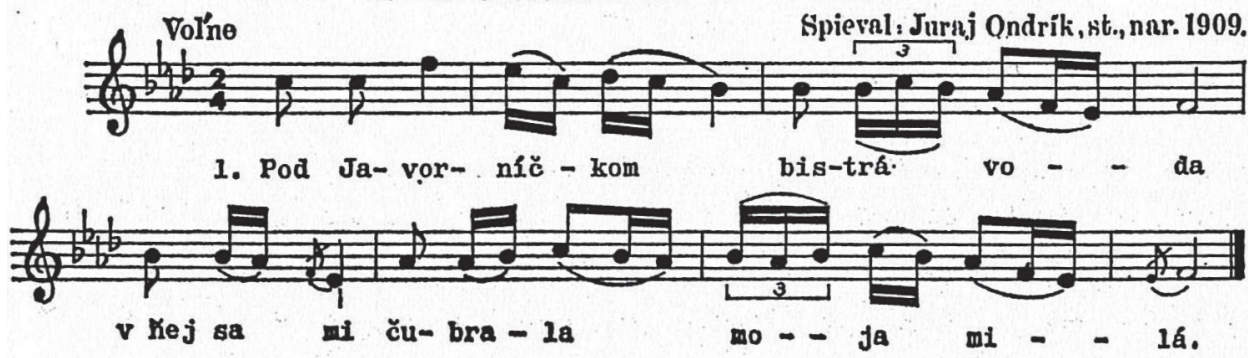

Príklad 15

Vojenská pieseň, spev: A. Čapová (1906 - 199[?]), zber a zápis: Juraj Ferík st., 1956, Stará Pazova

\section{Pri mitrouskej bráni}

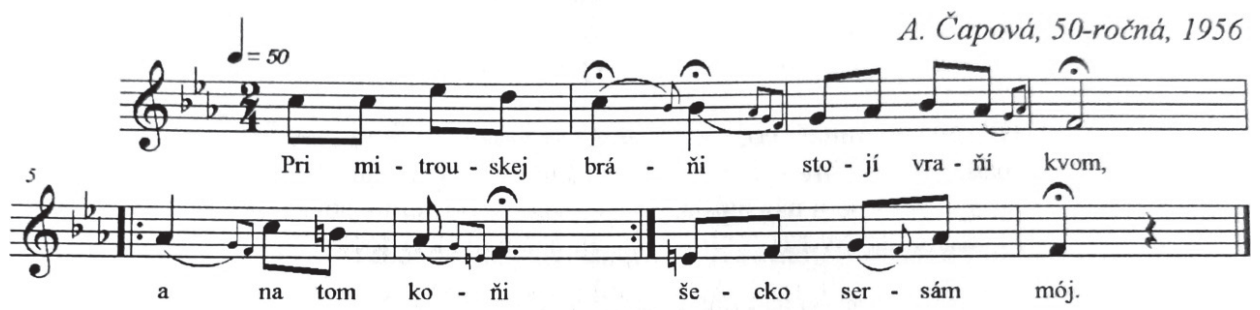

1. Pri mitrouskej bráňi stojí vraňí kvom,

2. Ešt'e na tom koňi, visí šabličcka, \|: A na tom koňi :\| šecok sersám mój.

\|: Čo sa bó bráňit’ :\| moja hlavička.

3. Ot'ec je obrster, a sim gemajner,

Čo zlato nosí, zahinút' misí, ako gemajner. 
Príklad 16

Lúbostná pieseň, spev: M. Filipová (nar. 194[?]), zber a zápis: Juraj Ferík st., 1952, Stará Pazova

Na priadkach 409. Lastovienka l'ieta

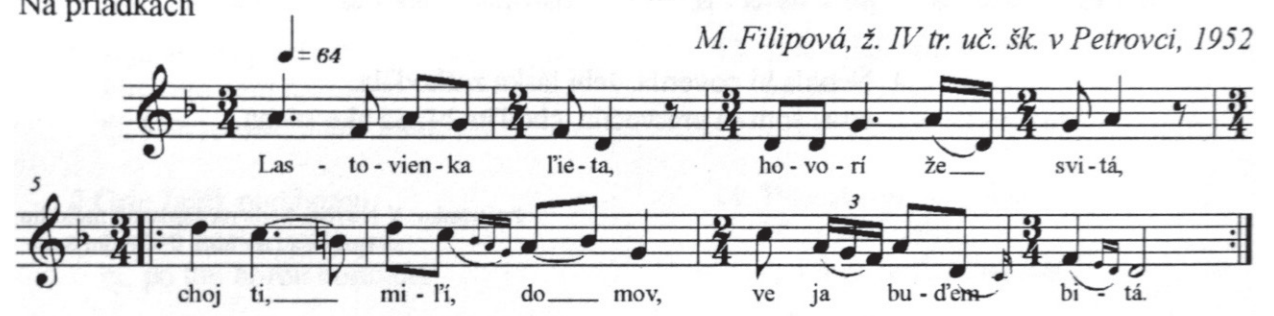

1. Lastovienka lieta, hovorí že svitá, choj ti milí domov, ve ja bud'em bitá.

2. Ve ja bud'em bitá od mojej mamički, že som ňenažala zel'enej trávički.
3. A ja bud'em bití od mojho tat'ǐka, že som ňenapojiu vraniho koňíčka.

4. A ja bud'em bit'í aj od mojho d'edu, že ma každuo rano od mámiléj vedú.

\section{Príklad 17}

Vojenská pieseň, spev: Ján Litavský (nar. 1926), zber a zápis: Juraj Ferík st., 1956, Stará Pazova

Vojenská

\section{Ke zme Varad'iňe}

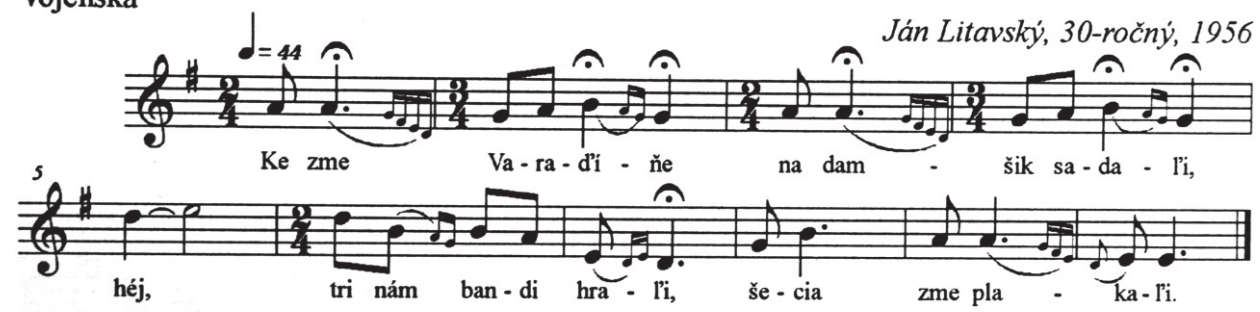

1. Ke zme Varad'íňe na damšik sadali, héj, tri nám bandi hrali, šecia zme plakali.

2. A tie naše manki za nami plakali, héj, d'et'i naše d'eti, d'e nám tajdu $\mathbf{s}$ vami.

3. Tájdu oni, tájdu do taljanskéj zemi, héj, do taljanskéj zemi, tam zahinut's nami.
4. Tal'janska, tal'janska dost' krvi prel'iala, héj, ňejedna mamička sina oplakala.

5. A ke si pomislím na pazouské zvoni, héj, na zvoni pazouské, na oltár pazouskí.

6. A na tom oltári, červená ružička, héj, ešt'e červeňejšie mojej milej líčka. 
Príklad 18

Pieseň na svadbe, spev: Zuzana Slančíková (1908 - 1988), zápis: Ladislav Leng, 196[?], Stará Pazova

Rubato $\quad \cdot=66-76$

6. Ňinto po povnoci
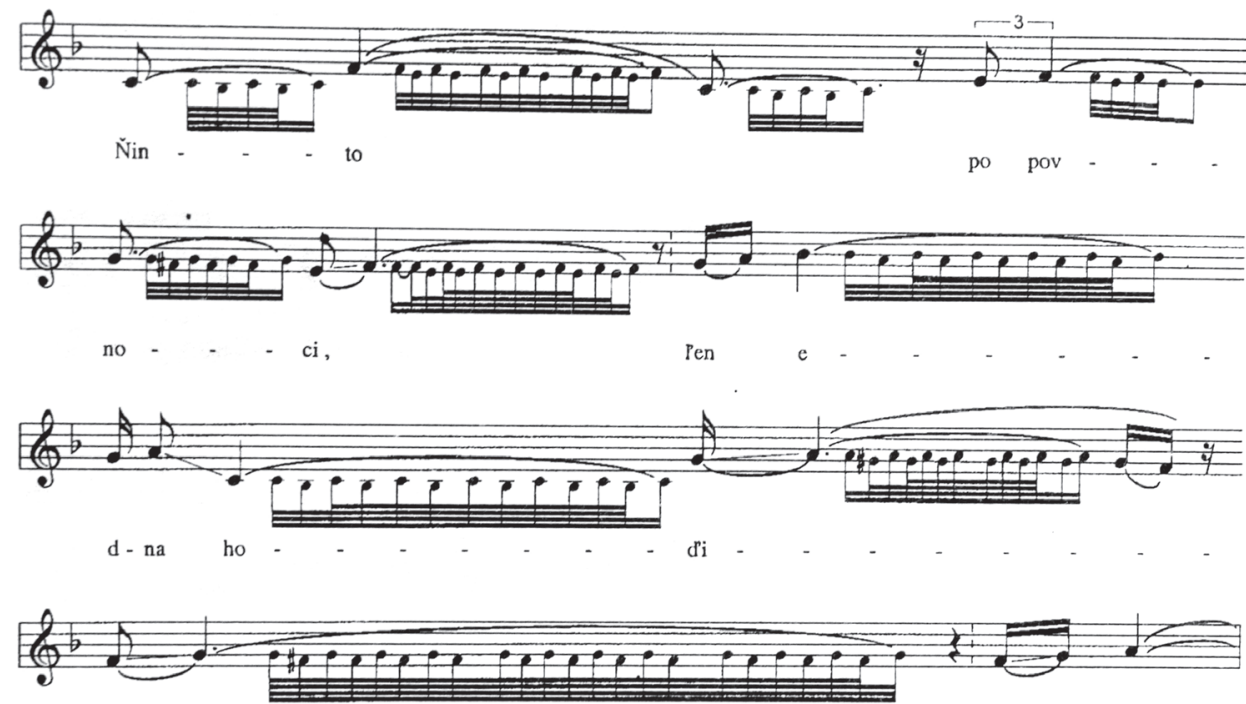

na ,
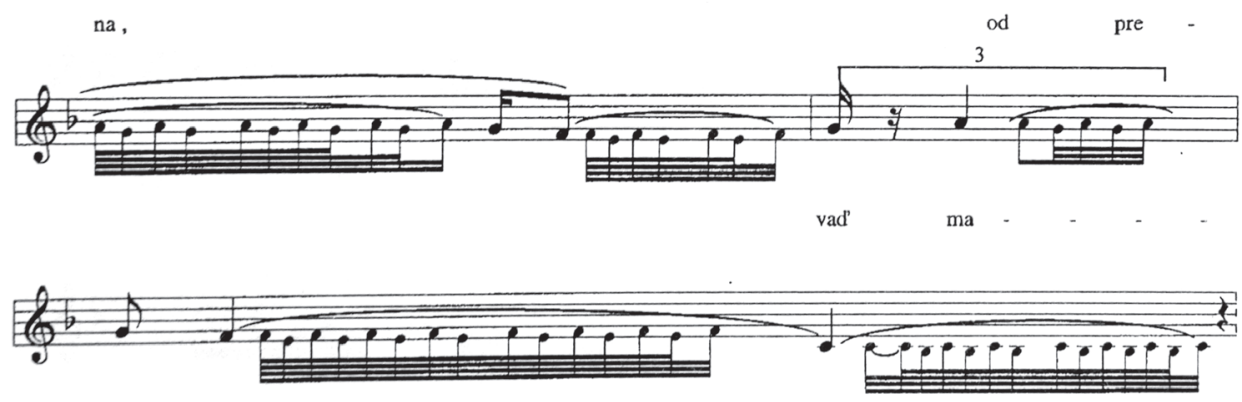

mi - lá,

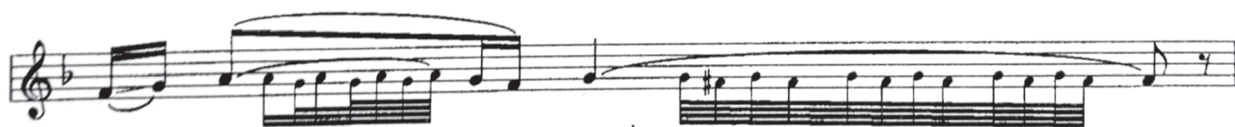

mi - lá

du

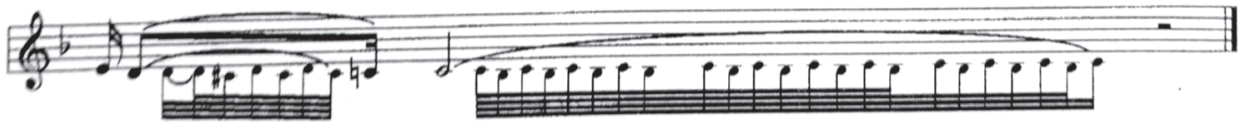

sa mo

ja 
Príklad 19

Lúbostná pieseň, spev: Juraj Ondrík st. (1909 - 1989), zápis: Ladislav Leng, 196[?], Stará Pazova

\section{AJ, POL'A NÅg, POLA NÁS}
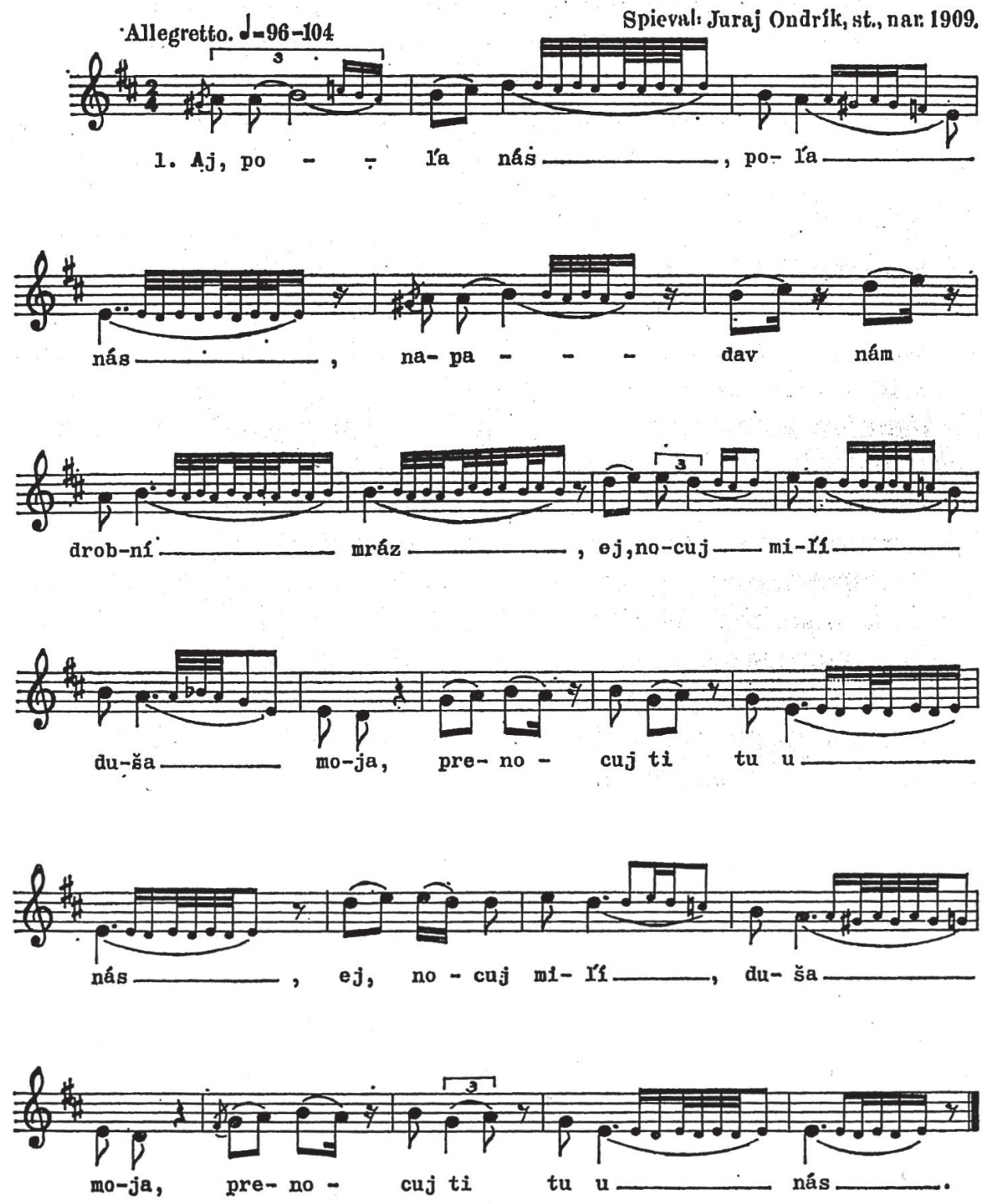
2. A ja bi prenocuvau, zaspau bi som do rána, (:ej, ňi bi, mili, duša moja, zobud’ila bi ta ja.:)
3. Zobudila bi ta ja, ked’ bi bou už bieli d’em, (:ej, žebi Pud’ia povrávaPi, že od volkou ja id’em.:)

4. స̌i od volkou, od koňi, od má milej s komori.:)

(:ej, ňi od volkou, aj od koňí, od má milej s komori,

Príklad 20

Vojenská pieseň, spev: Juraj Ondrík st. (1909 - 1989), zápis: Ladislav Leng, 196[?], Stará Pazova

\section{KED ZME IŠ̆Ĺ DO MANTAVE}
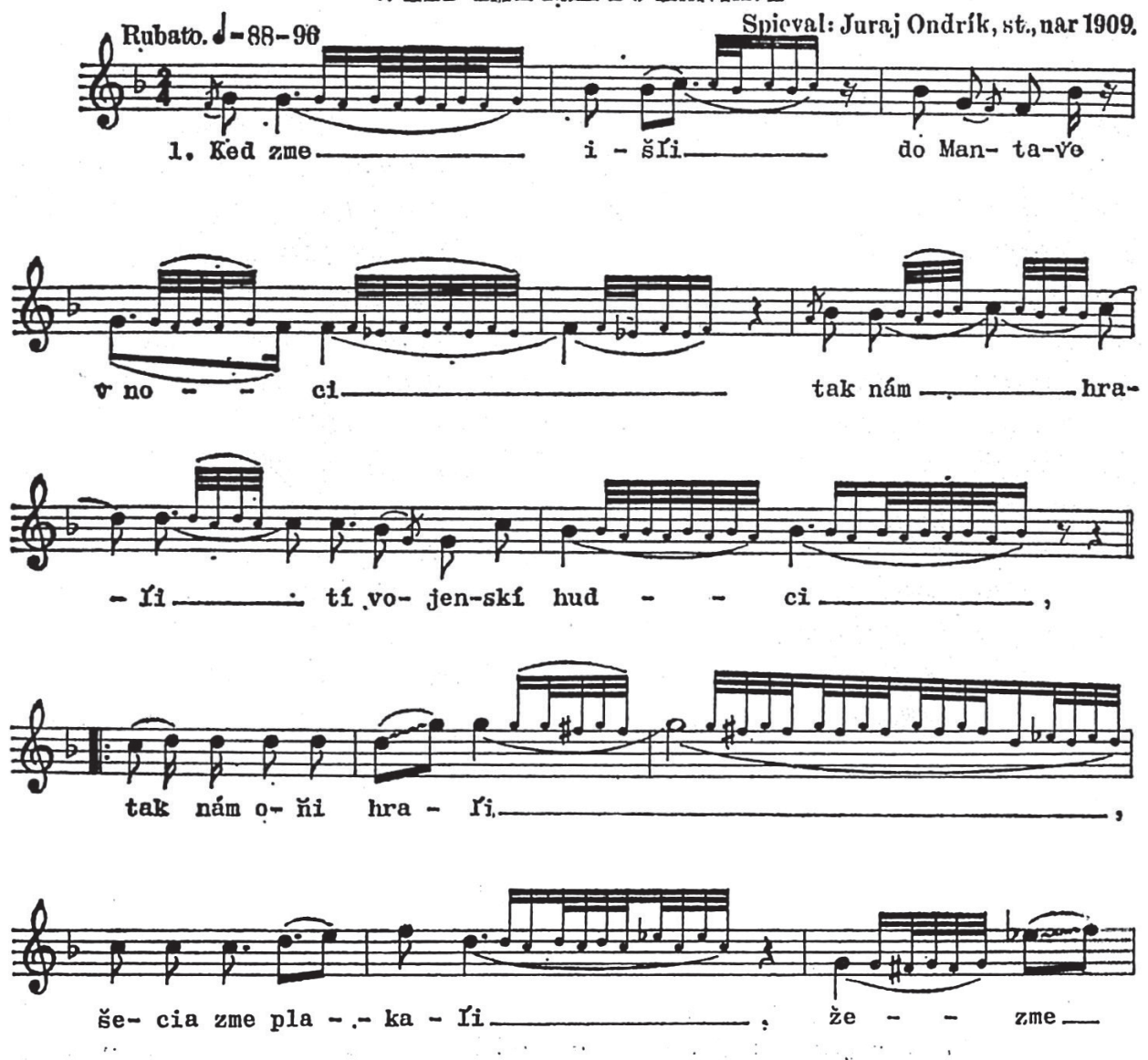


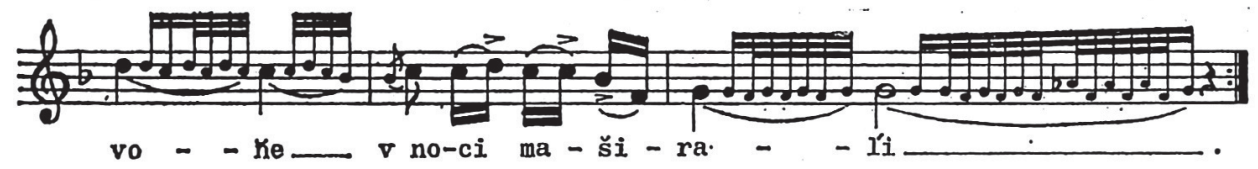

2. Počau na nás tỉchí daždik padat, počã î zme do kasárňou vchádzaf:;

(:kasárňa prekrásna, ma milá, ohlás sa, či počuješ ešte mojho hlasa.:)

Príklad 21

Vojenská pieseň, spev: neznámy, zber a zápis: Martin Kmet', 196[?], Stará Pazova
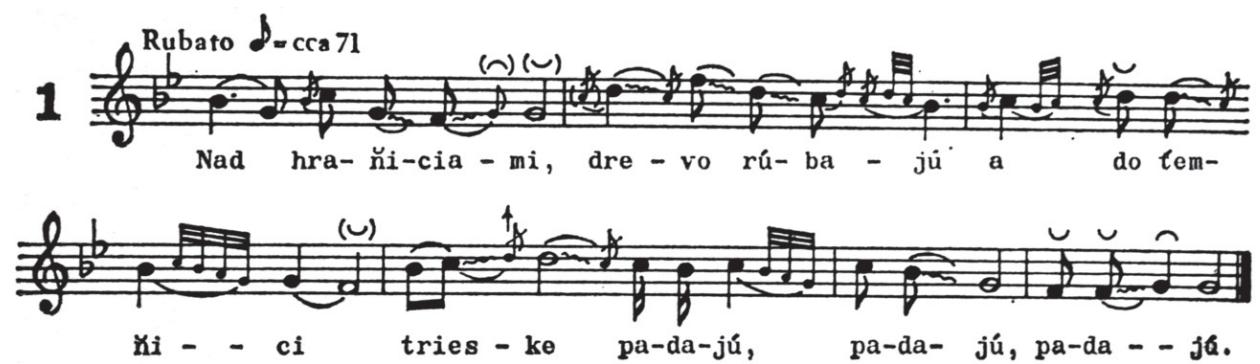

Príklad 22

Vojenská pieseň, spev: neznámy, zber a zápis: Martin Kmet', 196[?], Stará Pazova
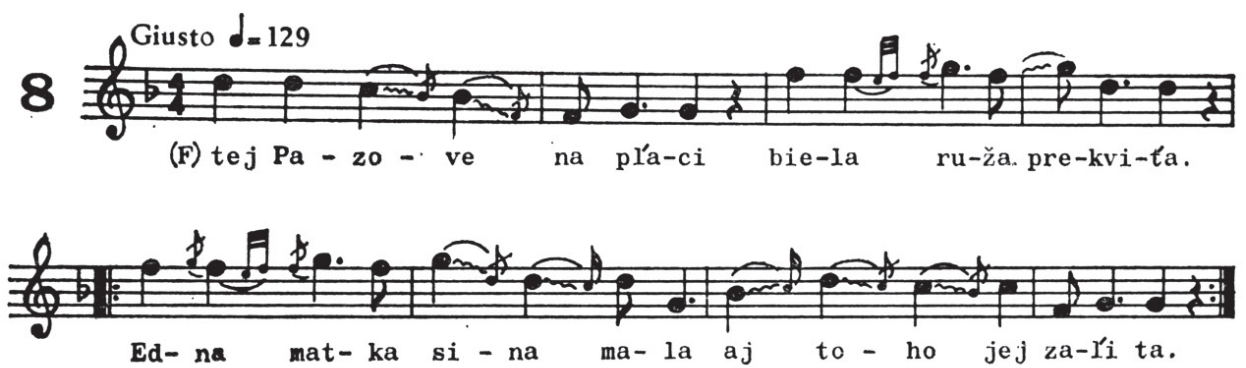


\section{Príklad 23}

Vojenská pieseň, spev: neznámy, zber a zápis: Martin Kmet', 196[?], Stará Pazova

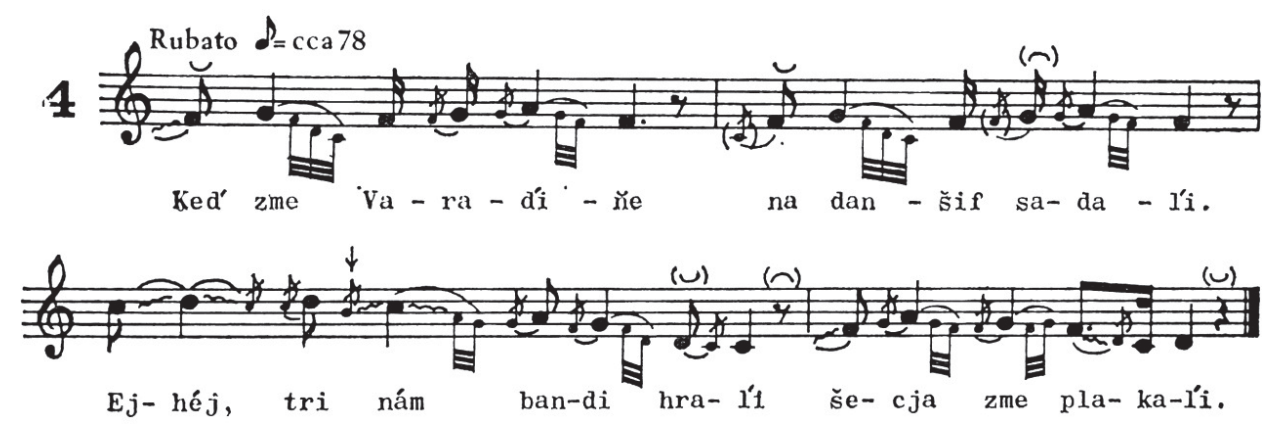

\section{Príklad 24}

Vojenská pieseň, spev: Pavel Leštan (1964 - 2015), zápis: Kristina Lomen, apríl 2014, Stará Pazova
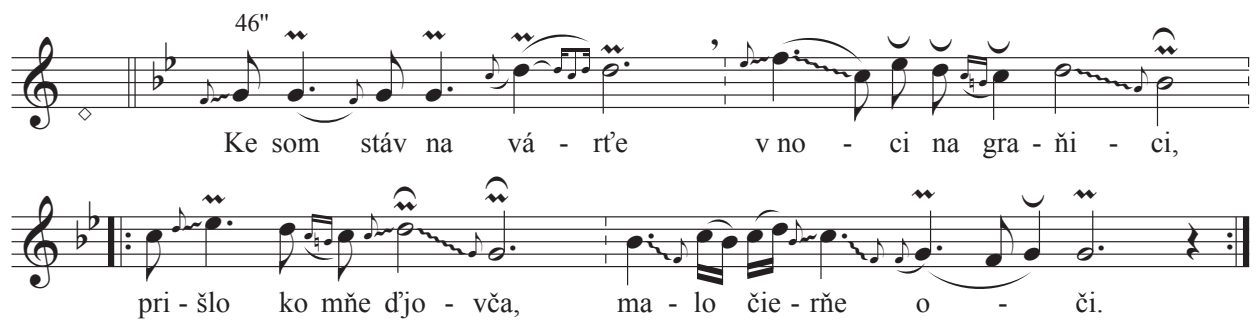

1. Ke som stáv na várte $\mathrm{v}$ noci na graňici,

/: prišlo ko mňe djovča, malo čierňe oči. :/

2. Pri mňe ono stálo, žalosňe plakalo, /: z bieleňím ručňíkom očká utieralo. :/

3. Ňeplač djovča, ňeplač, nehub svoje oči.

/: Bolo ti plakati, ke som chodiu v noci. :/

4. Staja muruvaná, a v ňej koňík vraňí, /: sedlaj si ho Jaňík, Jaňík šňúruvaňí. :/ 


\section{Príklad 25}

Regrútska pieseň, spev: Pavel Leštan (1964 - 2015), zápis: Kristina Lomen, jún 2014, Stará Pazova
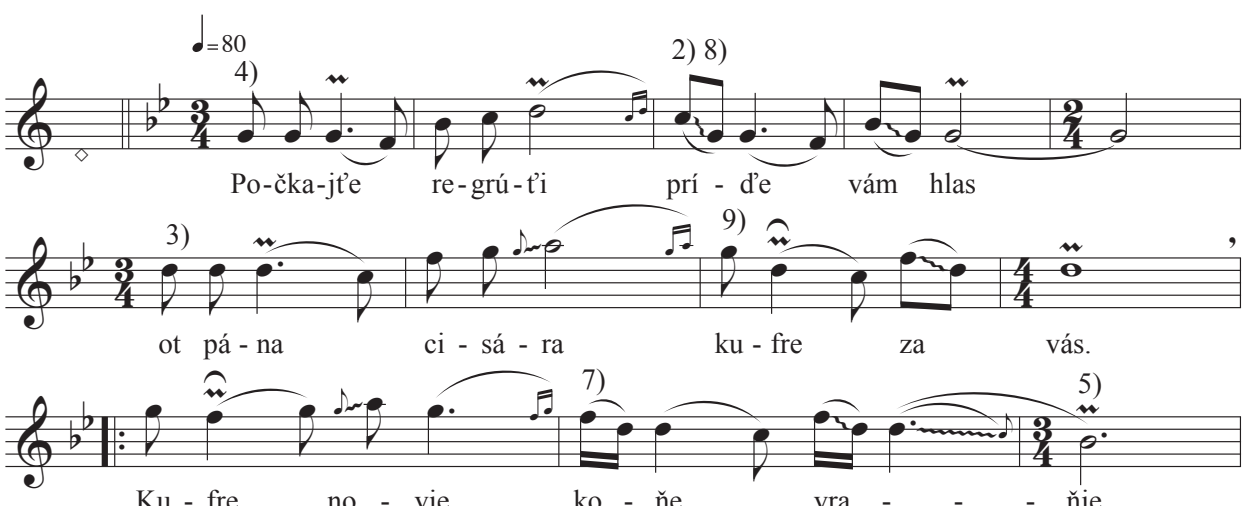

6)

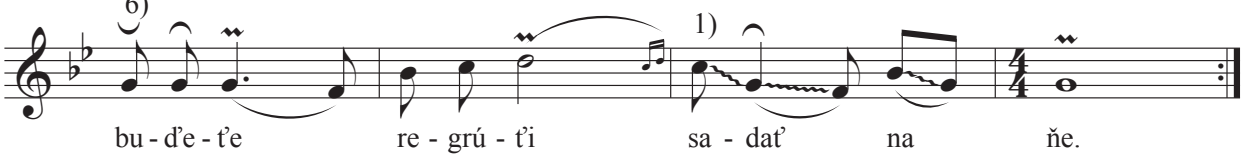
1) 1. sfa pri op.
2) 2. sfa, 3. sfa
3) 2.-5. sfa
4) $3 .-5 . \mathrm{sfa}$
5) $3 .-5 . \mathrm{sfa}$

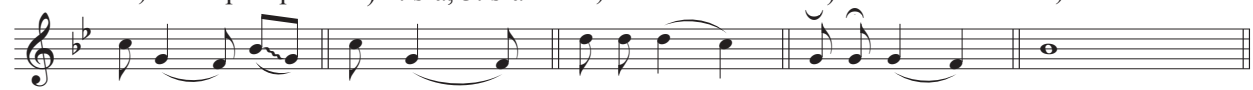

6) 3.-5. sfa

7) 4. sfa, 5. sfa

8) 5 . sfa

9) 5 . sfa

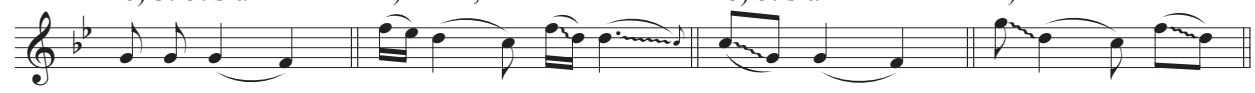

1. Počkajte regrúti príd’e vám hlas ot pána cisára kufre za vás.

/: Kufre novie, koňe vraňie, bud'et’e regrúti sadat' na ňe. :/

2. Ke zme mi na koňe visadali, šeckím nám mamičke zaplakali.

/: Jaj mamička, čo plačete, ve vi ta tam s nami ňepójd’ete. :/

3. Ako bi zme smutňie ňeplakali, ke zme vás mi taško vichovali. /: Ťaško, taško ako ftákov, pána cisárovi za vojákov. :/
4. Podaj mi mamička tú sviečočku, nak si ja posvietim tú cestičku. Či je sucho a či blato a či je cestička samuô zlato. Ňije sucho, aňi blato, ale je cestička samuô zlato.

5. Podaj mi kamarát sviečočku, nak si ja posvietim frajerôčku. Či je moja, a či tvoja, a či je frajerka pajtášova. Ňije moja, aňi tvoja, ale je frajerka pajtášova. 


\section{Príklad 26}

Lúbostná pieseň, spev: Vladimír Žolnaj (nar. 1964), zápis: Kristina Lomen, apríl 2014, Stará Pazova

1) 4$)$

5) $3-2$ 2)
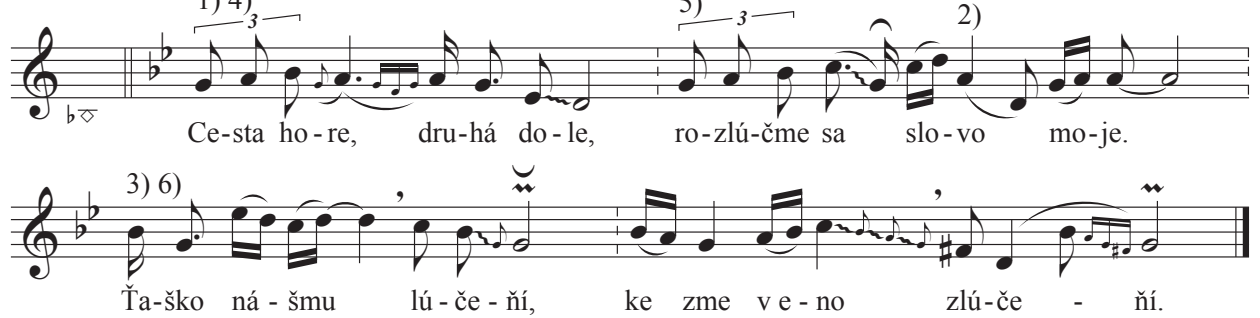

1) $2 . \mathrm{sfa}$

2) 2. sfa

3) 2. sfa pred op.

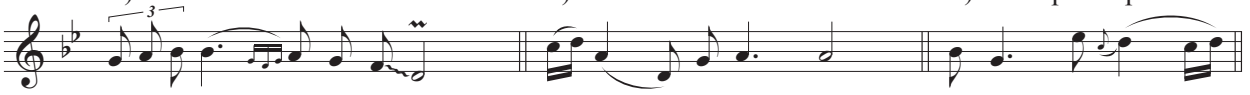
4) 3. sfa
5) 3. sfa
6) 3. sfa pred op.

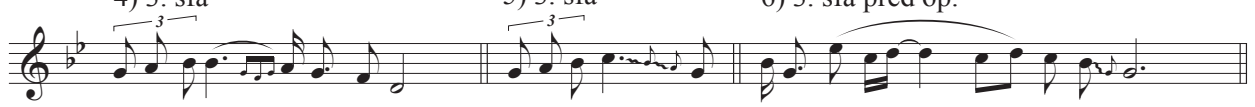

1. Cesta hore, druhá dole, rozlúčme sa slovo moje.

/: Ťaško nášmu lúčeňí,

ked' zme v eno zlúčeňí. :/

2. Vrát mi milá čo som ti dau,

ke som ja k vám chodievávau.

/: Čo si mi dau takího,

že banuješ tak velmo. :/

3. Dau som ti ja prstem zlatí,

čo koštuvau tristo zlatích.

/: A ja tebe ručňíčok,

to nám bud’e rozlúčok. :/ 


\section{Príklad 27}

Balada, spev: Anna Šagová (nar. 1980), zápis: Kristina Lomen, apríl 2014, Stará Pazova
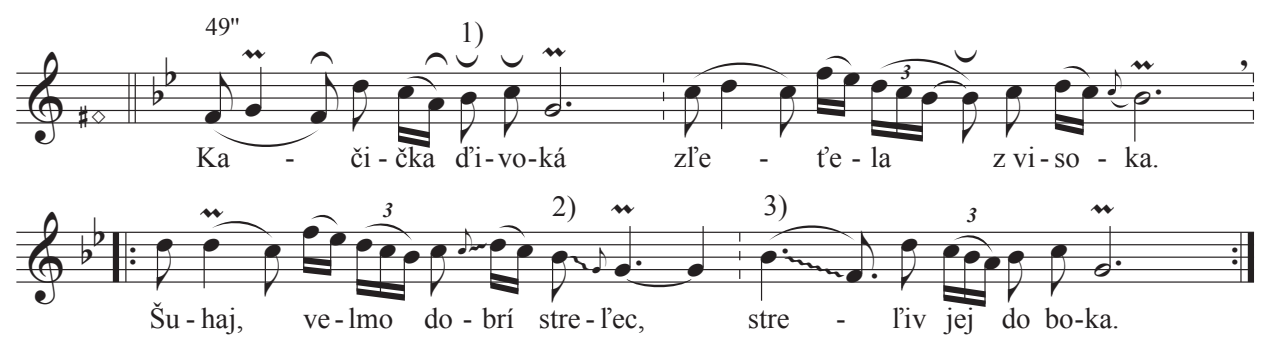
1) 2. sfa
2) $3 . \mathrm{sfa}$
3) 4. sfa pred op.

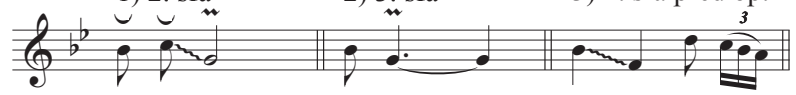

1. Kačička divoká zletela $\mathrm{z}$ visoka.

/: Šuhaj, velmo dobrí strelec, streliv jej do boka. :/

2. Odstreliv jej krídlo aj pravú nožišku. /: Horko zaplakala, sadla na vodičku. :/

3. Milí, mocňí Bože, už som dolietala, /: už som si ja moje drobnie deti vichovala. :/

4. Moje drobnie deti na kameňi sedia. /: Kalnú oňi vodu pijú, drobňí piesok jedia. :/ 


\section{Príklad 28}

Lúbostná pieseň, spev: Anna Šagová (nar. 1980), zápis: Kristina Lomen, apríl 2014, Stará Pazova
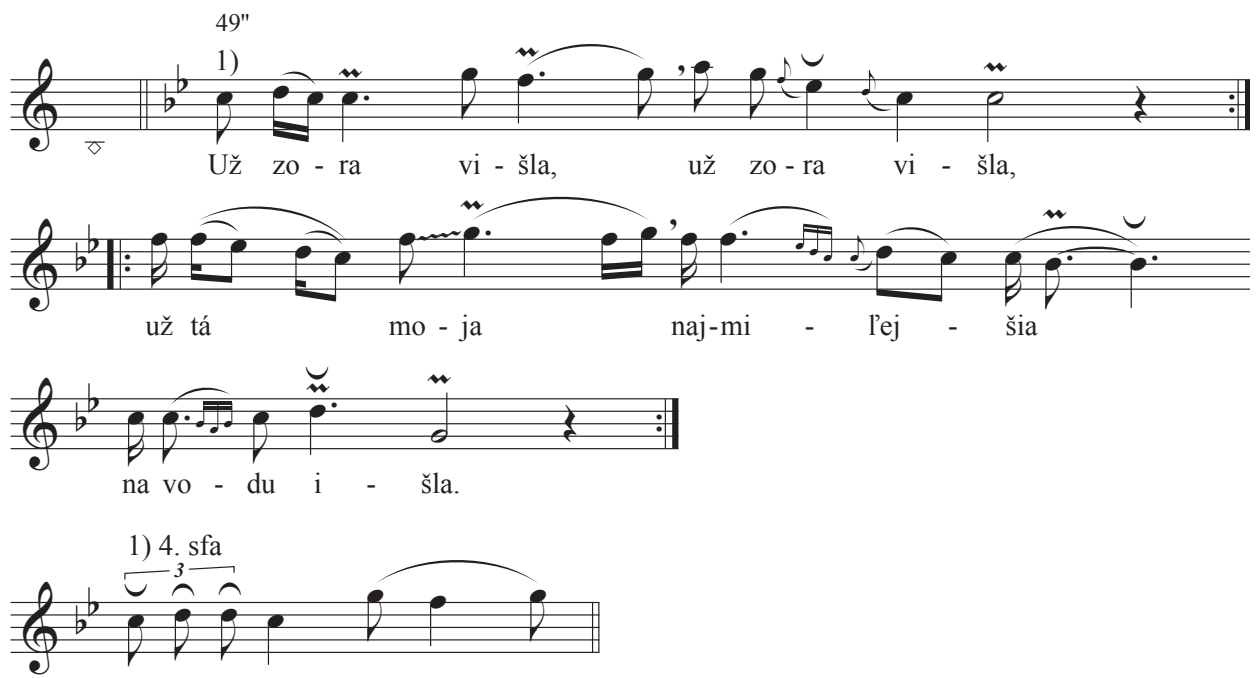

1. /: Už zora višla, už zora višla, :/

/: už tá moja najmil'ejšia na vodu išla. :/

2. /: Počkaj mámilá napoj mi koňa. :/

/: Zo studňički virúbeňej, Z novího vedra. :/

3. /: Ja ňenapojím, ja sa ho bojím. :/ /: Ňenapojím, ja sa bojím, ňeni som ja tvá. :/

4. /: Ked' ja bud’em tvá, napojím ti dva, :/ /: zo studňički vizrúbeňej, z novího vedra. :/

5. /: Kôm vodu pije, nohami bije. :/ /: Merkuj že sa moja milá, kôm ta zabije. :/ 


\section{Príklad 29}

Vystahovalecká pieseň, spev: Ján Pecník (1930 - 2020), zápis: Kristina Lomen, jún 2014, Stará Pazova
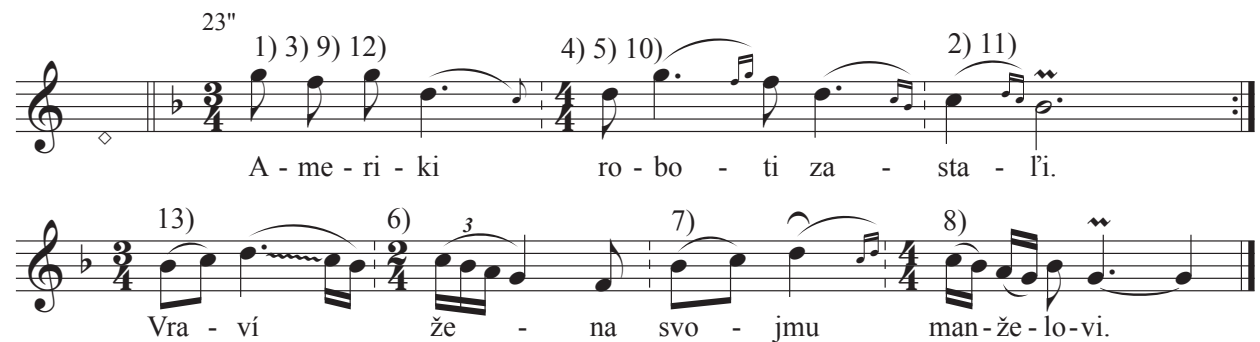

1) 1. sfa pri op., 2. sfa pri op.,

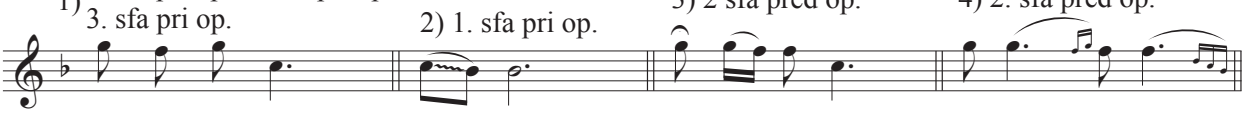

5) 2. -3. sfa pri op.

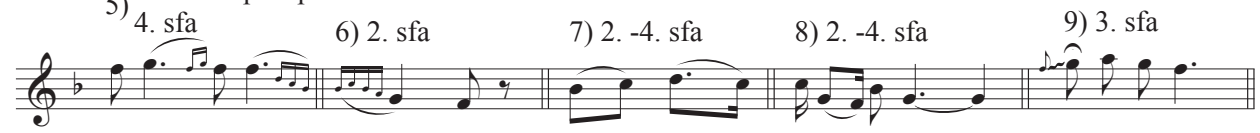

10) 3. sfa pred op.

11) 3. sfa pri op.

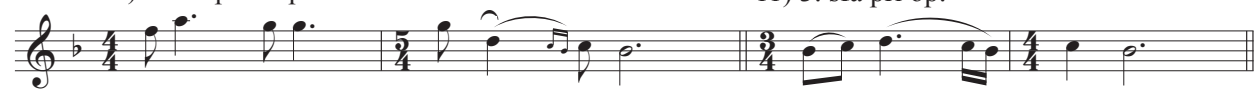

12) 4. sfa 13) 4. sfa

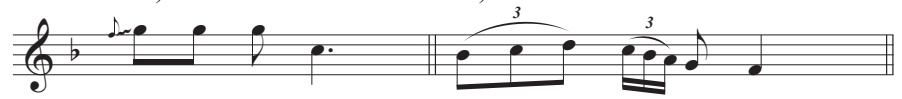

1. /: Ameriki roboti zastali. :/

Vraví žena svojmu manželovi.

2. /: Pome mužu do starího kraju, :/

ažda nám tam zas robotu dajú.

3. /: A čo bóme žena starom kraji robit, :/

ke ti nevieš aňi tkat', ani prat',

/: l’em po bálach valcere tancuvat'. :/

4. Naučím sa, mój mužíčku drahí,

naučím sa ja šecke roboti. 


\section{Príklad 30}

Svadobná obradová pieseň, spev: Mária Hrehorová (nar. 1950), zápis: Kristina Lomen, október 2014, Stará Pazova
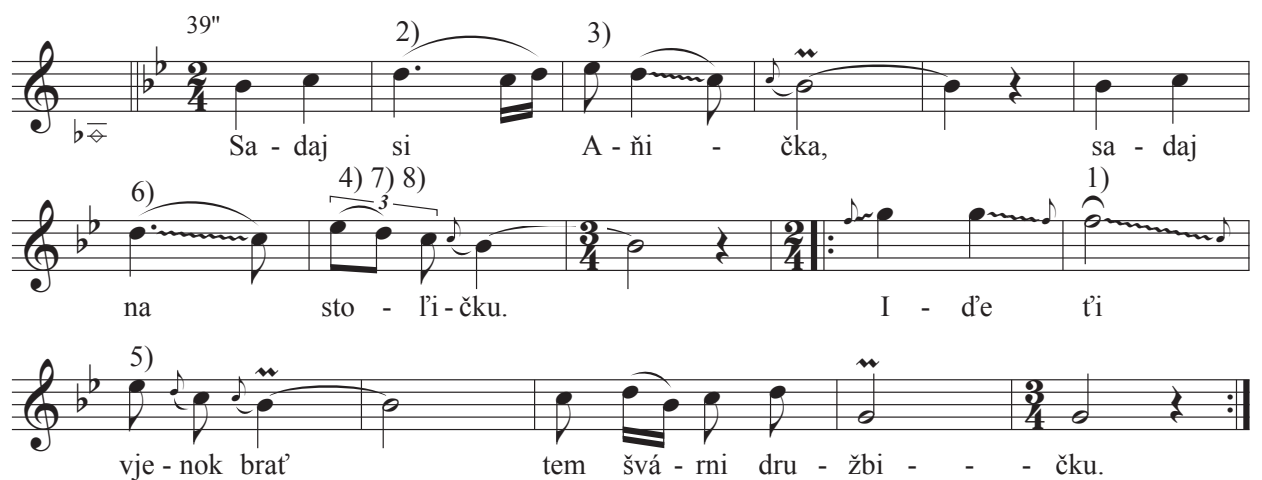
1) 2. sfa pred op.
2) 3. sfa
3) 4. sfa
4) 4. sfa

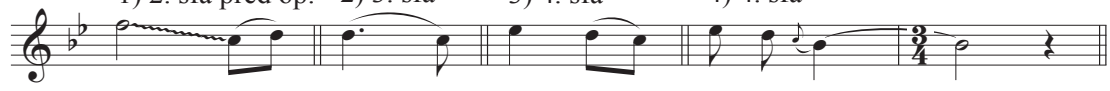

5) 4. sfa, 5. sfa

6) $5 . \mathrm{sfa}$

7) $5 . \mathrm{sfa}$

8) 6. sfa

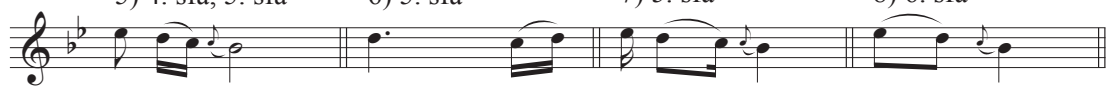

1. Sadaj si Aňička, sadaj na stoličku.

/: Ide ti vjenok brat'

tem švárni družbičku. :/

2. Ked' ti ho bud'e brat', móžeš si zaplakat,, /: móžeš si zaplakat', alebo sa zasmjat. :/

3. Na pazovskom moste gombálija rastie.

/: Polievajte djovke, nak sa vám ňevischňe. :/
4. Ja ráno čas staňem, zalievat' ju bud'em. /: Ked' sa rozel'eňie, vidávat' sa bud'em. :/

5. Vidáva, vidávat', lem ňi odvidávat'. /: Ňije to Bože mój, chl'eba požičiavat'. :/

6. Ked'sa chlieb požičia tem sa misí vrátit, /: al’e tem mój vidaj viac sa ňenavráti: :/ 


\section{Príklad 31}

Uspávanka, spev: Mária Hrehorová (nar. 1950), zápis: Kristina Lomen, október 2018, Stará Pazova
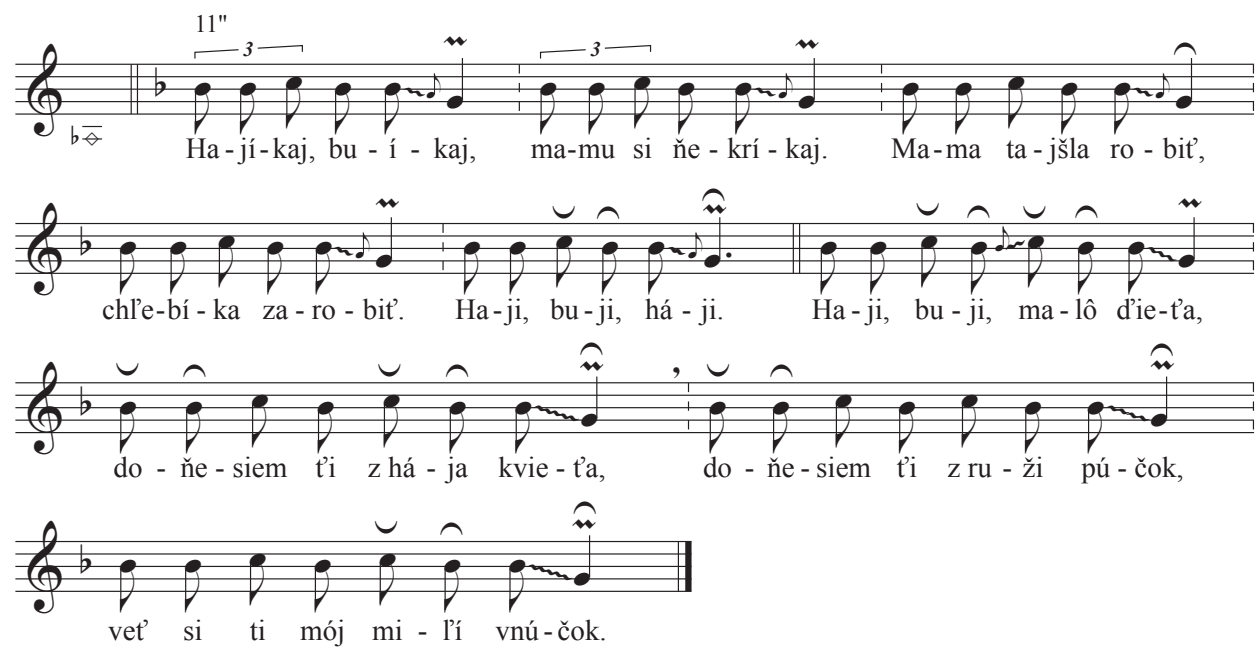

Hajíkaj, buíkaj, mamu si ňekríkaj.

Mama tajšla robit, chlebíka zarobit.

Haji, buji, háji.

Haji, buji malô diet’a,

doňesiem ti z hája kviet’a,

doňesiem tỉ z ruži púčok,

vet’ si ti mój milí vnúčok.

\section{Príklad 32}

Svadobná pieseň, spev: Ján Filip (nar. 1934), zápis: Kristina Lomen, apríl 2014, Stará Pazova
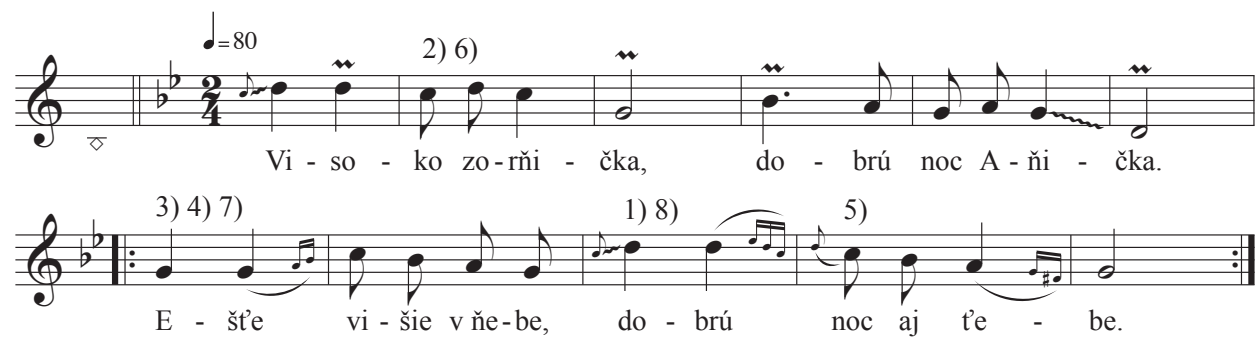
1) 1. sfa pred op. 2) 2. sfa
3) 2. sfa pred op.
4) 2. sfa pri op.,
5) 2. sfa, 3. sfa

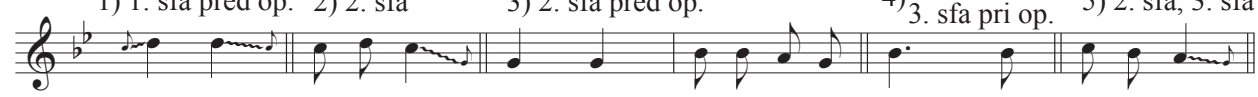

6) 3. sfa 7) 3. sfa pred op. 8) 3. sfa pri op.

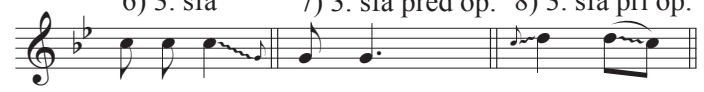


1. /: Visoko zorňička, dobrú noc Aňička. :/

/: Ešte višie ňebe,

dobrú noc aj tebe. :/

2. I: Dobrú noc, dobrú noc,

ale ňi každímu, :/

/: l’em tomu djovčatu,

čo ja chodím k ňemu. :/

3. /: Chodievau milí $\mathrm{k}$ nám

od jari do jari, :/

/: ňigda ňepoviedau

ostávajte zdraví. :/

\section{Príklad 33}

Lúbostná pieseň, spev: Anna Šagová (nar. 1980), zápis: Kristina Lomen, apríl 2014, Stará Pazova
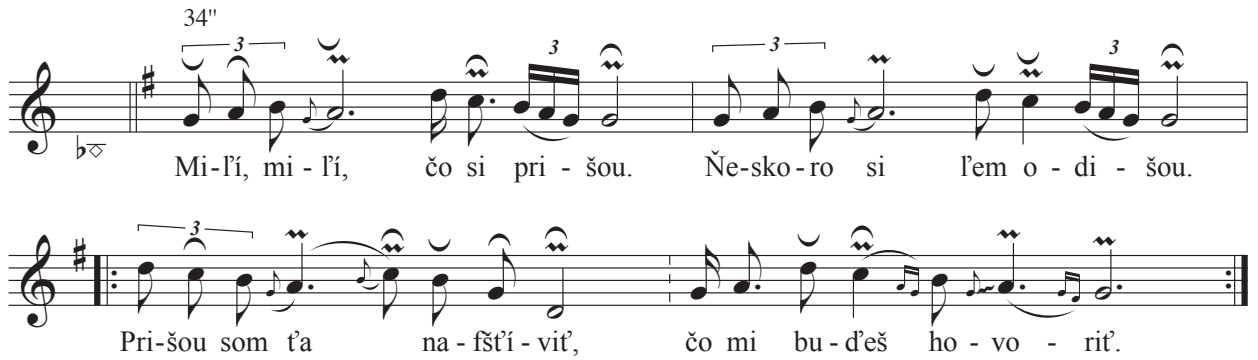

1. Milí, milí, čo si prišou, ňeskoro si l'em odišou.

/: Prišou som ta nafštívit', čo mi bud'eš hovorit'. :/

2. Prišou som sa ti spítati, či sa bud’eš vidávati.

/: A ja sa vidat’ móžem,

lem za tebe ňepójd’em. :/

3. Hladaj si ti takie paňi čo sa hrajú s tisícami.

/: L’em si ti milí rozváž,

kelko takích djovok mášs. :/

4. Makar bou aj bez košeli, nak je šuhaj mojéj vóli. /: S tím ja bud'em spokojná, aj nás Pám Boh požehná. :/ 


\section{Príklad 34}

Vojenská pieseň, spev: Pavel Leštan (1964 - 2015), zápis: Kristina Lomen, apríl 2014, Stará Pazova
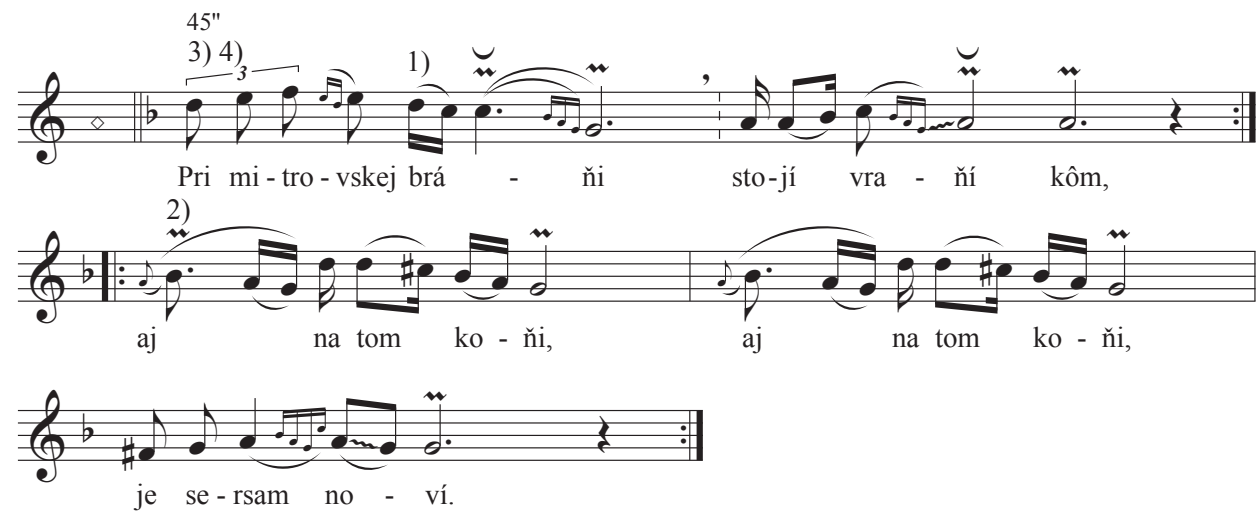
1) 2. sfa
2) 2. sfa, 3. sfa
3) 3. sfa pred op.

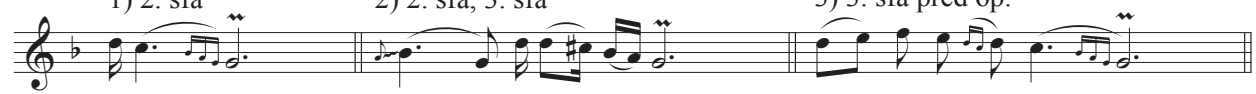

4) 3. sfa pri op.

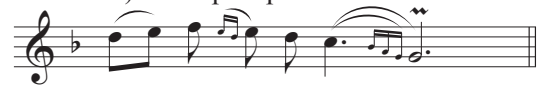

1. /: Pri mitrovskej bráňi

stojí vraňí kôm, :/

aj na tom koňi,

aj na tom koňi

je sersam noví.

2. /: Ešte na tom koňi

visí šablička, :/

čo sa bó bráňit',

čo sa bó bráňit’

moja hlavička.

3. /: Otec je orbster a sim gemajner. :/

Kto šablu nosí, tem zahinút misí ako oficier. 


\section{Príklad 35}

Lúbostná pieseň, spev: Spevácka skupina pazovských žien, zápis: Kristina Lomen, apríl 2014, Stará Pazova

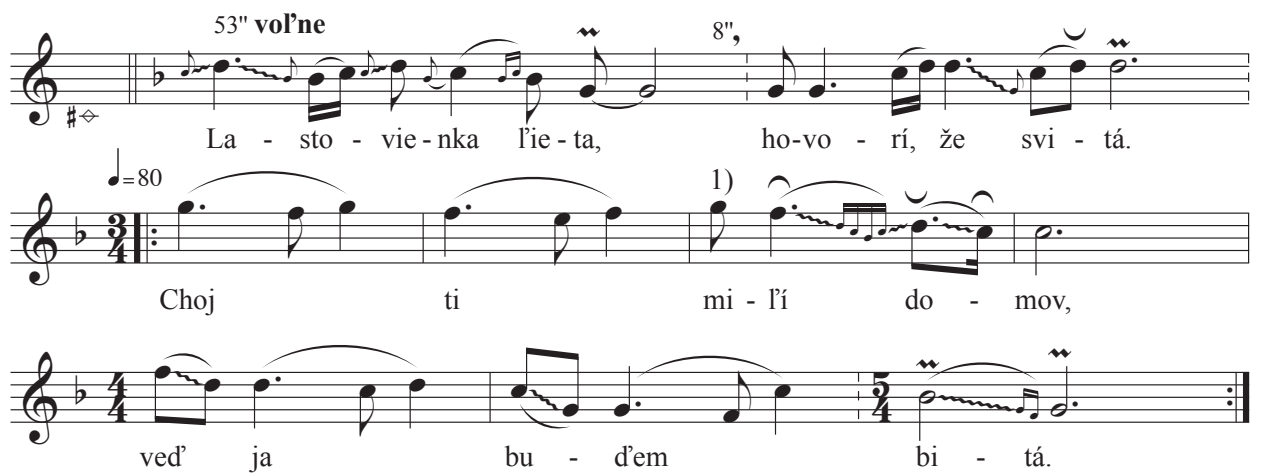

1) 2. $-4 . \mathrm{sfa}$

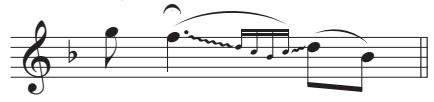

1. Lastovienka lieta, hovorí, že svitá.

/: Choj ti milí domov, ved' ja bud’em bitá. :/

2. Ved' ja bud’em bitá od mojej mamički, /: že som ňenažala zel’eňej trávički. :/

3. A ja bud'em bití od mojho tatíčka, I: že som ňenapojiv vraňího koňíčka. :/

4. Ešte bud’em bití aj od mojho dedu, /: že ma každvo ráno opilího vedú. :/ 


\section{Príklad 36}

Lúbostná pieseň, spev: Vladimír Žolnaj (nar. 1964), apríl 2014, Stará Pazova, zápis: Kristina Lomen
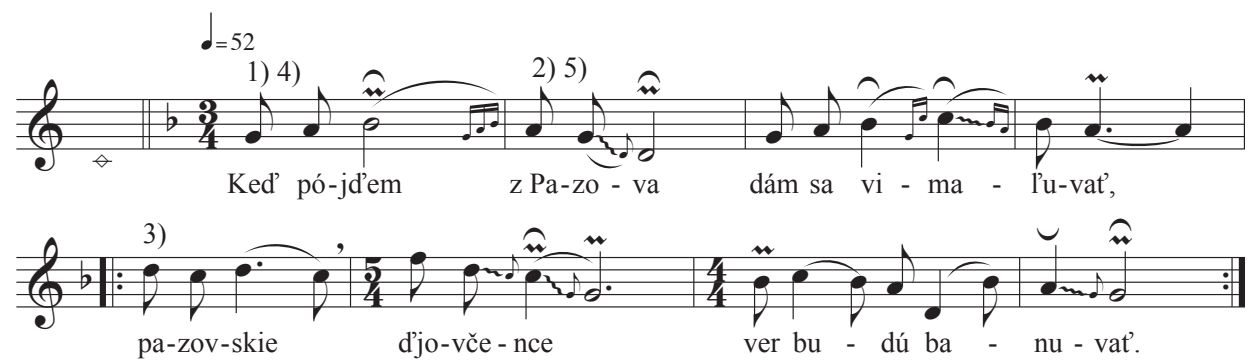
1) 2. sfa
2) 2. sfa, 3. sfa., 5. sfa
3) 2. sfa, 5. sfa pri op.,
4) 3. $-6 . \mathrm{sfa}$

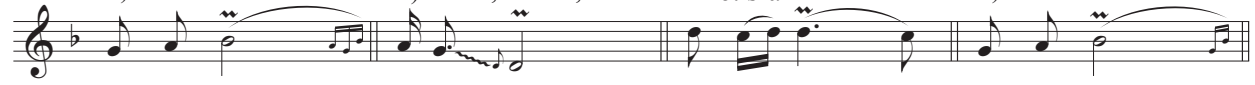

5) 6. sfa

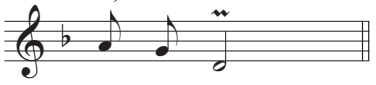

1. Ked' pójd’em z Pazova

dám sa vimaluvat,

/: pazovskie djovčence

ver budú banuvat. :/

2. Banuj djovča, banuj, máš za kím banuvat, /: mala si frajera, ňebud'eš ho viac mat'. :/

3. Mala si ho mala sedmorakej krási, /: mav vom čierňe oči, štebotavje reči. :/

4. Očká sa mu smejú, l'íčka červeňejú, /: a spod jeho srca slzi sa mu lejú. :/

5. Ňelejú, ňel'ejú, lem kropajom padajú, /: na marvam kameňi jamke vibíjajú. :/

6. Marvam kemem, marvam, marvanova skala, /: šecka naša láska pod tebou ostála :/ 


\section{Príklad 37}

Vojenská pieseň, spev: Ján Pecník (1930 - 2020), zápis: Kristina Lomen, apríl 2014, Stará Pazova
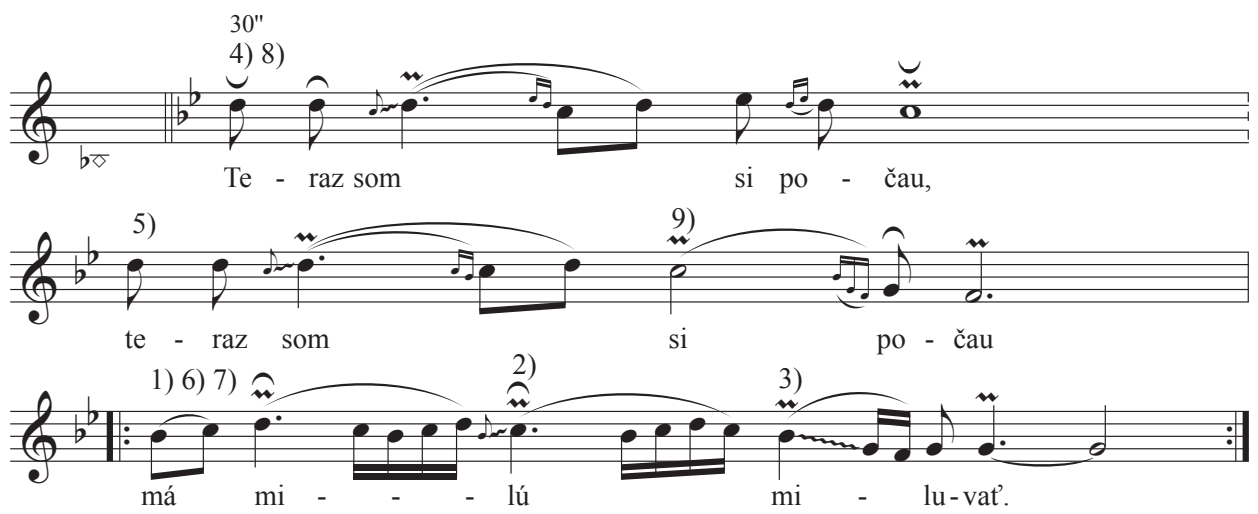

1) 2. sfa

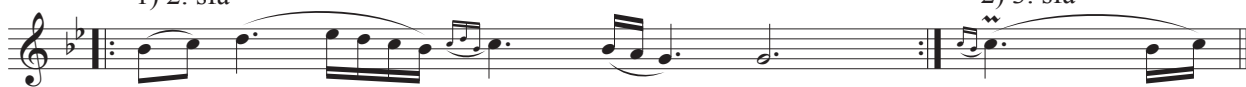

3) 3. sfa

4) 4. sfa

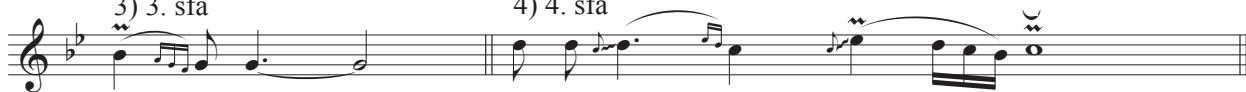
5) 4. sfa
6) 4. sfa, 6. sfa
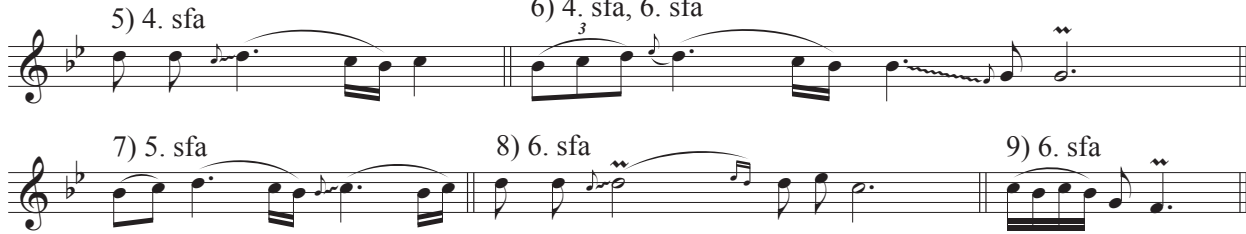

1. /: Teraz som si počau :/

/: má milú miluvat. :/

2. /: Lístočok mi prišou, :/

/: že mám narukuvat'. :/

3. /: Ked' som narukuvau :/

/: ofec na mňa volau. :/

4. /: Sinu mój, Bože mój :/

/: taško som ta chovau. :/

5. /: Ťaško som ta chovau :/

/: ako zem tulipám. :/

6. /: Aj ti sa prechodíš :/

/: po vojňe ako pám. :/ 


\section{Príklad 38}

Sociálna pieseň, spev: Anna Šagová (nar. 1978), zápis: Kristina Lomen, apríl 2014, Stará Pazova
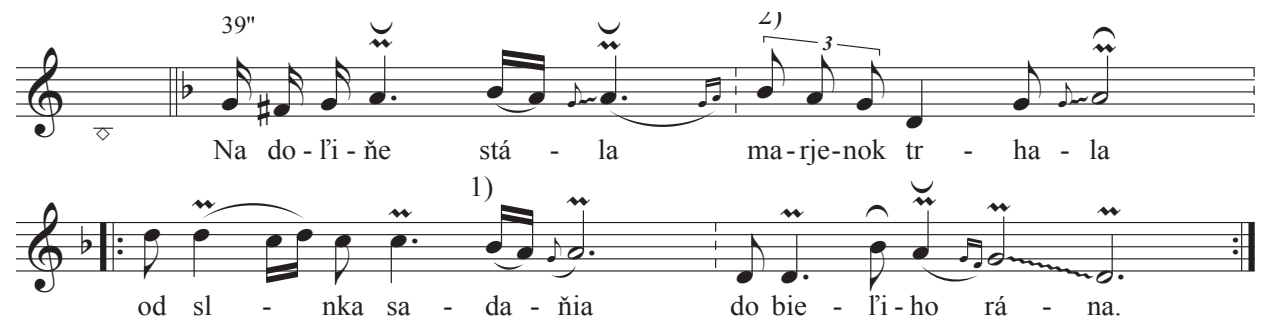
1) $2 .-4 . \mathrm{sfa}$
2) 3. sfa, 4. sfa

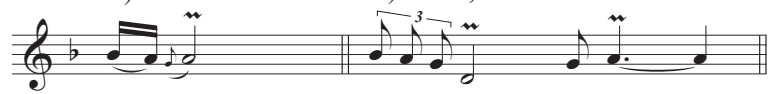

1. Na doliňe stála, marjenok trhala /: od slnka sadaňia do bieliho rána. :/

2. Uviaž milí koňa vedla nážho plota /: nag ludia ňevravia, že som ja sirota. :/

3. Ked'bi som ja bola djovčina bohatá /: nosievala bi som korunku zo zlata. :/

4. Ale nosím vjenok zo šípovej ruži /: tak ako čo nosia chudobňie siroti. :/ 


\section{Príklad 39}

Lúbostná pieseň, spev: Ján Pecník (1930 - 2020), zápis: Kristina Lomen, apríl 2014, Stará Pazova

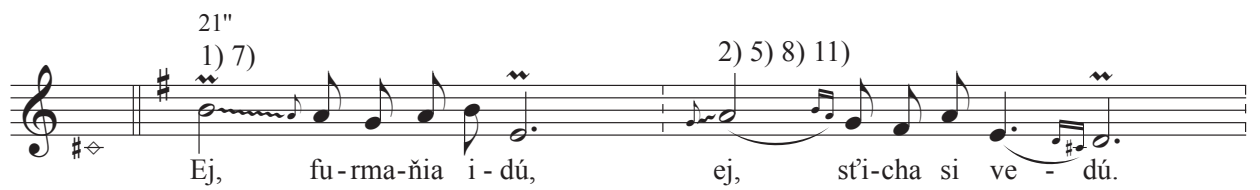

3) 6) 9) 12)

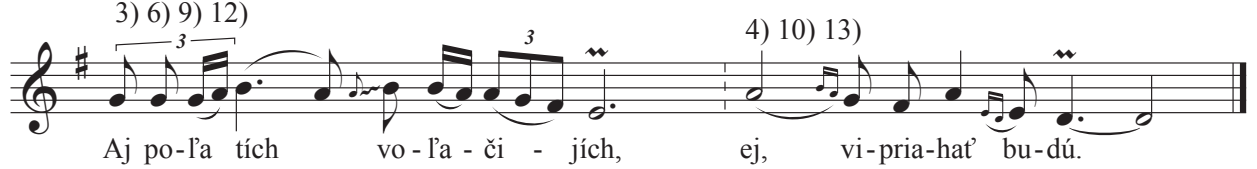

$\begin{array}{lll}\text { 1) } 2 \mathrm{sfa}, 3 . \mathrm{sfa}, 6 . \mathrm{sfa} & \text { 2) } 2 \text {. sfa, 3. sfa } & \text { 3) } 2 \text {. sfa }\end{array}$

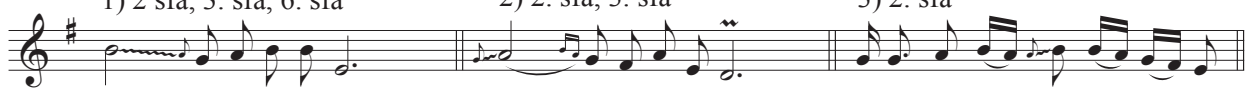

4) 2. sfa, 3. sfa

5) 3. sfa

6) 3. sfa

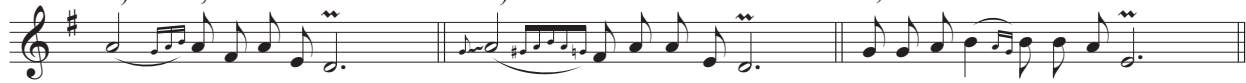

7) 5. sfa

8) 5. sfa

9) 5. sfa

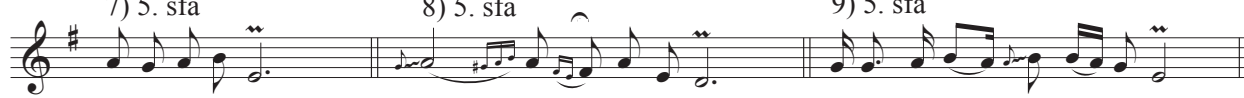

$\begin{array}{ll}10) 5 . \mathrm{sfa} & \text { 11) } 6 . \mathrm{sfa}\end{array}$

12) 6. sfa

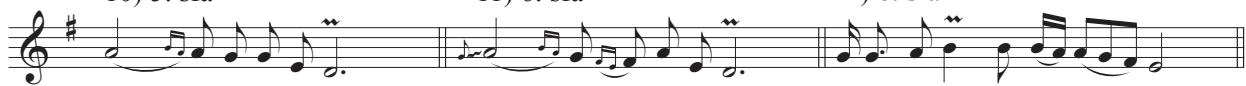

13) 6. sfa

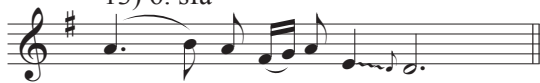

1. Ej, furmaňia idú, ej, sticha si vedú.

Aj pola tích volačijích, ej, vipriahat budú.

2. Ej, akí je to pám, ej, tem uhorskí král.

Kcev vom djovča oklamat', ej, a sklamav sa sám.

3. Ej, skríkov na koňe, ej, či ja mám moje. Obozri sa moja milá, ej, šecko je tvoje.
4. Ej, šecko je tvoje, ej, to šíre pole.

5. Ej, šecko je moje, ej, tuto na voze, lem som si je pozabudla, ej, vjenok na stole.

6. Ej, vjenok zeleňi, $\mathrm{z}$ rozmarínu upleteňí, čo koštuvau tristo zlatích, ej, aj dva dukáti. 


\section{Príklad 40}

Lúbostná pieseň, spev: Pavel Leštan (1964 - 2015), zápis: Kristina Lomen, jún 2014, Stará Pazova
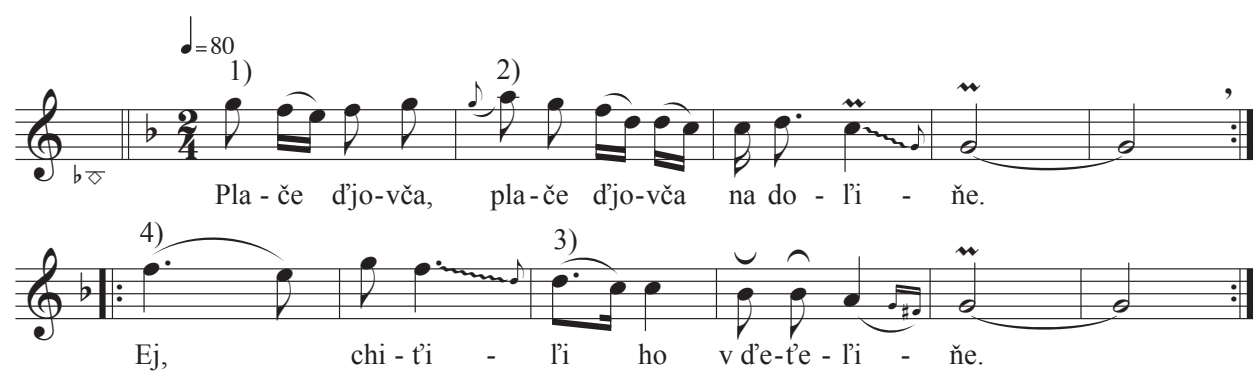
1) 2. sfa., 3. sfa,
2) 2. -6. sfa
3) 2. sfa pred op.
4) 2. sfa pri op., 5. sfa

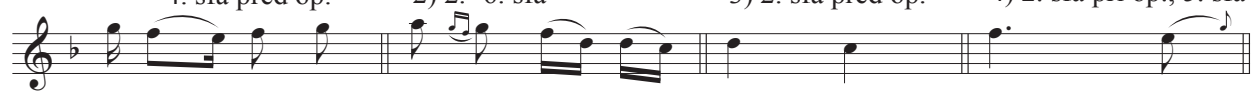

1. /: Plače djovča, plače djovča na doliňe. :/ /: Ej, chitili ho v deteleliňe. :/

2. /: Kebi ved’ev, kebi ved’ev, čo mu zali, :/ /: ej, bielì ručňík višiváňí. :/

3. /: Kebi ved’ev, kebi ved’ev, že bez vini, /: ej, zapáliv bi dve dedini. :/

4. /: Prvú Pazov, prvú Pazov, potom Vojku, :/ /: ej, za tú našu peknú djóvku. :/

5. /: Pazov horí, Pazov horí, Vojka ňechce, :/ /: ej, chitili ma pri ňeveste. :/

6. /: Pri ňeveste, pri ňeveste pri takovej, ej, pri Aňički krčmárovej. :/ 


\section{Príklad 41}

Pieseň na svadbe, spev: Spevácka skupina pazovských žien, zápis: Kristina Lomen, jún 2014, Stará Pazova
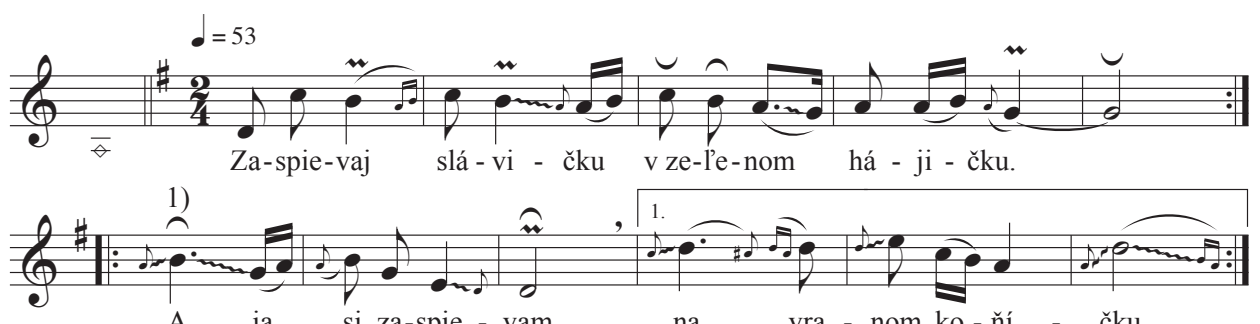

A ja si za-spie - vam na vra - nom ko - ňí - čku

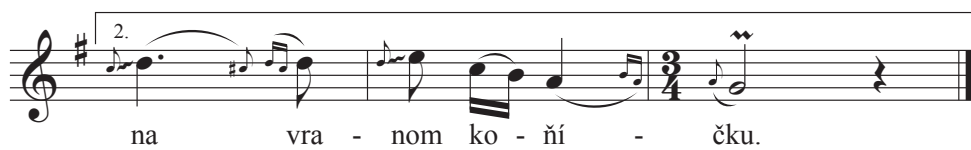

1) 1. sfa pri op. -7 . sfa

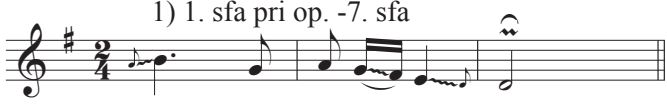

1. /: Zaspievaj slávičku v zel’enom hájičku. :/

/: A ja si zaspievam na vranom koňičku. :/

2. I: Šecia ludỉa vravia, že je vojna lem špás, :/

/: že sa ja navrátim o malí, krátki čas. :/

3. I: Ja som sa navrátiv šecok dorúbaňí, :/

/: že ma rodičovia moji ňepoznali. :/

4. /: Rodičovia moji preboha vás prosím, :/

/: ňebráňte mi ziati, čo ja f srci nosím. :/

5. /: Ja f srdiečku nosím chudobnú djovčinu. :/

Taká je chudobná, čo ňičoho ňemá,

lem tú jej poctivost', čo si zachovala.

6. I: Poctivost', poctivost' vo svete panuje. :/

/: kerá ju djovka má, nak si ju šanuje. :/

7. /: A ja som si a ja moju šanuvala, :/

/: fčera pred oltárom sa mi rozviazala. :/ 


\section{Príklad 42}

Balada, spev: Vladimír Žolnaj (nar. 1964), zápis: Kristina Lomen, apríl 2014, Stará Pazova
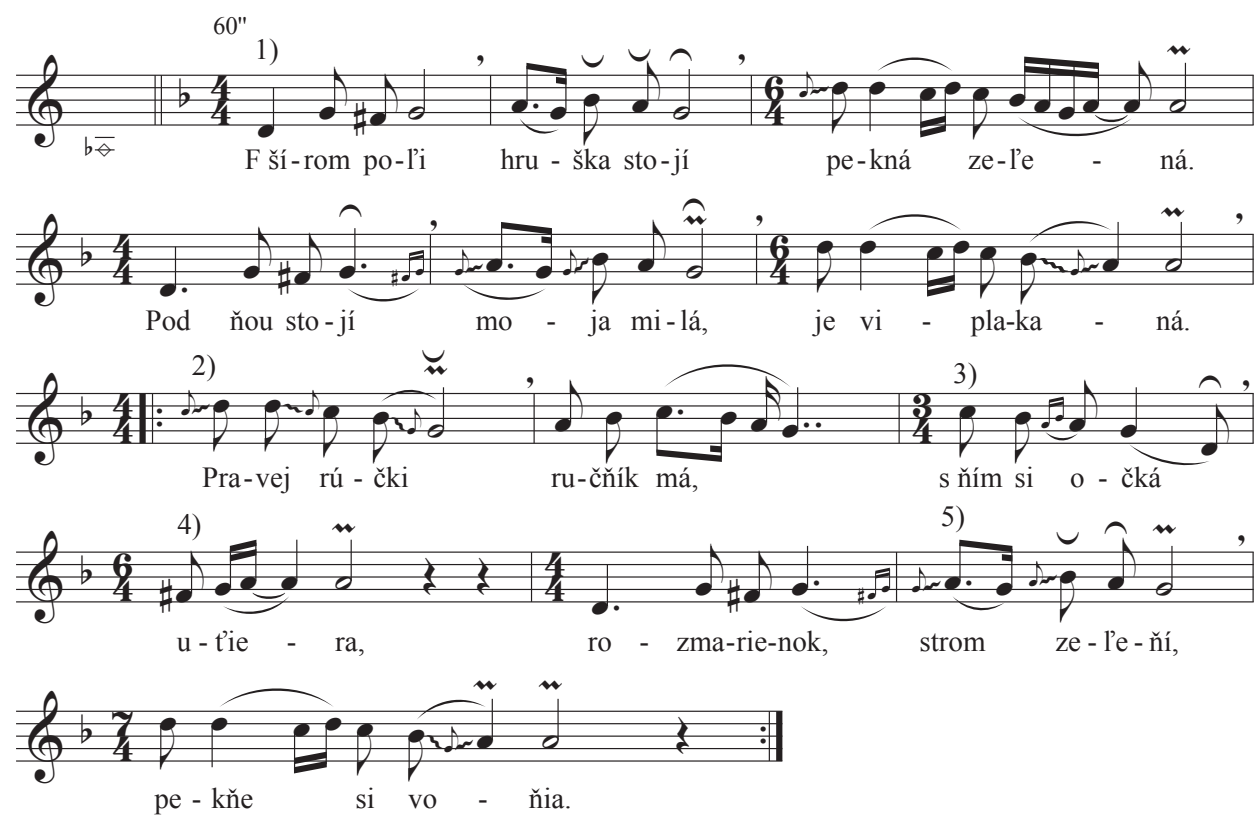
1) 2. sfa
2) 2. sfa
3) 2. sfa, 2. sfa pri op.
4) 2. sfa

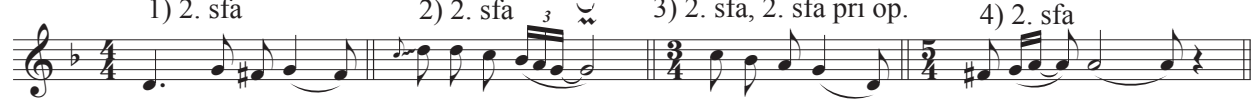

5) 2. sfa pri op.

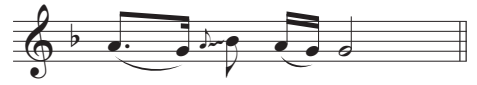

1. F šírom poli hruška stojí pekná zelená.

Pod ňou stojí moja milá

je viplakaná.

/: V pravej rúčki ručňík má s ňím si očká utiera.

Rozmarienok, strom zeleňí, pekňe si voňia. :/
2. Ňemislev som tejto noci, že vojak bud’em, že na svojom pleci pušku, nosievat' bud'em.

Aj na bôčku šablička plačú ołec, mamička, že stratili svojho sina $\mathrm{v}$ dvaciatom rôčku. Ňeplačú tak otec, mat’ ako plače frajerka, že jej bud'e nocúvávat' prázna postielka. 


\section{Príklad 43}

Lúbostná pieseň, spev: Pavel Leštan (1964 - 2015), zápis: Kristina Lomen, apríl 2014, Stará Pazova
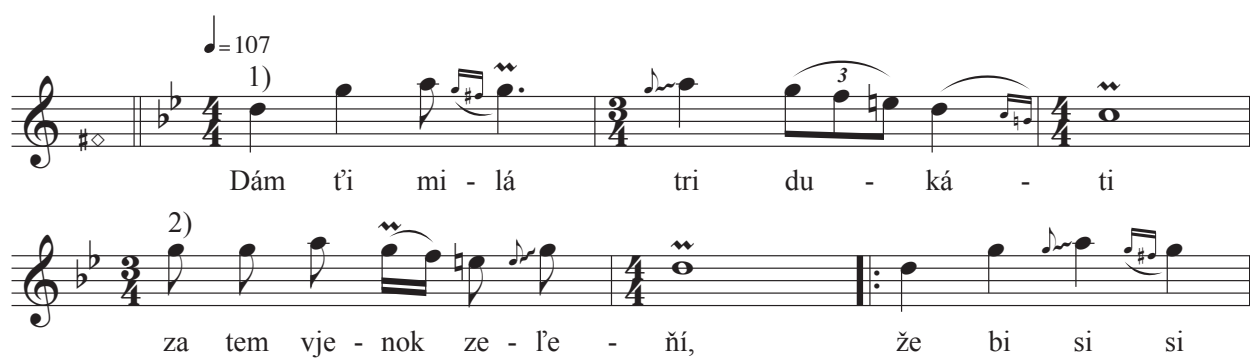

3)

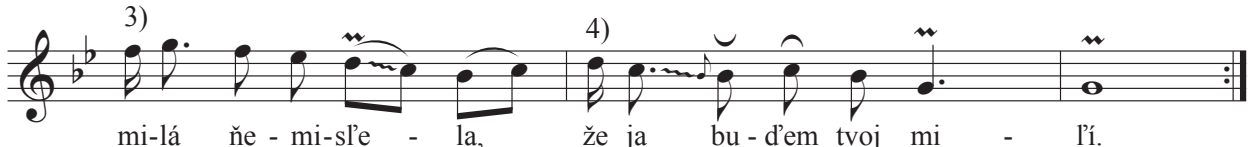
1) 2.-4. sfa
2) 2. sfa, 3. sfa
3) 2. sfa
4) $2 .-4 . \mathrm{sfa}$

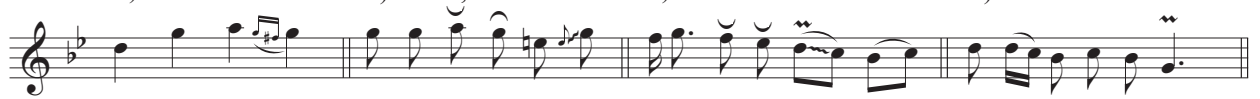

1. Dám ti milá tri dukáti za tem vjenok zel’eňí, /: že bi si si milá ňemislela, že ja bud’em tvoj milí. :/

2. Osedlám si ja koňíčka, aj vojuvat' ja pójd’em, /: aj ke sa ja z vojňe domov vrátim, potom sa žeňit bud’em. :/

3. Ke ti pójdeš na tú vojnu,

a ja pójdem za tebou,

/: predstavím sa pred pána majora,

aj žaluvat' sa im bóm. :/

4. Žaluj pánu, žaluj králu, žaluj sa ti komu chceš, /: žaluj sa ti celej regimente, preca moja ňebud’eš. :/ 


\section{Príklad 44}

Zbojnícka pieseň, spev: Pavel Leštan (1964 - 2015), zápis: Kristina Lomen, apríl 2014, Stará Pazova

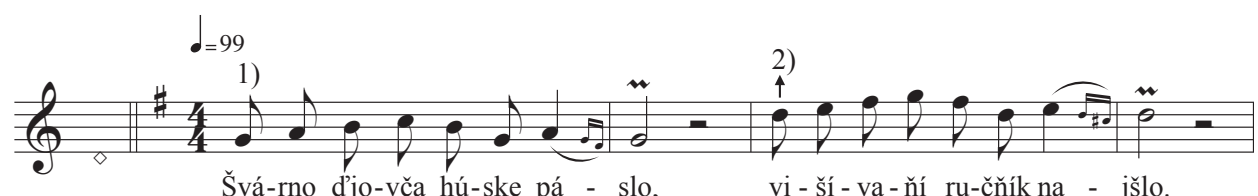

3)

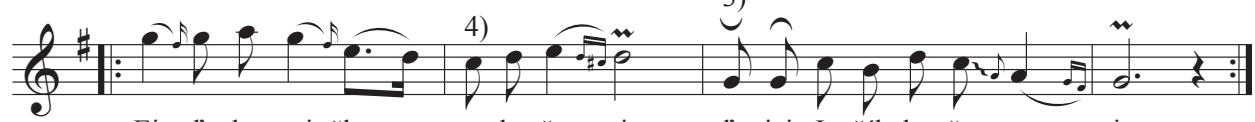

Ej, d'e ho naj-šlo, nagho ňe - sie, d'e jej Ja-ňík ko-ňe pa - sie.
1) 2.-4. sfa
2) 2.-4. sfa
3) 2. sfa
4) 4. sfa

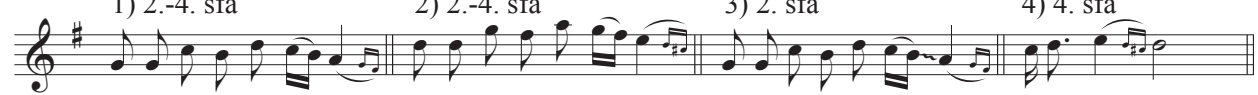

1. Švárno djovča húske páslo, višívaňí ručňík najšlo.

/: Ej, de ho najšlo, nag ho ňesie,

d’e jej Jaňík koňe pasie. :/

2. Pasie ich vom na doliňe,

na tej drobňej deteleliňe,

/: Ej, paste sa vi, l'ebo lešte,

ja milujem djovča ešte. :/

3. Jaňík, Jaňík, šíri zbojňík, vieš do hore každí choňík.

/: Ej, ňi lem choňík, aj cestičke,

sked’e chodia ňevestičke. :/

4. Večer tájd'eš, ráno príd’eš, ňigda mi ňišt ňedoňesieš. /: Ej, l’em košelu zarosenú,

aj šabličku skrvavenú. :/ 


\section{Príklad 45}

Lúbostná pieseň (na záletoch), spev: Pavel Leštan (1964 - 2015), zápis: Kristina Lomen, apríl 2014, Stará Pazova
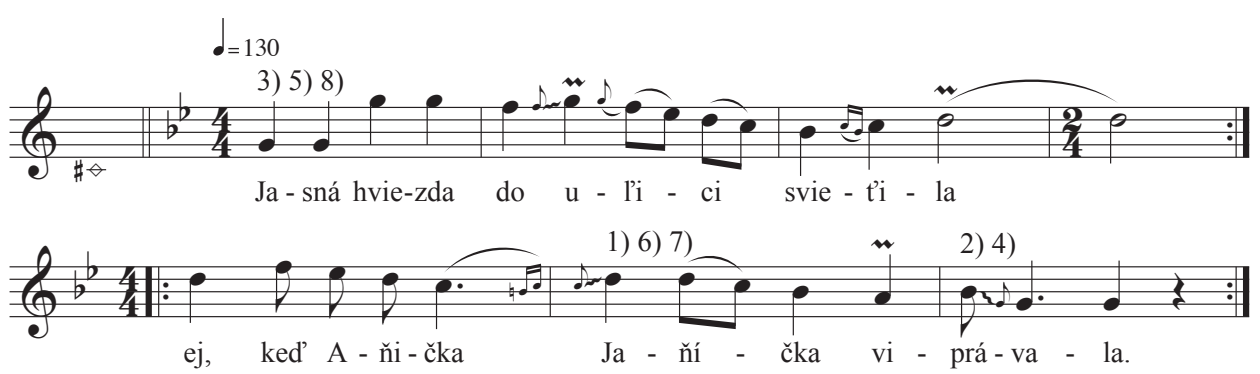

1) 1. sfa pri op.

2) 2. sfa pri op.

3) 3. sfa

4) $3 .-5 . \mathrm{sfa}$

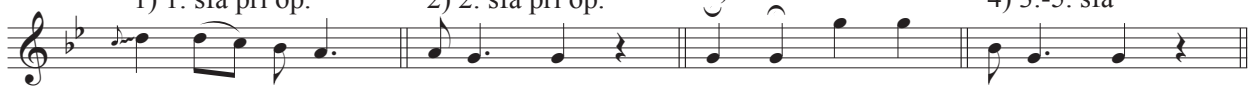

5) 4. sfa

6) 4. sfa pred op., 5. sfa

7) 4. sfa pri op.

8) $5 . \mathrm{sfa}$

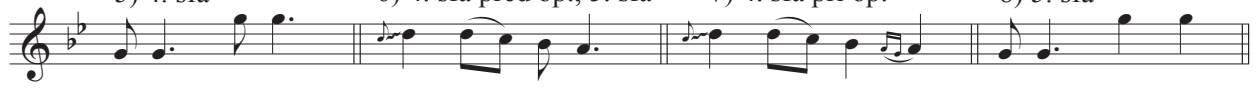

1. /: Jasná hviezda do ulici svietila, :/

/: ej, ked’ Aňička Jaňíčka viprávala. :/

2. /: Natiahov si vom klobúčok na oči, :/

/: ej, aj misl'ev si, že id’e o pou noci. :/

3. I: O pou noci, o dvanáctej hodiňe, :/

/: ej, a mamka ho hladala u rodiňe. :/

4. /: Jaj, mámilá, mi zme dvaja zaspali, :/

/: ej, ke som prišou naši bolì už stáli. :/

5. /: Vravím mamki, že som ja spav f koňici, :/

/: ej, klameš betár, teraz id’eš z ulíci. :/ 


\section{Príklad 46}

Lúbostná pieseň, spev: Vladimír Žolnaj (nar. 1964), zápis: Kristina Lomen, apríl 2014, Stará Pazova
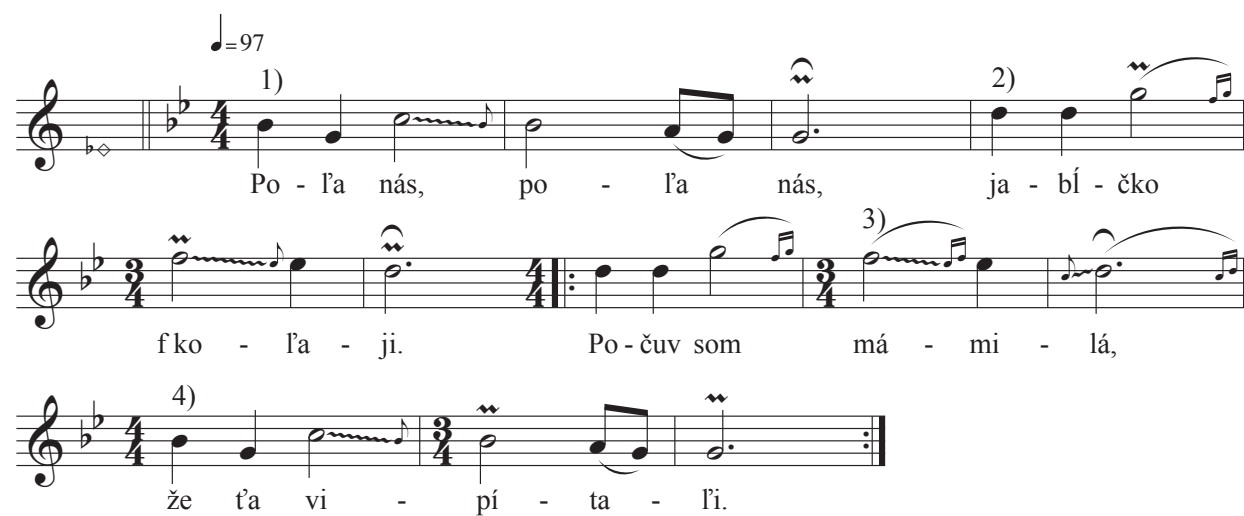
1) 2. sfa, 3. sfa
2) 2. sfa
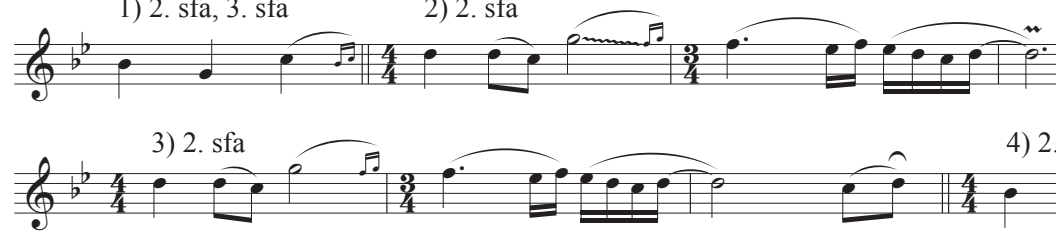

4) 2. sfa

1. Pola nás, pol’a nás, jabíčko f kolaji.

/: Počuv som má milá, že ta vipítali. :/

2. Račej bi som počuv, že si mi zomrela, /: ako čo som počuv, že si sa vidala. :/

3. Ja som sa vidala, že mi bud'e l'epšie. /: Spod mojho srdiečka krv potokom tečje. :/

4. Ňetečie potôčkom, ale aj Dunajom, /: ale aj Dunajom za švárňim šuhajom. :/ 


\section{Príklad 47}

Balada, spev: Ján Pecník (1930 - 2020), zápis: Kristina Lomen, jún 2014, Stará Pazova

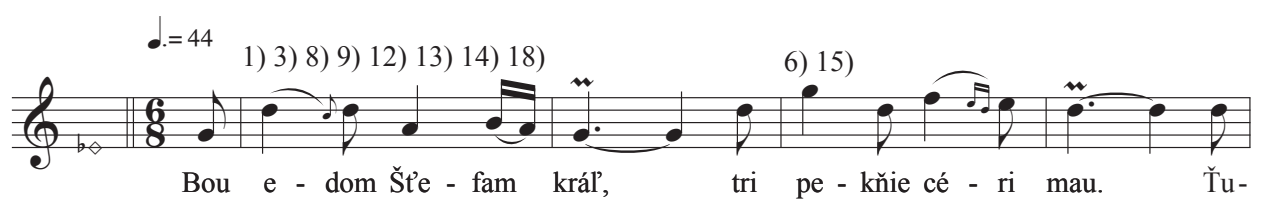

2) 4) 10) 16)

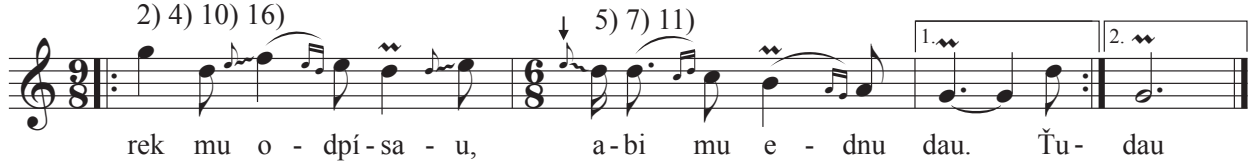

1) 2. sfa, $5 . \mathrm{sfa}$

2) 2. sfa, 4. sfa

3) 3. sfa

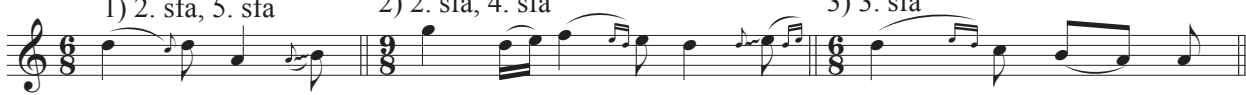
4) 4. -6. sfa, 10. sfa, 13. sfa
5) 4. sfa, 9. sfa
6) 5. -10. sfa, 15. sfa
7) 5. sfa, 6. sfa,

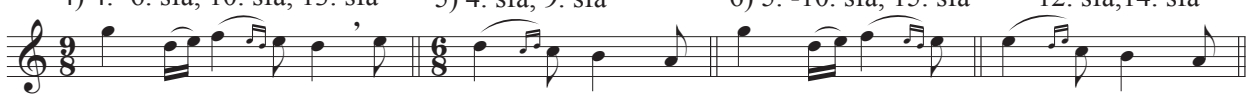
8) 6. sfa
9) 7. sfa, 13. sfa
10) 7. sfa, 9. sfa
11) 7. sfa, 8. sfa

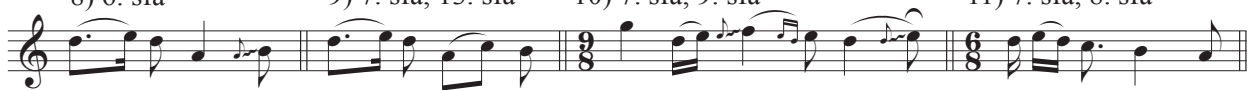

12) $8 . \mathrm{sfa}, 14 . \mathrm{sfa}$

13) 9. sfa, 11. sfa

14) 10. sfa, 15. sfa

15) 11.-13. sfa

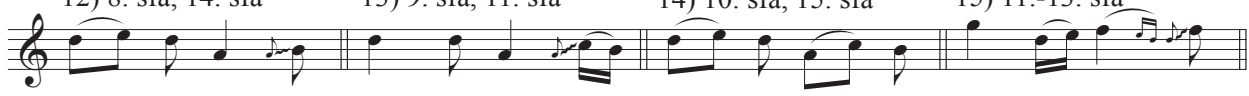

16) 11. sfa, 12. sfa

17) 11. sfa

18) 12. sfa

19) 12. sfa, 13. sfa

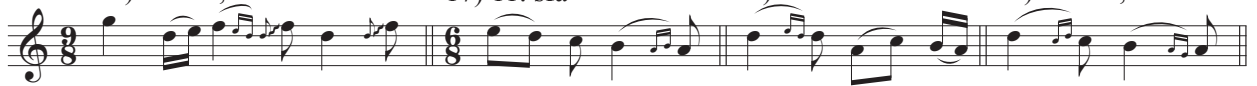

1. Bou edom Štefam král, tri pekňie céri mau.

/: Ťurek mu odpísaou, abi mu ednu dau. :/

2. Aj ked' prišou domou, sadou si vom za stóu, jeho bielu hlávku zalomiv si na stóu.

3. Céra sa spituje: apovka čo vám je? Či vás hlávka bolí, a či srce morí?

4. Hlávka ma ňebolí, srce ma ňemorí, /: ale som ta vidau Ťurku pohanovi. :/
5. Céra pod jej oknom, ach, apovka milí, ach, apovka milí, čierna sa zem valí. Čierna sa zem valí. pred našíma bráňi.

6. Ňije to čierna zem, ale sa to Ťurci, ale sa to Turci, tvoji svadobňíci.

7. Prví raz strelilili, na ňu zavolali, deže je tá panna, kerá má ít s nami. 
8. Počkajte, pričkajte, vi prvoratári, nak si ja roščešem moje dlhé vlasi.

9. Také boli dlhie, zemi sa tahali, také boli žlté, slnka sa ňeznali.

10. Druhí raz strelilili, na ňu zavolalì, deže je tá panna, kerá má ít s nami.

11. Počkajte, pričkajte, vi druhoratári, nak sa odoberiem od oca, materi.
12. Ďakujem vám apo za zlô vidávaňia, /: jaj, aj vám mamička za dobruô chovaňia. :/

13. Tretí raz streliili, na ňu zavolali, či si sa sprémila, už raz mladá paňi.

14. Počkajte, pričkajte, vi tretoratári, nak sa ja napijem tej dunajskej vodi.

15. Ednou rúčkou pila, druhou sa topila, ach, úbohuô djovča Turka sa sprostila.

\section{Príklad 48}

Balada, spev: Ján Pecník (1930 - 2020), zápis: Kristina Lomen, jún 2014, Stará Pazova
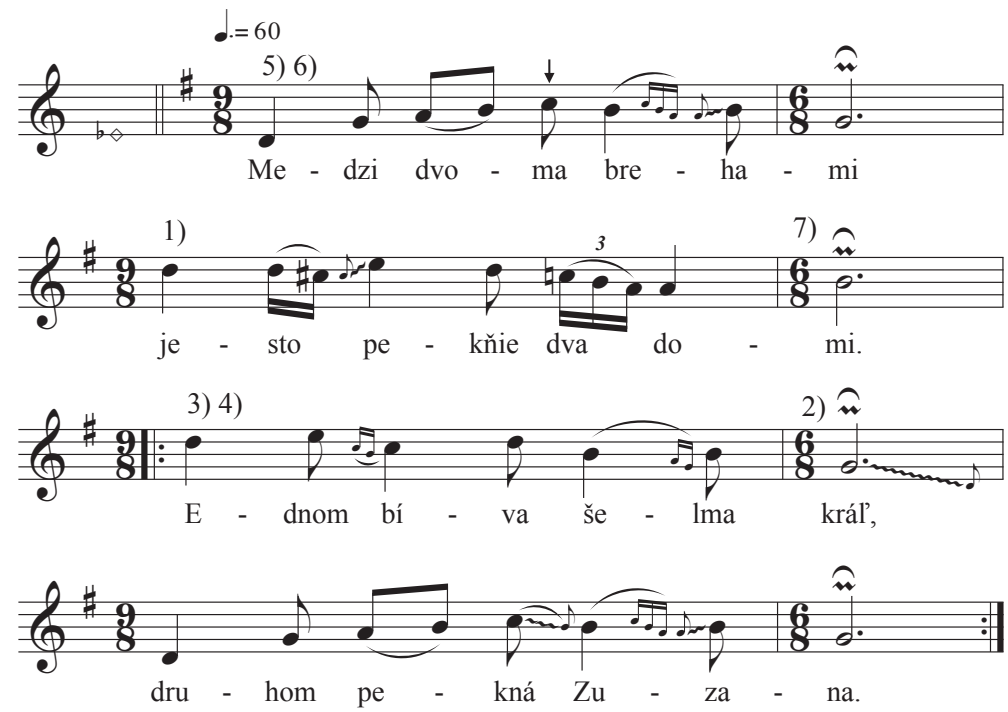

1) 2. sfa, 6.-8. sfa

2) 2. sfa

3) 2. sfa pri op.

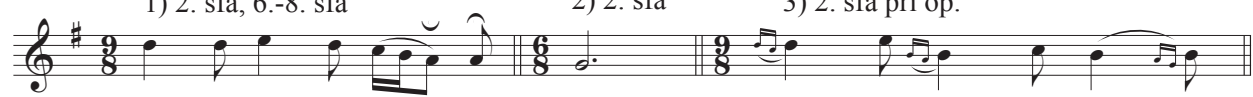

4) 3. sfa, 6. sfa, 7. sfa 5) 4. sfa, 5. sfa

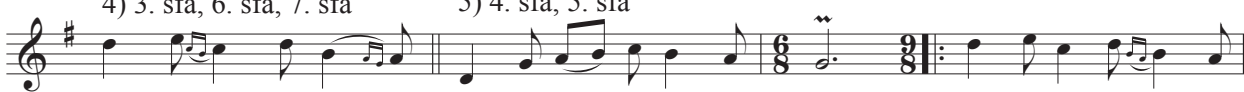



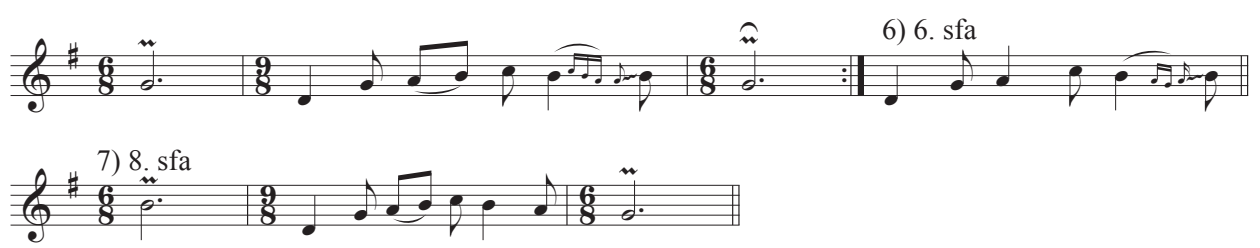

1. Medzi dvoma brehami jesto pekňie dva domi. /: Ednom bíva šelma král, druhom pekná Zuzana. :/

2. Naučiv sa šelma král chodit pekňej Zuzaňe. /: Tri ráz kláštor obišou, dvere ňigd’e ňenajšou. :/

3. Iba jeden obločok, čo pri ňom spí Zuzana. /: Spíš Zuzana, spíš zdravá, bodaj hore ňestála. :/

4. Spíš Zuzana, či čuješ, spíš Zuzana, či čuješ, či ma verňe miluješ.
5. A ja aj spím, aj čujem, /: a ja aj spím, aj čujem ale ta ňemilujem. :/

6. Choj ti šelma, choj domov, bodaj si hlavu vitkol. Choj ti šelma, choj domov, bodaj si hlavu vitkol.

7. Ňeušlo to delako, lem na pole širokuô, šelmovi sa kôm potkou, šelma si hlavu vitkou.

8. Verte ludia pravda je, verte ludia pravda je, čo Zuzana preklaje. 


\section{Príklad 49}

Lúbostná pieseň (na záletoch), spev: Ján Šago (nar. 1979), zápis: Kristina Lomen, jún 2014, Stará Pazova
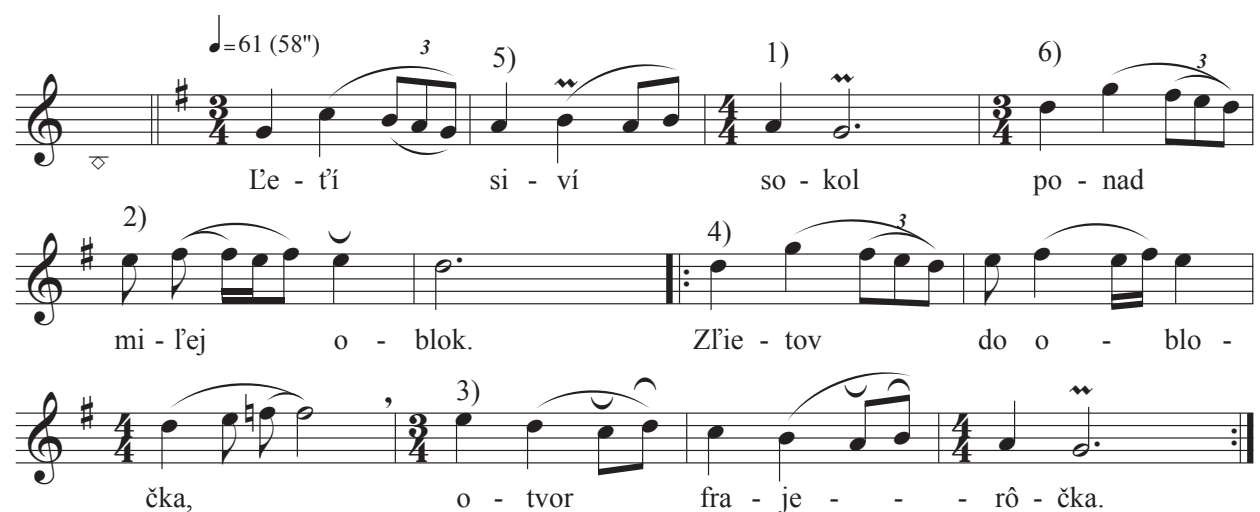
1) 2. sfa
2) 2. sfa
3) 2. sfa pred op

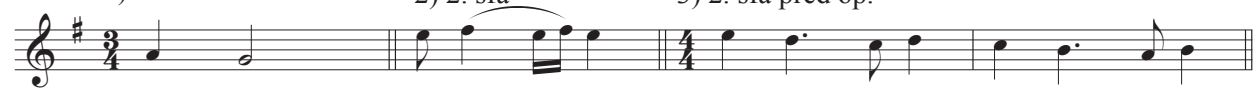

4) 2. sfa pri op

5) $3 . \mathrm{sfa}$

6) 4 . sfa

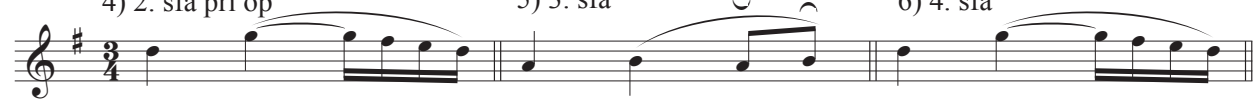

1. Letí siví sokol

ponad milej oblok.

/: Zlietov do obločka,

otvor frajerôčka. :/

2. Ona otvorila

l'em edom obločok.

/: Ťíško zavolala,

pot tanu Jaňíčok. :/

3. Ja tanu ňezíd’em, aňi k vám ňepríd’em,

/: aňi vaše dverce

otvárat' ňebud'em. :/

4. Aňi vaše dverce,

aňi vašu klučku.

/: Dobrú noc ti dávam,

milá na rozlúčku. :/ 


\section{Príklad 50}

Pohrebný plač, spev: Ján Pecník (1930 - 2020), zápis: Kristina Lomen, jún 2014, Stará Pazova
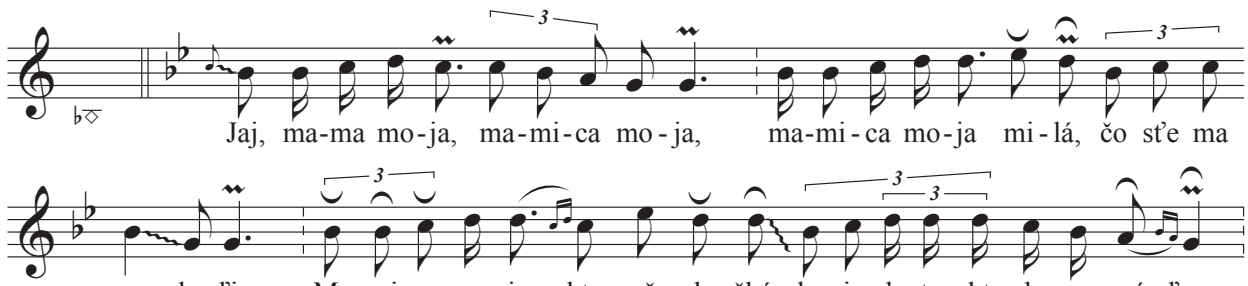

na - ha-l'i. Ma-mi-ca mo-ja kto mňa do-čká, ke ja do to-chto do-mu prí-d'em.
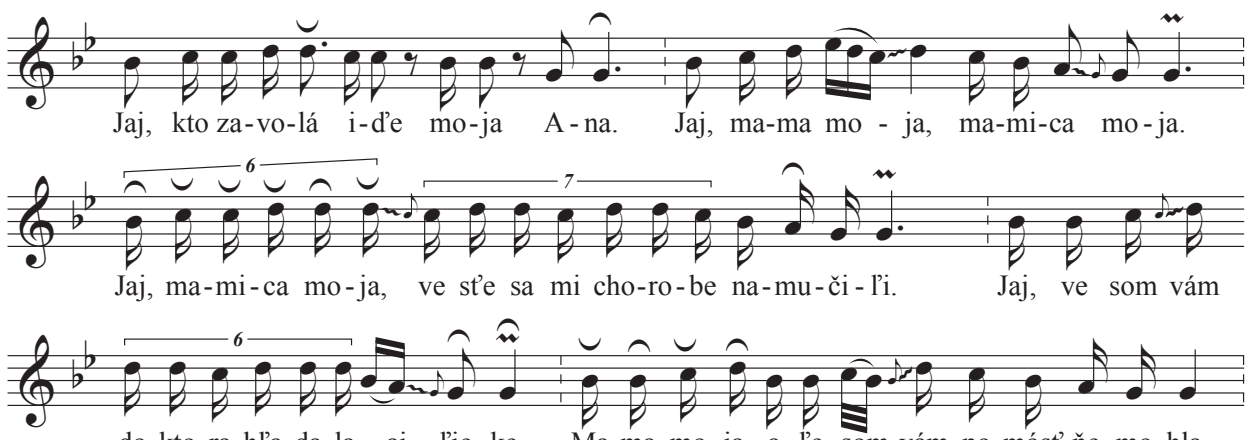

do-kto-ra hl'a-da-la aj l'ie-ke. Ma-ma mo-ja, a-l’e som vám po-móst' ňe-mo-hla.

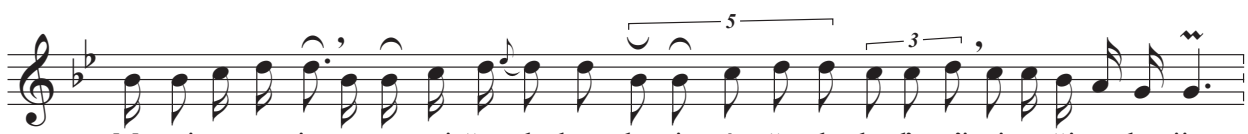

Ma-mi-ca mo-ja, te-raz pri-šou do-ktor, ke-rie vám še-cke bo-l’a-st’i aj ra-ňi za-ho-jiu.
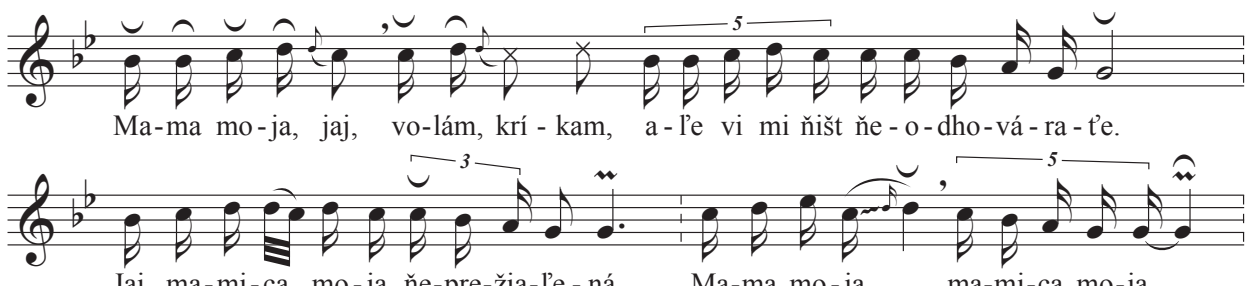

Jaj, ma-mi-ca mo-ja ňe-pre-žia-l’e-ná. Ma-ma mo-ja, ma-mi-ca mo-ja.
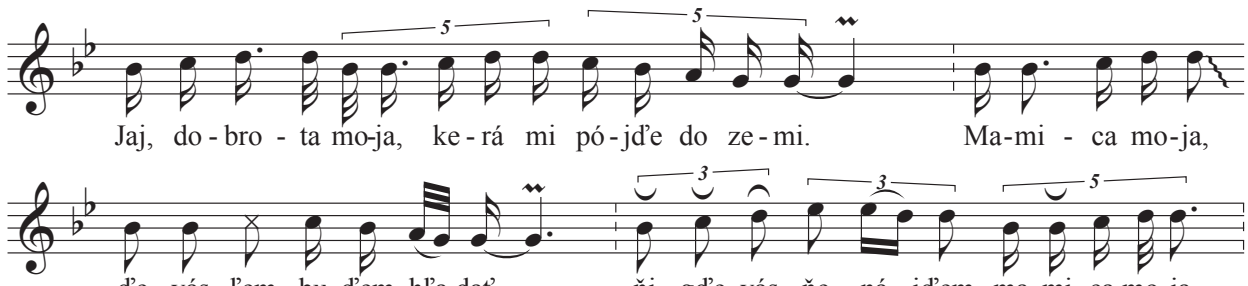

d'e vás l'em bu-d'em hl'a-dat', ňi - gd'e vás ňe - ná - jd'em, ma-mi-ca mo-ja,

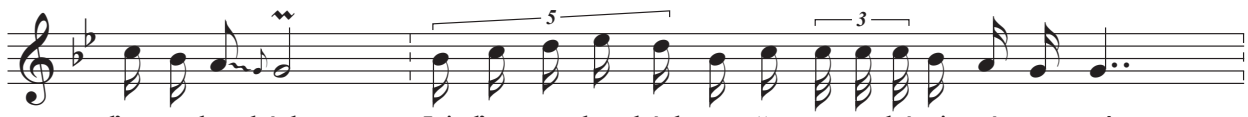

l'em na hro-bách. Jaj, l'em na hro-bách va - še me-no bó vi - pí - sa - nuô. 


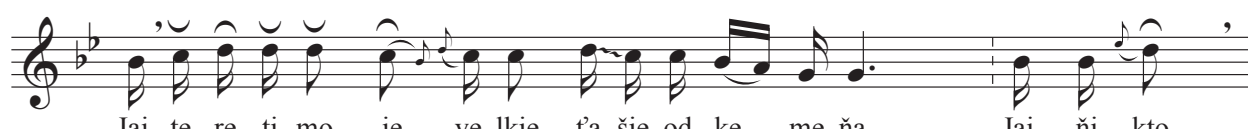

Jaj, te - re - ti mo - je, ve-lkie, t’a-šie od ke - me-ňa. Jaj, ňi - kto
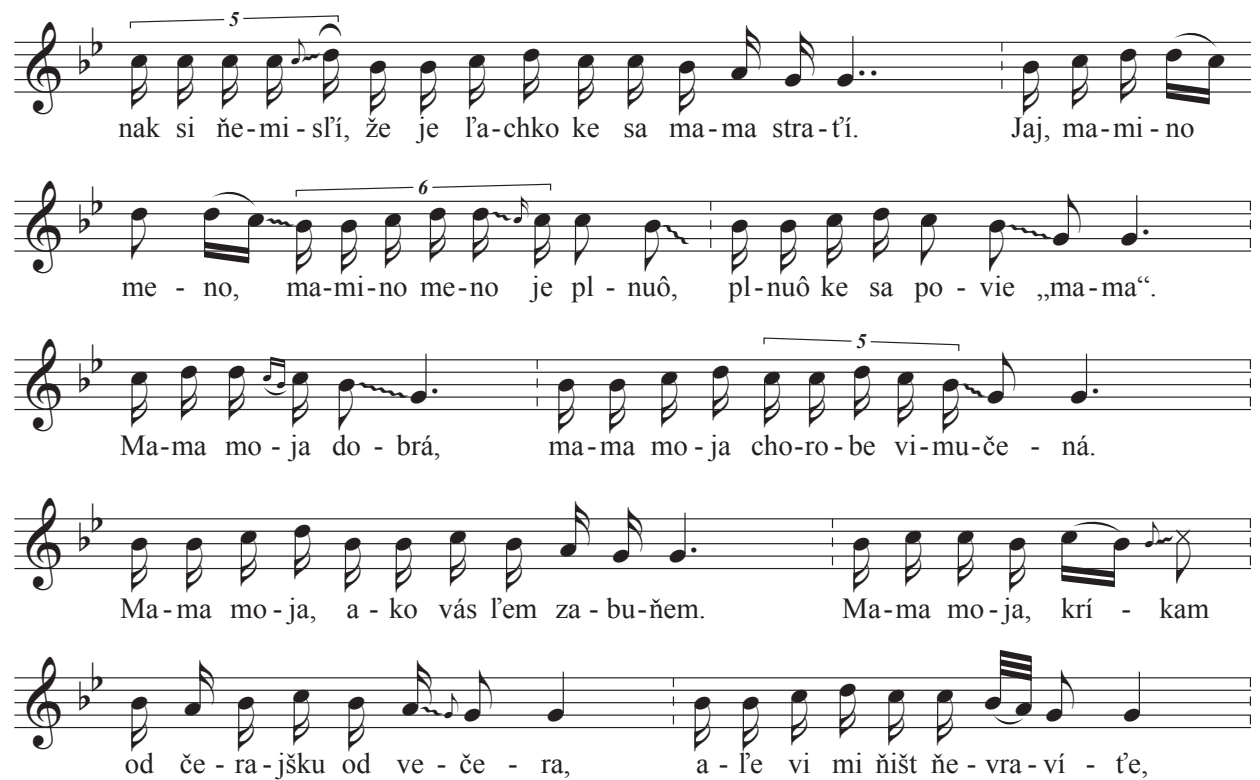

Jaj, mama moja, mamica moja, mamica moja milá, čo ste ma nahali.

Mamica moja kto mňa dočká, ke ja do tochto domu príd’em. Jaj, kto zavolá ide moja Ana. Jaj, mama moja, mamica moja. Jaj, mamica moja, ve ste sa mi chorobe namučili. Jaj, ve som vám doktora hladala aj lieke. Mama moja, ale som vám pomóste ňemohla. Mamica moja, teraz prišou doktor, kerie vám šecke bolasti aj raňi zahojiu. Mama moja, jaj, volám, kríkam, al’e vi mi ňišt ňeodhovárate.

Jaj, mamica moja ňeprežialená. Mama moja, mamica moja. Jaj, dobrota moja, kerá mi pójd’e do zemi. Mamica moja, de vás l’em bud'em hladat', ňigd’e vás ňenájd’em, mamica moja, lem na hrobách. Jaj, lem na hrobách vaše meno bó vipísanuô. Jaj, tereti moje, velkie, tašie od kemeňa. Jaj, ňikto nak si ňemislí, že je lachko ke sa mama stratí. 
Jaj, mamino meno,

mamino meno je plnuô, plnuô ke sa povie „mama“.

Mama moja dobrá,

mama moja chorobe vimučená.

Mama moja, ako vás l’em zabuňem.

Mama moja, kríkam od čerajšku od večera,

al’e vi ňišt ňevravíte, jaj, ňišt sa ňespitujete.

Mama moja, jaj aj do bolňici ke ste tašli,

mama moja, tam ste ostáli.

Koho ste lem gu sebe volali,

jaj, ke ste ňikoho svojho ňemali.

Jaj, mama moja, mama moja, mamica moja. 


\section{SUMMARY}

\section{The Embellished Singing of Slovaks in Stará Pazova (Serbia): Documentation, TransCription, ANALYSIS, INTERPRETATION}

This article addresses the issues of embellished singing in the Stará Pazova locality in Vojvodina (Serbia). It is the first work devoted to this problem which has been written on the basis of extensive field work, detailed analysis, and interpretation of its results. Previously several authors have adverted to embellished singing in Stará Pazova, but hitherto it has not been researched in greater detail. Until now, considerations on this phenomenon have concentrated above all on its possible origin. A more detailed description of this singing in connection with its occurrence, including a characterisation of the ornaments themselves and their application in delivery practice, has not been presented hitherto.

The author addresses embellished singing from several aspects. In the first chapter a survey is provided on the history of documentation of traditional singing in Stará Pazova. In most cases the older written records also document the specific embellished singing, with the oldest of these probably deriving from the early $20^{\text {th }}$ century (Benjamín Kamenár, Anton Cíger, Karol Plicka, Jozef Kresánek, Juraj Ferík sen., Ladislav Leng, Martin Kmet, Juraj Miškovic). Forming part of the historical survey is a source criticism of song records and problems of the transcription of embellished singing from the above-mentioned locality.

In her analysis of this singing, the author proceeds from her own field work conducted in 2014 (April, June, October) and 2018 (July, October, November). The source material of the article is a song corpus extending to 314 song transcriptions, of which 200 document embellished singing.

The author traces the occurrence of embellished singing in the individual music style layers, as identified in Stará Pazova's traditional song repertoire. The core of the article, in a relatively more extensive chapter, is devoted to classifying the ornaments in traditional songs in the given locality. In her classification the author proceeds from writings by several authors (Rawlins T. Joseph, Byong Won Lee, L. Leng), while drawing particularly on the works of the Hungarian ethnomusicologist Katalin Paksa. The author has distinguished 13 types of ornaments, which she more particularly describes and specifies. It has proved to be the case that embellished singing occurs most frequently in songs pertaining to an intermediate style layer of a modal character, where pentatonic songs are most numerously represented. Highlighted also is the richer representation of embellished singing in performance by men of the middle and older age categories.

This study of embellished singing has addressed the question from two aspects. The first aspect concerns the dominant linkage of embellished singing to the layer of pentatonic songs: embellished singing has been/is an established component primarily of pentatonic songs, while only occasionally making entry into the other musical style layers. This opinion is documented in specific examples by the author. The second aspect is focused on the question of the origin of embellished singing. In this connection the author returns once more to the pentatonic songs, and alongside existing hypotheses she poses a new hypothesis on the traditional songs of Slovaks from Stará Pazova. 